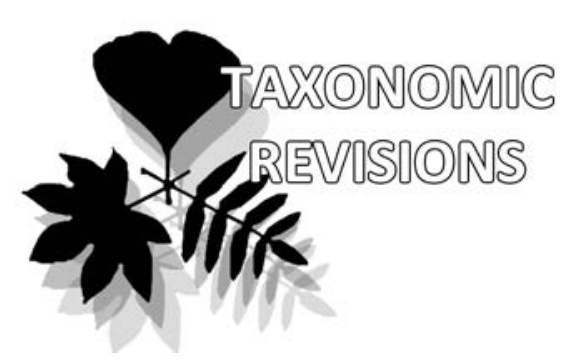

\title{
Porellaceae (Hepaticae) in the Russian Far East
}

\author{
Vadim A. Bakalin \& Ksenia G. Klimova*
}

Vadim A. Bakalin

e-mail: vabakalin@gmail.com

Ksenia G. Klimova*

e-mail: ksenia.g.klimova@mail.ru

Botanical Garden-Institute FEB RAS Vladivostok, Russia

* corresponding author

Manuscript received: 21.11.2018

Review completed: 16.02.2019

Accepted for publication: 05.03.2019

Published online: 10.03.2019

\begin{abstract}
A B S T R A C T
Porellaceae are revised for the Russian Far East. The occurrence of 11 species is confirmed; the reports of 7 more taxa are based on misidentification and these taxa are excluded from the flora. Porella obtusata var. macroloba is newly recorded for Russian Federation. The paper provides 1) descriptions and figures based on herbarium materials gathered in the Russian Far East and adjacent China, Japan and the Republic of Korea, 2) an overview of the ecology and distribution of taxa in the area treated and 3) a key to species of Porella known in the Russian Far East, species that may be expected there, and species reported from other parts of the Russian Federation.

K e y w o r d s : Porellaceae, Porella, Ascidiota, new records, taxonomy, the Russian Far East
\end{abstract}

\section{P E 3 Ю M E}

Бакалин В.А., КАимова К.Г. Porellaceae (Hepaticae) на российском Аальнем Востоке. Ревизовано Porellaceae Аля российского Аальнего Востока. Подтверждено присутствие во флоре 11 видов Porellaceae. Указания 7 видов были основаны на ошибочных определениях других таксонов и эти виды исключаются из состава флоры. Porella obtusata var. macroloba выяв еена в России впервые. В статье приводятся: 1) описания видов и рисунки, слеланные на основе гербарного материала, собранного на российском Аальнем Востоке и прилегающих территориях Китая, Японии и республики Корея, 2) экологические условия произрастания и распространение вилов в предемах российского Аальнего Востока, 3) ключ Аля определения видов Porella, уже известных и ожидаемых на российском Аальнем Востоке, а также видов, приводившихся Аля Аругих регионов России.

КАючевые слова: Porellaceae, Porella, Ascidiota, новые находки, таксономия, российский Аальний Восток
Porellaceae are characterized by large plant size and plagiotropic to ascending, rarely suberect (Frey \& Stech 2009) growth, usually 1-3-pinnate branching with Frullania-type branches, incubously inserted leaves divided into larger dorsal lobe and smaller ventral lobe, large and regular underleaves, dioicous inflorescence, obovate to ellipsoid, clearly or loosely dorsiventrally compressed perianth, short massive seta and the absence of specialized organs of vegetative propagation. The family includes 2 genera, the monotypic genus Ascidiota (not known in the Russian Far East, but likely to be found here) and the large (ca. 80 species, cf. Frey \& Stech 2009) genus Porella. Porella is distributed from boreal (very rarely occurring in Arctic and Subarctic) to tropical zones (in tropics this genus distributed in mountains, starting from the belt conditionally called as montane subtropics and above) in both the Southern and Northern Hemispheres, and is most taxonomically diverse in subtropical and tropical East Asia, where over 50 species are recorded (Hattori 1978).

In the Russian Far East, the northernmost record of Porella is from the Commander Archipelago (P. platyphylla, a circumpolar taxon) at $54^{\circ} \mathrm{N}$. The taxonomic diversity of the genus increases southward and is highest in the southernmost Primorsky Territory, where it is the third largest genus (after Scapania and Frullania) in the local hepatic flora (Konstantinova et al. 2009). The Porellaceae have never been specially studied in the Russian Far East. It seems the first data on the occurrence of this genus in area treated were provided by Lindberg (1872) who described Porella grandiloba as a new species from northwestern Sakhalin. The latter taxon is the most common species in hemiboreal and cool-temperate amphi-Pacific East Asia. The next taxon described from the Russian Far East was Madotheca ussuriensis (Stephani 1910), a synonym of Porella gracillima. Later a few records are scattered in the literature. The greatest contribution to our knowledge of Porella in the Far East was made by S. Hattori, who did not publish any paper specifically devoted to this genus in Russia, but identified a large amount of material from the former USSR and cited it in the papers united under "Studies on Asiatic species of the genus Porella" (Hattori 1967, 1970, 1978, etc.). Later he was the main 'identifier' of Porella collections gathered by S.K. Gambaryan, the first professional hepaticologist in the Soviet Far East, who sent S. Hattori most of the collections 
she could not identify. Gambaryan (1992) provides a list of 10 species of Porella (including Macvicaria that was treated as a genus separate from Porella), of which P. urophylla as synonym of $P$. gracillima, and $P$. densifolia was based on misidentifications of other taxa. Gambaryan (1992) did not provide descriptions or identification keys.

In the past 15 years, several taxa have been added to the flora (cf. Bakalin 2010), with the majority recorded by mistake (the section "Erroneous reports" of the present paper). The achievements of recent years also include the study of the type specimens for the most of the taxa, making it possible to exclude erroneously reported species and to clarify the identifications and, therefore, distribution of all the recognized taxa of the genus known in the Russian Far East. This work forms the background of the present account, which the main goal is to provide descriptions and illustrations of all recognized taxa based on domestic materials. In addition, taxa that might be expected in the Russian Far East are also included to the present treatment and all species (both recorded and expected) are keyed here to promote further investigation of this genus in Russia. The present treatment is not a treatment for all Porellaceae recorded in Russia, but it may serve to the identification of all Porella known in Russia, because only three of the species known from Russia do not occur in the Russian Far East (Porella arboris-vitae (With.) Grolle, P. baneri (Schiffn.) C.E.O. Jensen, P. cordaeana (Huebener) Moore), and these taxa are included in the identification key, although not treated in detail. Descriptions in this paper are based entirely on specimens examined. The specimens examined sections do not include citations of duplicates and they cite only one specimen per locality. In total, 412 specimens are cited in this paper. The majority of them are in VBGI, and secondly in KPABG.

\section{TAXONOMIC TREATMENT Key to Porellaceae genera known or expected in the Russian Far East}

1. Leaf dorsal lobe margin more or less ciliate, bases of both lobes and underleaves with water-sacs, dorsal surface of leaf dorsal lobe coarsely verrucose, with one large dome-like verrucaaboveeachcell.. [not known, but probable in the North-East Asia]

2. Leaf dorsal lobe margin entire to dentate, rarely ciliate, specialized water sacs absent in leaf lobes and underleaves, dorsal surface of the dorsal lobe smooth to weakly papillose, never with dome-like verrucae above each leaf cell .......

Porella

Ascidiota C. Massal., Nuovo Giorn. Bot. Ital. (n.ser.) 5 (2): 256, 1898.

[a monotypic genus, discussed under the species]

Ascidiota blepharophylla C. Massal., Nuovo Giorn. Bot. Ital. (n. ser.) 5(2): 257, 1898 (including Ascidiota blepharophylla subsp. alaskana Steere et R.M.Schust., Bull. Torrey Bot. Club 87 (3): 213, 1960). Fig. 1-8

Before 2015 (Potemkin et al. 2015), the species was regarded as Sino-Hymalayan - Alaskan disjunct, although it was expected in northern Asia by Schljakov (1982). Potemkin et al. (2015) described two additional localities of
Ascidiota in Siberia (Yuzhno-Muisky Range in South Siberia and the upper course of the Ereechka River in the northern periphery of the Central Siberian Plateau). The latter confirms Schljakov's (1982) expectations and makes it more likely that it could be found in the northern part of the Russian Far East.

Steere \& Schuster (1960) treated Alaskan plants as subspecies alaskana, distinct from the type subspecies blepharophylla. Later, however, Steere \& Inoue (1978) concluded that the differences between Alaskan and Chinese plants are not sufficient to maintain subspecific status for the Alaska populations. The latter point of view was adopted by Potemkin et al. (2015), although these authors (l.c.) indicated that the material available to them is not sufficient to make this conclusion without doubts. With the same proviso we follow here to treatment of infraspecific structure of the species as suggested by Steere \& Inoue (1978). Since an exhaustive description and discussion of the taxon were published recently by Potemkin et al. (2015) it seems unnecessary to repeat them here. However, we provide a figure (Fig. 1) of this taxon, prepared from the paratype of $A$. blepharophylla ssp. alaskana (W.C. Steere 16863) now deposited at F (c0070164f, kindly loaned to MO in 2012).

\section{Porella L., Sp. Pl. 1: 1106, 1753.}

Description. Plants ${ }^{1}$ prostrate to ascending, rarely erect in dense patches, forming pure mats or, more rarely, growing mixed with other hepatics (including other species of Porella) or mosses, 5-20 and more $\mathrm{cm}$ long and 1.2$4.0 \mathrm{~mm}$ wide. Stem more or less rigid, rarely soft in some taxa, brownish to brown, rarely greenish to yellowish green, sparsely to irregularly or regularly pinnately to bi- or tripinnately branched, branches of Frullania type. Rhizoids few or none, if present then in short, obliquely to erect spreading brownish to brown fascicles originating at underleaf bases. Leaves divided into a larger dorsal lobe and a smaller ventral lobe; dorsal lobes obliquely incubously inserted, mostly imbricate, ovate to obliquely ovate or rounded, lobe apex rounded to acute, apiculate and shortly bidentate, lobe margin smooth to variously toothed or (rarely) ciliate; ventral lobe oblong, oblong-ovate to triangular (sometimes narrowly so), arcuately inserted, variously decurrent (rarely not or barely decurrent), apex rounded to acute and bidentate, ventral lobe margin entire to variously toothed. Underleaves regular, prominent, wider than stem, commonly short or long decurrent, rarely not decurrent, widely ovate to narrowly triangular, apex rounded to acute and bidentate, underleaf margin entire to variously toothed. Cells in dorsal lobe middle thin-walled, rarely walls slightly thickened, trigones small, concave, rarely moderate in size; cells along dorsal lobe margin thin- to thick-walled. Dioicous. Androecia spicate, on lateral branches, rarely on the main stem, terminal, uniandrous. Gynoecia terminal on lateral branches, without subfloral innovations; perianth strongly or weakly dorsiventrally compressed, sometimes somewhat trigonous with a weak ventral plica or 5-plicate in some taxa, mouth dentate to shortly lobulate, sometimes distinctly bilabiate.

\footnotetext{
1 The description includes charaters known in taxa reported or expected in the Russian Far East.
} 

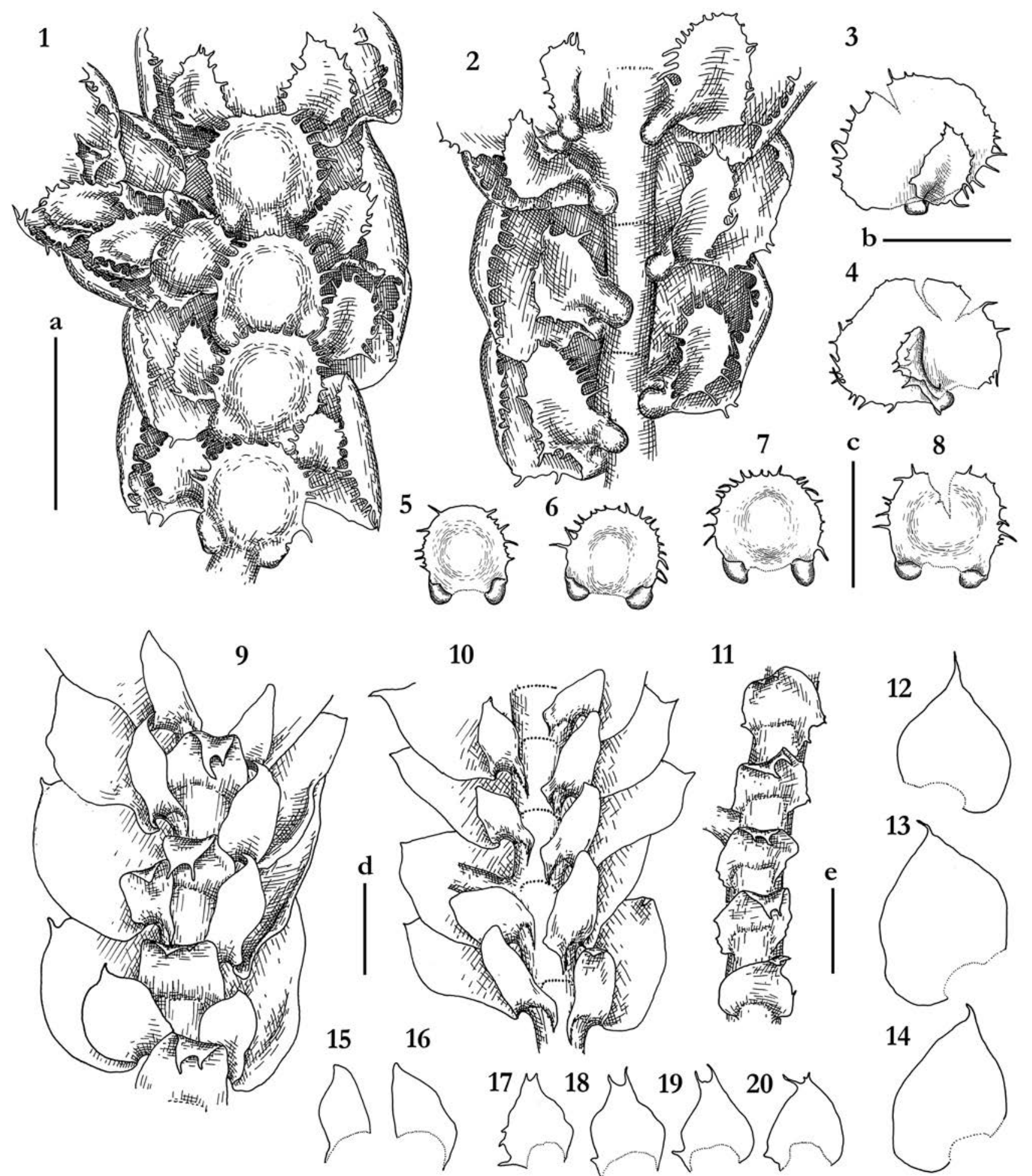

10

11
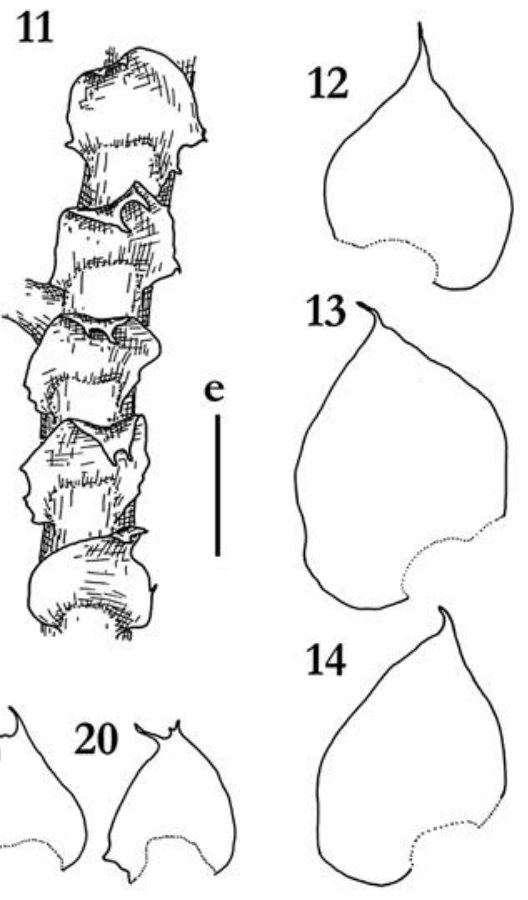

Figure 1 Ascidiota blepharophylla C. Massal: 1 - plant habit, fraoment, ventral view; 2- plant habit, fraoment, ventral view, underleaves detached; 3, 4-leaves; 5-8 - underleaves. Scales: a - $1 \mathrm{~mm}$, for 1, 2; b - $1 \mathrm{~mm}$, for 3, 4; c-1 mm, for 5-8 (all from Steere 16863 (c0070164f), F). Porella caespitans (Steph.) S. Hatt.: 9 - plant habit, fragment, ventral view; 10 - plant habit, fragment, ventral view, underleaves detached; 11 - plant habit, fragment, ventral view, leaves detached; 12-14 - dorsal lobes; 15, 16 - ventral lobes; 17-20 - underleaves. Scales: $\mathrm{d}-1 \mathrm{~mm}$, for 9-11; e $-1 \mathrm{~mm}$, for 12-20 (all from P-74-31-11, VBGI)

Seta massive and short. Capsule emergent from the perianth or fully immersed. Spores multicellular at maturity, papillose; elaters 1-3-spiral. Specialized organs of vegetative reproduction not known.

Comments. The genus is one of the 'oldest' genera of hepatics that is easily to recognize in the field even with the naked eye due to its relatively large size and imbricate (or nearly so) incubously oriented dorsal lobes. Among regional genera, confusion is only and very hardly possible with large Bazzania or Frullania. Southward of the area treated here, several genera of Lejeuneaceae may be mistaken in the field for Porella. Large plants of Frullania always have a distinctly cucullate or saccate ventral lobe (strikingly defined as the 'median lobe', because the third lobe in Frullania is strongly 
reduced and called the stylus). On the other hand, Barzania has no ventral lobe at all, but often has many geotropic flagellae with scale-like leaves, a feature that is never seen in Porella.

The main diversity of Porella is south of the Russian Far East, and many of our species are confined to the southern flank of our area. The Porella species known here show a meso- to xerophytic nature, with the exception of $P$. platyphylla that may be observed in temporarily inundated stream beds. The most common habitat for Porella in the Russian Far East are stones, rock outcrops and trunk bases in hemiboreal to temperate communities; other habitats are much rarer. Currently, 11 species of Porella are recorded in the Russian Far East, 1 more species could be expected and 3 more are known from other parts of Russia. All are included in the key below. The identification key is based on vegetative characteristics because generative organs are rarely observed in Porella. Most of the key uses morphological characteristics, with the exception of a chemotaxonomic feature of the plant, a reaction with a solution of iodine and potassium iodide in alcohol (IKI-reaction). The best way to perform this reaction is to put a shoot fragment into a drop of water on the slide and carefully add a small drop of iodine solution commonly used for medical treatment (this always contains traces of potassium iodide). If the reaction is positive, the area treated turns a bright violet-black. If the reaction is negative, only a light yellowing will be seen. This method may be used not only for recent collections, but also for specimens even 100 and more years old.

\section{Key to species of Porella recorded and expected in the Russian Far East and taxa known in other parts of the Russian Federation}

1. Dorsal leaf lobe with a prominently attenuate-acute apex, entire or dentate in apical part Porella caespitans

1. Dorsal leaf lobe with the apex rounded to obtuse, entire or variously toothed, never attenuate-acute, at least in the leaves distant from female bracts

2. Dorsal leaf lobe dentate, 1 -several short teeth are present at least in apical part in $50 \%$ of leaves

2. Dorsal leaf lobe entire near apex

3. Dorsal leaf lobes densely toothed throughout (with the exception of depauperate plants where leaf lobes may be entire or nearly so) ................................................................. 4

3. Dorsal leaf lobes sparsely toothed, with teeth mostly confined to the lobe apex .......................................................... 6

4. Underleaves of well-developed shoots suborbicular to transversely elliptic, toothed throughout, teeth longer in apical part Porella faurieri

4. Underleaves of well developed shoots triangular with a truncate apex, teeth longer near the underleaf base, absent or short near apex ...................................................................... 5

5. Cells in dorsal lobe middle 19-27 $\mu \mathrm{m}$ wide, oblong, about $50 \%$ of leaf lobes in well developed shoots (wider $2.0 \mathrm{~mm}$ ) with the apex entire

Porella spinulosa

5. Cells in dorsal lobe middle 12-22(-25) $\mu \mathrm{m}$ in diameter, subisodiametric, all leaves of well developed shoots densely toothed

Porella vernicosa

6. Leaf dorsal lobes oblong lingulate, with a truncate and sparsely toothed apex, ventral lobes lingulate to oblong-rec- tangular, cells in dorsal lobe middle (22-)25-32 $\mu \mathrm{m}$ in diameter

Porella oblongifolia

6. Leaf dorsal lobes ovate to triangular-ovate, apex obtuse to rounded, toothed or not, rarely narrowly truncate (in generally triangular leaf dorsal lobes), ventral lobes ovate to oblong ovate, cells in dorsal lobe middle $15-25 \mu \mathrm{m}$ in diameter …

7. Plants notglossy, underleaves decurrent for 1.0-1.5 of stem width, entire or toothed only near the apex, leaf dorsal lobes ovate-triangular.............................................Porella densifolia [an East Asian taxon, not known in the Russian Far East, but possible there]

7. Plants glossy, underleaves decurrent for $0.2-1.5$ of stem width, entire to dentate, leaf dorsal lobes ovate .................... 8

8. Ventral leaf lobe densely toothed throughout, commonly undulate-crispate near the ventral base [East Asian]

Porella spinulosa

8. Ventral leaf lobe entire or nearly so, rarely toothed (mostly on stems close to gynoecia), lobes never undulate-crispate nearventral base [mostly European (eastward to CaspianSea)North African, notknownin East Asia]

Porella arboris-vitae description and illustrations: Paton, 1999, Damsholt, 2002]

9. IKI reaction positive 10

9. IKI reaction negative 11

10. Cells in dorsal lobe middle $17-28 \mu \mathrm{m}$ in diameter, female bracts entire or with 1-2 obtuse teeth on dorsal margin ......... Porella platyphylla

10. Cells in dorsal lobe middle $38-40 \mu \mathrm{m}$ in diameter, female bracts dentate [not known in East Asia, the taxon of uncertain taxonomicstatus, knownin Russia from the Caucasus]

[Porella baueri the discussions on status are in: Paton 1999, Damsholt 2002]

11. Ventral leaf lobe decurrent for (0.5-)0.7-2.0 of stem

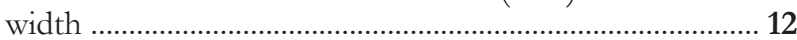
11. Ventral leaf lobe not, barely or shortly (to 0.5 of stem width) decurrent

12. Plants glossy, cells in dorsal lobe middle $10-20(-25) \times$ 8-20(-25) $\mu \mathrm{m}$, plants with peppery taste

Porella gracillima

12. Plants not glossy, cells in dorsal lobe middle (22-)25-43 $\times(22-) 25-38 \mu \mathrm{m}$, plants \pm tasteless ..................................... 13

13. Leaves in well developed plants strongly crispate-undulate along margin, rhizoids (when present) mostly brown to rusty brown in color, ventral leaf lobes of various shapes, well developed ventral lobes mostly slightly longer than wide

Porella ulophylla

13. Leaves never crispate-undulate along margin, rhizoids (when present) mostly brownish, ventral leaf lobes longer that wide or wider than long

14. Ventral leaf lobes 1.5-2.0 times longer than wide, oblong ovate to lingulate, underleaves 1.5-2.5 times wider than stem

Porella chinensis

14. Ventral leaf lobes triangular, as wide as long or wider than long, underleaves as wide as stem or to 1.5 times wider than stem [the subcircumpolarly distributed taxon, not known in area treated, but recorded in South Siberia and thus may be expected the Far East]....... [Porella cordaeana description and illustrations: Schljakov 1982, Paton 1999, Damsholt 2002]

15. Leaf dorsal lobes absolutely entire (rarely loosely crispate near bases, but never toothed), underleaves not or to 
$1 / 4(-1 / 3)$ of stem width decurrent, ventral leaf lobes and underleaves entire along the whole margin, including the basal part.

Porella grandiloba

15. Leaf dorsal lobes sparsely toothed (at least some well developed leaves toothed near apex), underleaves decurrent for 0.5 or more of the stem width, ventral leaf lobes and underleaves commonly toothed in the basal part or above ...

16

16. Plants not glossy, dorsal leaf lobe widely triangular to triangular-ovate, sometimes with a truncate and sparsely toothed apex, plants \pm tasteless ................. Porella densifolia

16. Plants somewhat to distinctly glossy, dorsal leaf lobe ovate, apex rounded, sometimes with a prominent tooth in its uppermost part, plants taste-less or not. 17

17. Underleaves coarsely dentate, dorsal lobe apex entire or with prominent teeth, plants with peppery taste [not known in East Asia] ........................................ [Porella arboris-vitae description and illustrations: Paton 1999, Damsholt 2002]

17. Underleaves entire (although commonly undulate at the margin), dorsal lobe apex rounded, plants \pm tasteless ....

Porella obtusata var. macroloba

Porella caespitans (Steph.) S.Hatt., J. Hattori Bot. Lab. 33: 50, 1970. Fig. 1:9-20

Madotheca caespitans Steph., Mém. Soc. Nat. Sci. Nat.

Math. Cherbourg 29: 218, 1894.

Porella caespitans var. setigera (Stephani) S. Hatt., J.

Hattori Bot. Lab. 33: 53, 1970.

Porella setigera (Stephani) S. Hatt., J. Jap. Bot, 20: 107, 1944.

Description. Plants prostrate to ascending, rarely erect in dense patches, yellowish brown and brownish green to deep green or yellow-green, slightly glistening, 50-200 $\times$ 2.5-3.5 mm. Stem brownish to brown or yellowish green, regularly pinnately or bipinnately branched, 300-500 $\mu \mathrm{m}$ wide. Rhizoids virtually absent. Dorsal leaf lobes imbricate (then covering 1/4-1/3 of the next most distal dorsal lobe) to, more rarely, contiguous, $1.2-1.8 \times 1-1.6 \mathrm{~mm}$, dorsally arcuately inserted and barely decurrent, entire to crispate, rarely with a few obtuse teeth near base, margin entire to loosely crispate, apex acuminate, with margin entire or with 1-several short and obtuse to prominent additional subapical teeth, when flattened on the slide obliquely ovate. Ventral leaf lobes slightly concave-canaliculate, obliquely spreading or loosely deflexed away from the stem, oblong to oblong triangular, oblong ovate and ovate-triangular, 0.6-1.1 $\times$ $0.3-0.7 \mathrm{~mm}$, decurrent for $0.7-1.5$ of stem width, rarely continuing as short row of paraphyllia-like structures, commonly with 1-several small (rarely prominent) teeth on the decurrency, rarely tapered lingulate, with acute to obtuse or shortly bilobed apex, entire and rarely slightly revolute along margin. Underleaves mostly squarrose, sheathing the stem near base and deflexed above, decurrent for 1.0-1.5 of stem width on both sides, bilobed near apex, lobes prominently acuminate with 2-5-celled uniseriate apices, $0.6-1.0 \times 0.3-$ $0.9 \mathrm{~mm}$, mostly entire, sometimes narrowly revolute along underleaf body margin, near base (in decurrent area) commonly obscurely toothed or angular-crispate. Cells in dorsal lobe middle $17-35 \times 15-25 \mu \mathrm{m}$, subisodiametric to shortly oblong, thin-walled, trigones moderate in size, triangular to slightly convex; cuticle smooth; oil bodies in the dorsal lobe middle 15-30 per cell, homogenous, spherical to elliptic,
2.5-5.0 $\times 2.5-3.0 \mu \mathrm{m}$. Androecia terminal on branches of the first or second order, with 1-several pairs of sterile leaves between branch origin and antheridial bracts, spicate, with 3-8 pairs of bracts, monoandrous. Gynoecia not seen, described from Japanese plants by Hattori (1970).

Variation. The greatest variation is observed in the dentation of the apical portion of the dorsal leaf lobe. In most cases the apical part of the lobe is prominently acute, but otherwise completely entire. However, very vigorous plants or plants from humid habitats sometimes bear additional subapical teeth. Due to the latter feature, and minor differences in dorsal lobe shape, several varieties could be recognized within this species (var. setigera, var. nipponica, var. cordifolia). However, these varieties seem to be only environmentally induced modifications, so we follow to Konstantinova et al. (2009) and do not recognize any taxa of subspecific rank.

Differentiation. This is the only regional taxon that characterized by a prominently acuminate leaf apex with subapical teeth absent or much smaller than the acuminate apex. A slightly glistening appearance, and deflexed underleaves that are divided into two acute to apiculate lobes, are other identification features that permit recognition of the species. Porella tosana (mistakenly recorded for several times for Russia) is very remotely similar to $P$. caespitans. The latter differs from $P$. caespitans in its obtusely triangular lobe apex (versus prominently apiculate-acute in $P$. caespitans) that is densely toothed with some teeth reaching 2/3-1 of terminal tooth (versus additional teeth, if present, much shorter than the terminal tooth).

Ecology. Indifferent meso-xerophyte. The most 'xerophilous' taxon of the genus in our area. Occurring over rocky substrata of various chemical composition, from andesite tufa to pure limestone. More rarely occurs on the bases and trunks of broadleaved trees. The species prefers partly shaded habitats (it is also common in open habitats, but avoids full sun) in multidominant broadleaved and Manchurian mixed forests, and rarely in pure Quercus forests. Southward of our area (in Japan and the Korean Peninsula) it become more common on tree trunks than in the Russian Far East and commonly grows in evergreen forests. In the Russian Far East the species forms pure mats or grows with Frullania taradakensis Steph., Metrgeria pubescens (Schrank) Raddi, Porella gracillima, P. ulophylla, P. vernicosa. In the Russian Far East this species occurs at the some distance from the sea coast, preferring lowlands (or stream valleys at elevations to $500 \mathrm{~m}$ a.s.l.). There are only two exceptions, where the taxon grows on the top of low mountains: both are in the East Manchurian Mountains (Sinyaya Mt. - $607 \mathrm{~m}$ a.s.l. and Sukhorechensky Range $-500 \mathrm{~m}$ a.s.l.). The species is regularly found in such habitats on the Korean Peninsula, where the localities of the taxon lie between 200 and $800 \mathrm{~m}$ a.s.l.

Distribution. The species is distributed in East, SouthEast and South Asia. It seems to be the southernmost element among our Porella taxa as well as the liverwort flora of the Russian Far East in general. Most localities in the Russian Far East lie south of $45^{\circ} \mathrm{N}$, with two isolated records northward: in Bolshekhekhtsirsky State Nature Reserve at $48^{\circ} \mathrm{N}$ and Anyui River valley at $49^{\circ} \mathrm{N}$ (Fig. 2:1). 
Porella chinensis (Steph.) S.Hatt., J. Hattori Bot. Lab. 30: 131, 1967. Fig. 3:1-15

Madotheca chinensis Steph., Mém. Soc. Nat. Sci. Nat.

Math. Cherbourg 29: 218, 1894.

Description. Plants prostrate, green, deep green to brownish green, 50-200 × 1.5-3.8 mm. Rhizoids virtually absent, sometimes present in depauperate branches when such a branch touches the substrate, brown to pale rusty. Stem brownish, brown and greenish brown, freely and regularly pinnately and bipinnately branched, $300-400 \mu \mathrm{m}$ wide. Dorsal leaf lobes imbricate (then covering $1 / 3-1 / 2$ of next most distal dorsal lobe) or, more rarely, contiguous, convex, when dry distinctly incurved to ventral side, obliquely ovate, ovate to lingulate-ovate, with triangular upper third and shortly rounded apex, 1.2-1.3 × 1.1-1.2 mm, shortly (rarer to $1 / 2$ of stem width) decurrent dorsally, margin plane or slightly undulate, in ventral base sometimes loosely involute, entire to loosely crispate (sometimes obviously crispate near dorsal base, rarely with a few (1-5) large obtuse teeth near dorsal base). Ventral leaf lobes canaliculate, sometimes slightly undulate and/or revolute along margin, very narrowly spreading, subparallel to the stem, ovate to triangular ovate, $0.6-1.1 \times 0.4-0.6 \mathrm{~mm}$, decurrent for $0.7-1.5$ of stem width, entire to loosely crispate or loosely and remotely obtusely dentate, but commonly with large and mostly obtuse teeth in decurrencies, continuing as paraphyllia like structures. Underleaves slightly to noticeably decurved, decurrent to $1.0-1.5$ of stem width, ovate, with rounded to truncate apex, $0.5-0.8 \times 0.6-0.8 \mathrm{~mm}$, commonly crispate along margin, rarer with obtuse teeth in lateral sides, become coarsely crispate or obtusely dentate in decurrent area. Cells in dorsal lobe middle $22-43 \times$
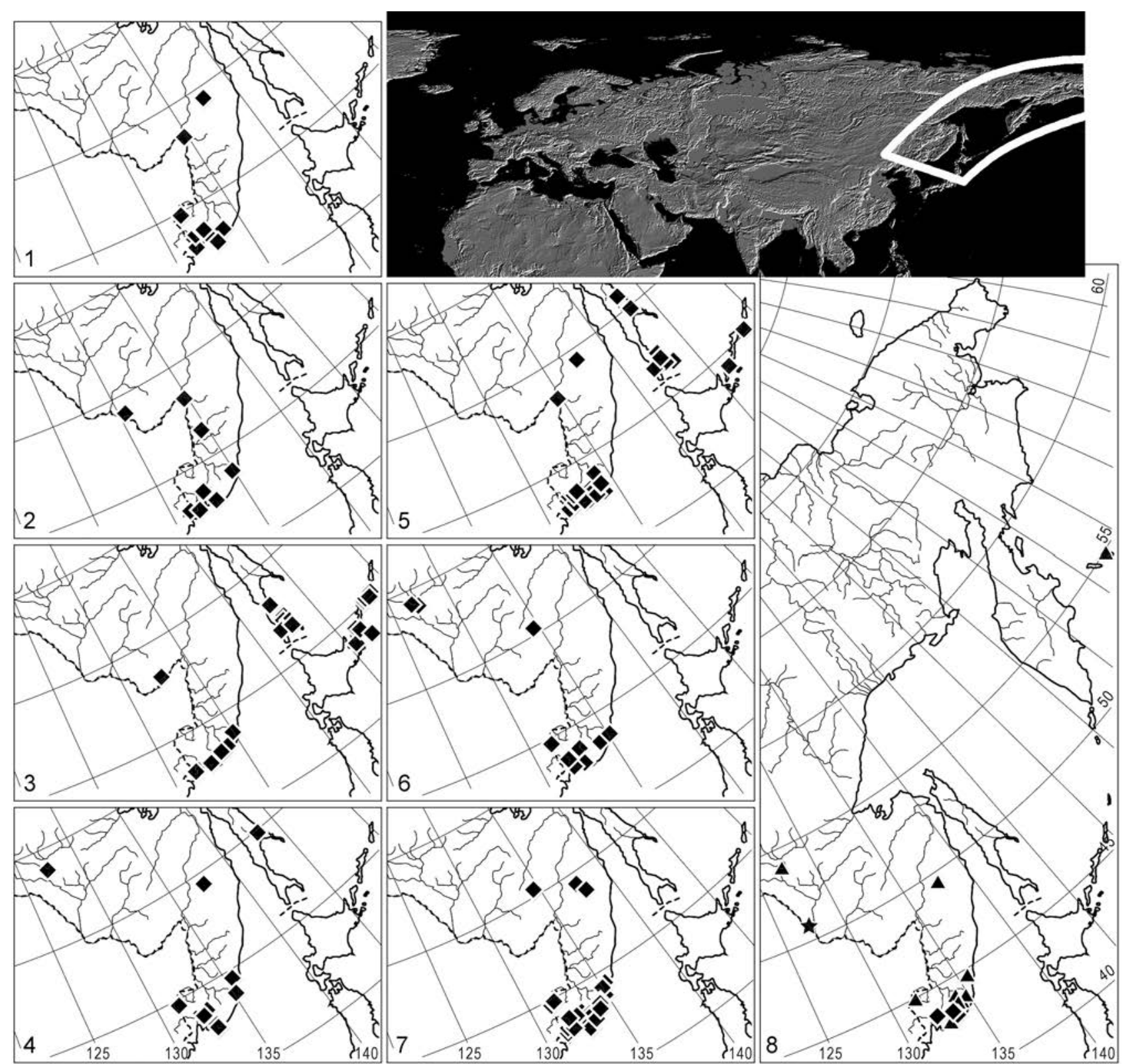

Figure 2 The distribution of Porella taxa in the Russian Far East: 1 - P. caespitans (Steph.) S. Hatt.; 2 - P. chinensis (Steph.) S.Hatt.; 3 - P. faurieri (Steph.) S. Hatt.; 4 - P. gracillima Mitt.; 5 - P. grandiloba Lindb.; 6 - P. ulophylla (Steph.) S. Hatt.; 7 - P. vernicosa Lindb.; 8 - P. oblongifolia S. Hatt. (rhombuses), P. obtusata var. macroloba (Steph.) S. Hatt. \& M.X. Zhang (asterisk), P. platyphylla (L.) Pfeiff. (triangles) 

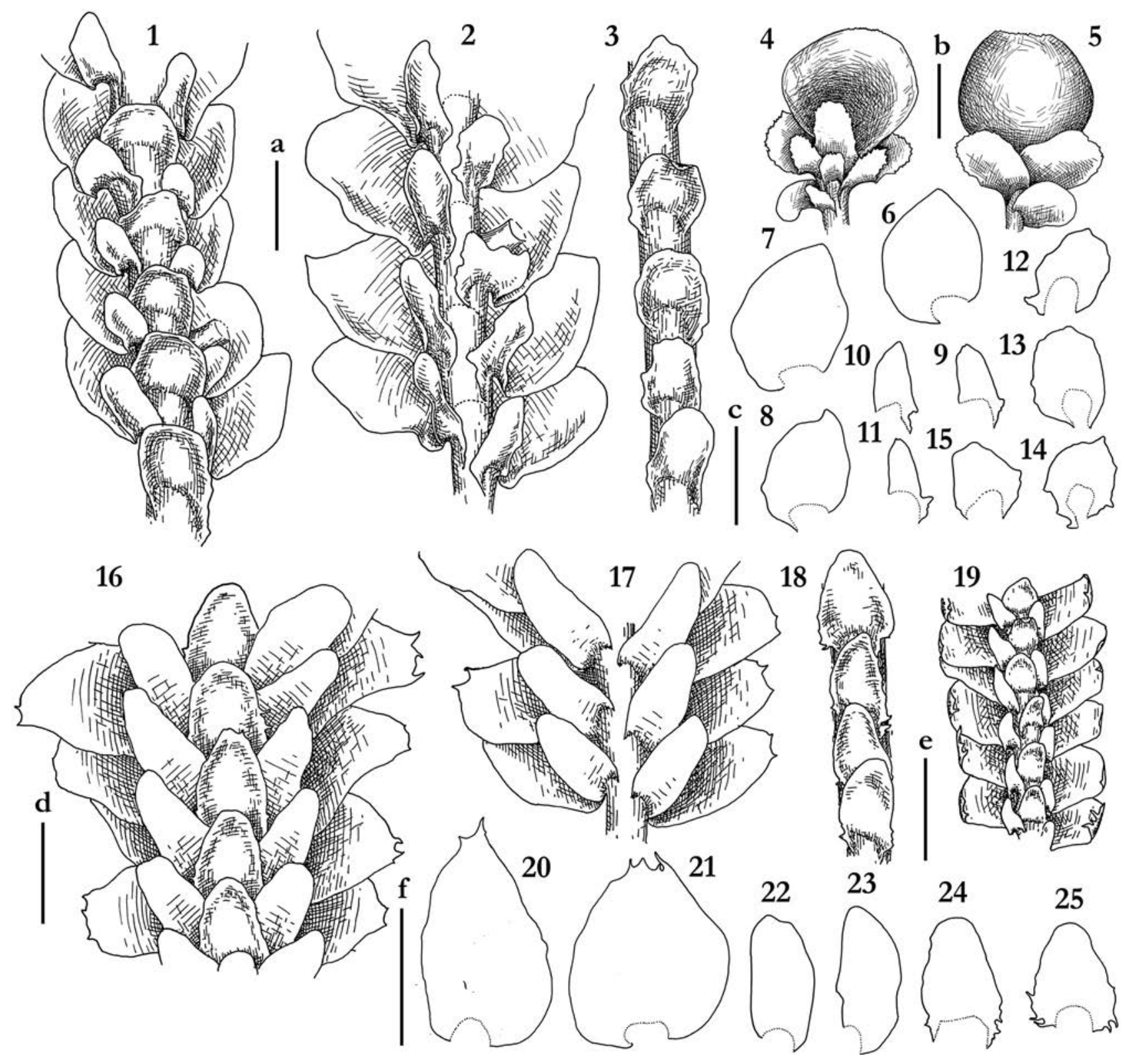

Figure 3 Porella cbinensis (Steph.) S.Hatt.: 1 - plant habit, fragment, ventral view; 2- plant habit, fragment, ventral view, underleaves detached; 3 - plant habit, fragment, ventral view, leaves detached; 4 - perianth, ventral view; 5 - perianth, dorsal view; 6-8 - dorsal lobes; 9-11 ventral lobes; $12-15$ - underleaves. Scales: $\mathrm{a}-1 \mathrm{~mm}$, for $1-3$; b - $1 \mathrm{~mm}$, for 4, 5; c - $1 \mathrm{~mm}$, for $6-15$ (1-3, 6-15 from P-85-2-07; 4, 5 from Gambaryan, 18.VI.1991, VBGI). Porella densifolia (Steph.) S.Hatt.: 16, 19 - plant habit, fragment, ventral view; 17 - plant habit, fragment, ventral view, underleaves detached; 18 - plant habit, fragment, ventral view, leaves detached; 20, 21 - dorsal lobes; 22, 23 - ventral lobes; 24, 25 - underleaves. Scales: $\mathrm{d}-1 \mathrm{~mm}$, for 16-18; e - $1 \mathrm{~mm}$, for 19; f - $1 \mathrm{~mm}$, for 20-25 (16-18, 20-25 from J-7-8-13; 19 from J-4-4-15, VBGI)

22-38 $\mu \mathrm{m}$, more or less thin-walled, trigones moderate in size, rarely large, triangular to slightly concave or convex, rarely strongly convex; cells along lobe margin commonly with thickened walls. Androecia terminal on branches of the first or the second order, with 0-1 pairs of sterile leaves between branch origin and antheridial bracts, spicate, with 5-12 pairs of bracts, sometimes branched (branches are also androecious), bracts subequally bilobed. Gynoecia on short lateral branches of the first or the second order; perianth dorsiventrally compressed, juvenile perianth with unfertilized archegonia and just after fertilization curved to ventral side, nearly rounded in the projection, 1.8-2.2 $\times$ 1.8-2.2 mm, apical part truncate, mouth dentate with sparse prominent teeth composed by 2-6 uniseriate subquadrate cells. Capsule hidden within perianth or exerted for less than $1 / 5$ of its length.

Variation. Within the Russian Far East this species is not very variable, although some depauperate phases bear ventral leaf lobes only 1.2-1.3 times as long as wide. These phases may be misidentified as $P$. platyphylla (see discussion under that species). The cell wall thickness along dorsal leaf lobe margin may also vary. The species was originally described from mountains in Yunnan (3500 $\mathrm{m}$ a.s.l.). The type of the species (under Madotheca chinensis) is in G (G00043966/12601). It is similar to Russian plants in habit, but it has uniformly thin-walled cells along the dorsal leaf 
lobe margin. However, the plants in the specimens from the Russian Far East have uniformly thickened cell walls along the dorsal lobe margin.

Differentiation. The species is most closely related to Porella platyphylla. Both taxa may be easily differed by the IKI reaction, which is always negative in $P$. chinensis, but positive (at least in vast majority of specimens) in P. platyphylla. Another differentiating feature is the ventral lobes that are 1.62.0 longer than wide in $P$. chinensis, versus less than 1.5 times longer that wide in P. platyphylla. The feature of decurrent dorsal lobe (mentioned in literature, cf. Hattori 1978) is not so stable because some depauperate phases of $P$. chinensis have the dorsal base not or scarcely decurrent. Another superficially similar species is $P$. ulophylla that in most cases differs in its strongly undulate dorsal lobe margin. However, in weak phases the crispate-undulate nature of the leaf margin may not be evident. Both taxa are also characterized by a negative IKI reaction. The differentiation of sterile material in the latter case may be based on relatively long ventral lobes in P. chinensis, whereas well developed ventral lobes of P. ulophylla are less than 1.5 times as long as wide; besides P. ulophylla commonly has brown rhizoids versus pale brownish in common phases of $P$. chinensis. However, in some cases the identification of poorly developed plants from shady habitats may remain doubtful.

Ecology. Acidophilic to neutro-tolerant mesophyte. More xerophytic and probably more acidophilic than P. platyphylla. Occupying mesic to dry, mostly partly shaded trunk bases and cliffs. Sparsely occurring in Manchurian mixed forests, rarer in floodplain communities and oak secondary forests with Lespedeza understory. This is a low elevation taxon, with the highest locality in Lozovyi (Chandolaz) Range in the southern Primorsky Territory. The type of the species is from high altitude Yunnan in southern China.

Distribution. The taxon is probably of meta-Himalayan distribution, known in the spurs of Himalaya in China and spreading to the North-East as far as to the southernmost portions of the Russian Far East. It is not known from Japan or the Korean Peninsula. This species is at the north-eastern limit of its area in the Russian Far East. It is sparsely distributed on the western slope of the middle and southern Sikhote-Alin Mts., occuring east of this only in the Lozovyi (Chandolaz) limestone range; northward known in the Khingansky and Bol'shekhekhtsirsky State Nature Reserves (49 and $48^{\circ} \mathrm{N}$ respectively). Most of the records provided by Gambaryan (1992) belong to other species (in most cases underdeveloped Porella platyphylla and P. grandiloba (Fig. 2: 2).

Porella densifolia (Steph.) S. Hatt., J. Jap. Bot. 20: 109, 1944. Fig. 3:16-25

Madotheca densifolia Steph., Mém. Soc. Nat. Sci. Nat. Math. Cherbourg 29: 219, 1894.

Description. Plants not glossy, deep brownish green, yellowish brown in the herbarium, 40-80 × 2.2-3.6 mm. Rhizoids virtually absent, rarely present, in short erect spreading brownish fascicles 200-300 $\mu \mathrm{m}$ long. Stem freely pseudodichotomously or pinnately branched, $300-400 \mu \mathrm{m}$ in diameter, brown to brownish. Dorsal leaf lobes imbricate, slightly convex, rarely loosely canaliculate near apices, obliquely ovate (if apex narrowly rounded) to ovate-triangular (if apex dentate), entire at lateral sides, 1.2-1.5 × 1.0-1.4 $\mathrm{mm}$, dorsally arcuately inserted, not or barely decurrent with lobe apices rounded and also entire or narrowly truncate to obtuse and dentate, with $2-5$ short teeth, the largest teeth on sterile leaves $4 \times 3$ cells. Ventral leaf lobes in the same plane as dorsal leaf lobes, laterally obliquely spreading, ovate-lingulate (commonly narrowly so), entire throughout, $0.6-1.0 \times 0.4-0.7 \mathrm{~mm}$, arcuately inserted, barely or to $1 / 4$ of stem width decurrent, with rounded apex or crispate to obtusely angular near base. Underleaves appressed to the stem and then overlapping lower part of next most distal underleaf or slightly deflexed in apical part of shoot, ovate to ovate-triangular, apex rounded, margin entire to loosely crispate and angular near base (especially in its decurrent part), $0.6-0.9 \times 0.5-1.1 \mathrm{~mm}$, decurrent for $1 / 2-3 / 2$ of stem width. Cells in dorsal lobe middle subisodiametric, 15$25 \mu \mathrm{m}$ in diameter, thin-walled, trigones moderate in size, concave to triangle, cuticle smooth; cells along dorsal lobe margin with slightly to evidently and evenly thickened walls, 10-15 $\mu \mathrm{m}$ along margin, cuticle smooth (Fig. 3). Gynoecia not seen, described and illustrated by Hara (1956).

Differentiation. This is a very polymorphous taxon, especially in the leaf lobe features. In some phases the dorsal leaf lobe apices are rounded whereas in others they are obtuse with several teeth. Both types of leaves may be seen on the same plant. Ventral lobes are relatively large with a rounded apex and shortly decurrent, and underleaves are long decurrent with a rounded apex. Porella platyphylla differs from $P$. densifolia in its always entire lobe apex, long decurrent ventral leaf lobes, larger cells in lobe middle and positive IKI reaction.

Distribution. Generally an East Asian species (with two subspecies known from India). In areas adjacent to the Russian Far East $P$. densifolia is known in Japan (where locally abundant) and is sparsely distributed in Korean Peninsula. It is not known in North-East China (cf. Piippo 1990). The occurrence of species in the Russian Far East is not confirmed.

Porella faurieri (Steph.) S.Hatt., J. Jap. Bot. 20: 109, 1944. [,fauriana"]. Fig. 4:1-13

Madotheca faurieri Steph., Sp. Hepat. (Stephani) 4: 315, 1910.

Porella vernicosa subsp. fauriei (Steph.) M. Hara, Res. Rep. Kôchi Univ. 4(12): 26, 1956.

Description. Plants prostrate, commonly creeping and then attached by the rhizoids to the substratum, 50-150 $\times 1.2-1.7(-2.5) \mathrm{mm}$. Rhizoids virtually absent to more or less dense, in brownish divergent fascicles. Stem sparsely to regularly pinnately and (rarely) bipinnately branched, 200$300 \mu \mathrm{m}$ wide. Dorsal leaf lobes imbricate, strongly incurved to dorsal side, arcuately inserted, not decurrent, obliquely oblong to obliquely ovate, $0.8-1.2(-2.0) \times 0.6-1.0(-1.5) \mathrm{mm}$, dorsal margin crispate to entire, with 3-10 cilia each 1 (2-3) cells wide at the base (rarely in depauperate phases teeth may be virtually absent), cilia longer near apex, ventral margin sparsely toothed to entire, apex rounded to obtuse, dentate to shortly ciliate. Ventral leaf lobes contiguous, arcuately inserted, shallowly concave to nearly plane, widely connate with lobe, lingulate to obliquely obovate, 

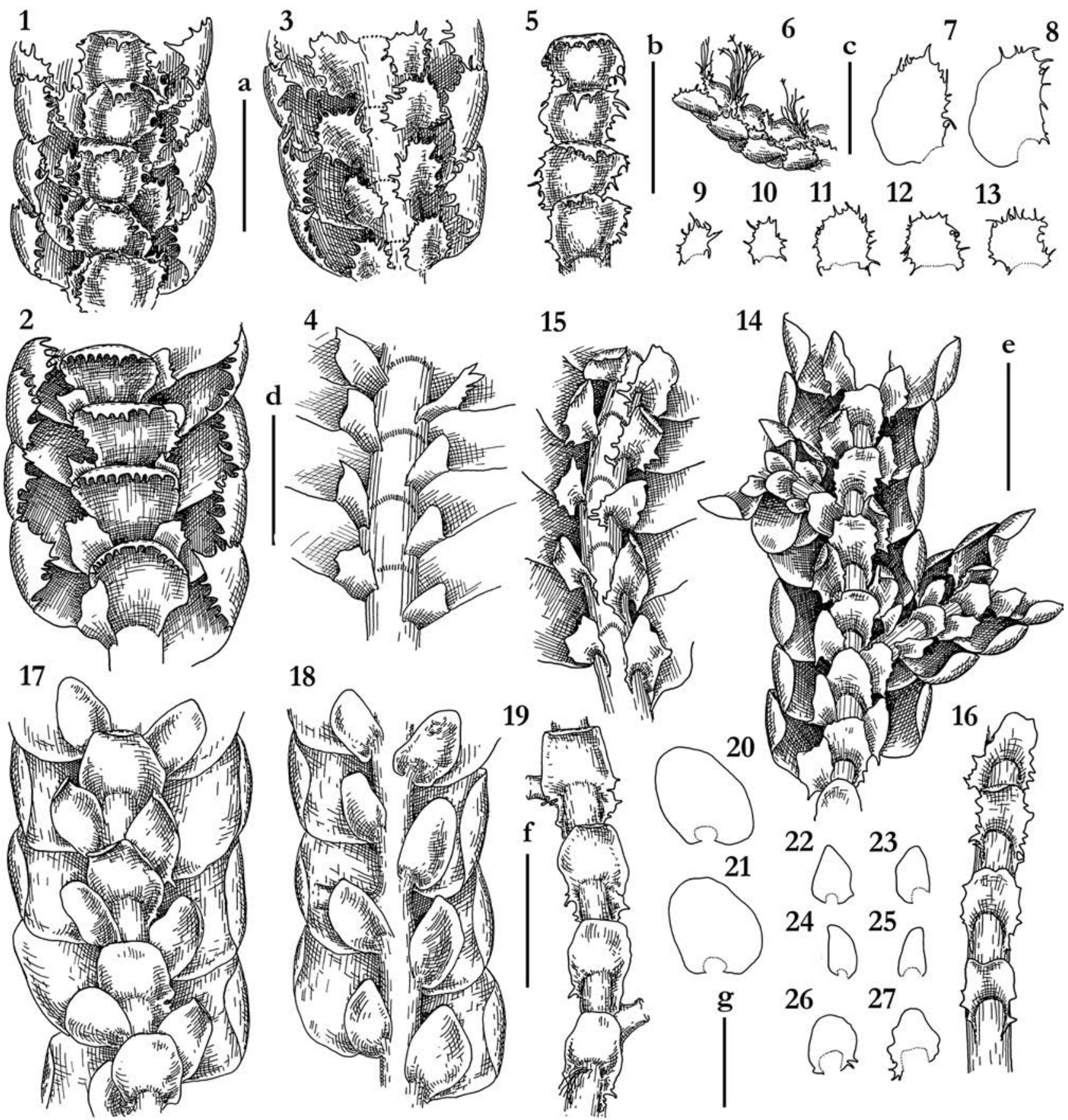

15

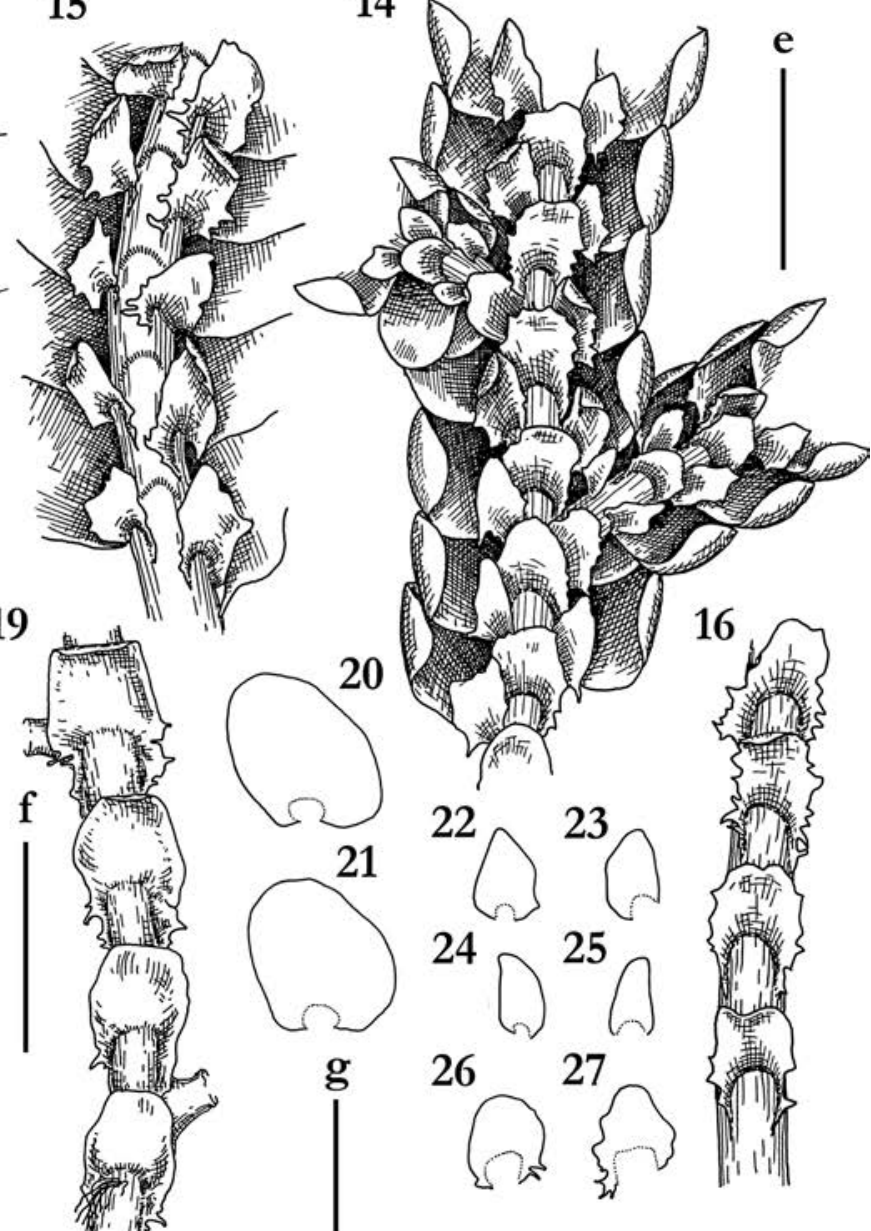

Figure 4 Porella faurieri (Steph.) S. Hatt.: 1, 2 - plant habit, fragment, ventral view; 3, 4- plant habit, fragment, ventral view, underleaves detached; 5 - plant habit, fragment, ventral view, leaves detached; 6 - lateral view, fragment, showing rhizoids fascicles; 7, 8 - dorsal lobes; 9, 10 - ventral lobes; 11-13 - underleaves. Scales: a $-1 \mathrm{~mm}$, for 1, 3, 5; b-1 mm, for 6; c - $1 \mathrm{~mm}$, for 7-13; d - $1 \mathrm{~mm}$ for 2, 4 (1, 3, 5-13 from P-1519-12, 2; 4 from K-45-7-05, VBGI). Porella gracillima Mitt.: 14, 17 - plant habit, fragment, ventral view; 15, 18 - plant habit, fragment, ventral view, underleaves detached; 16, 19 - plant habit, fragment, ventral view, leaves detached; 20, 21 - dorsal lobes; 22-25 - ventral lobes; 26, 27 underleaves. Scales: $\mathrm{e}-1 \mathrm{~mm}$, for 14-16; f - $1 \mathrm{~mm}$, for 17-19; $\mathrm{g}-1 \mathrm{~mm}$, for 20-27 (14-16 from S-32-17a-06; 17-27 from P-34-8-14, VBGI)

$0.4-0.5(-0.7) \times 0.3-0.4(0.5) \mathrm{mm}$, not decurrent, densely to sparsely toothed, with teeth longer toward the apex or in the middle of lateral sides or equal in length, teeth not branched, straight to variously incurved, 1-3 cells wide at the base. Underleaves deflexed from the stem, contiguous to imbricate, sinuately inserted, transversely elliptic to nearly orbicular, $0.4-0.7 \times 0.5-1.0 \mathrm{~mm}$, apex rounded, toothed, teeth equal in length or larger in the middle of lateral side or apically, decurrent to $1 / 4$ of stem width. Cells in dorsal lobe middle $15-25(-32) \times 12-27 \mu \mathrm{m}$, subisodiametric to shortly oblong, thin-walled, trigones moderate, triangular to concave, cuticle smooth; oil-bodies $10-25$ per cell, 2.5-5.0 $(-6.0) \times 2.0-2.8 \mu \mathrm{m}$, shortly fusiform to ellipsoidal, homogenous. Dioicous. Gynoecia on short lateral braches (branch shorter than mature perianth), perianth 2.8-3.0 $\times$ 1.6-20 mm, with 2 dorsal, two lateral and one ventral loose keels, loosely dorsiventrally compressed. Seta 4-5 mm long (2-3 $\mathrm{mm}$ within perianth and $2 \mathrm{~mm}$ out of the perianth). 
Capsule ellipsoidal, ca. 1.5-1.7 mm long, lacerate into 4-5 irregular lobes.

Differentiation. Porella faurieri is most similar to P. vernicosa, with which it has been confused. The two taxa differ slightly in size ( $P$. faurieri is mostly narrower than $2.0 \mathrm{~mm}$ wide, whereas well-developed $P$. vernicosa is wider than $2 \mathrm{~mm}$ ) and, especially, in the distribution of teeth and the shape of the underleaves. Underleaves of P. vernicosa are nearly triangular to trapezoidal with truncate apex, while the underleaves of $P$. faurieri are suborbicular to transversely elliptic. The underleaf apex is commonly entire or sparsely toothed in P. vernicosa, and the teeth are longer along underleaf lateral margins and longest on the relatively long decurrent underleaf base. In contrast, the underleaves of $P$. faurieri are toothed throughout, with the teeth commonly longer apically or around middleaf (but never on the short decurrent underleaf base). The species also differ in their perianths and sporophytes. The perianth of $P$. vernicosa is obtrapezoidal in outline, wider than long, and distinctly dorsiventrally compressed, and the seta does not emerge from the perianth (even the capsule is usually hidden within the perianth), whereas the perianth of P. faurieri is nearly ovate, more weakly dorsiventrally flattened, longer than wide, and the seta emerges for some distance beyond the mouth of the perianth. Another taxon with which $P$. faurieri may be confused due to its densely imbricate strongly incurved leaves and glossy appearance is $P$. gracillima. The latter species, however, differs in having the dorsal lobe apices entire and the underleaves nearly triangular as well as in commonly the smaller cells in the dorsal lobe middle.

Ecology. Neutrophilic to acid-tolerant mesophyte occurring in partly shaded to nearly open areas in the sites under the influence of oceanic air masses. In the Russian Far East mainland it mostly grows on rock, although southward (in Korean Peninsula) and eastward (Sakhalin and Kurils) it is more common on wood. It occurs on partly shaded cliffs along streams (but outside the zone where it receives water droplets from splashing of the stream) in mixed to deciduous (broadleaved zonal and also floodplain forests). In the southern mainland of the Russian Far East this species commonly grows on tree trunks from the base to ca. 1-2 m above ground, preferring Alnus, Tilia and Acer (but never found on conifers), and it rarely occurs on decaying wood. On Sakhalin and the Kuril Islands it also grows over the bark of Salix trees. In the Kurils the species sometimes occurs also on fine soil on steep slopes near the sea coast (covered by coastal meadow) or over sea-facing vertical cliffs. The species is highly sensitive to constantly high humidity and it is seldom found more than $10-20 \mathrm{~km}$ from the sea in the continental part of the Far East (unlike P. vernicosa) except in rather open sites at high elevation. The species commonly forms pure mats (especially when growing on bark), although it sometimes occurs on rock together with Barbilophozia barbata (Schmidel ex Schreb.) Loeske, Diplophyllum taxifolium (Wahlenb.) Dumort., Metrgeria furcata (L.) Dumort., M. lindbergii Schiffn., M. pubescens, Plagiocbila ovalifolia Mitt., and Radula obtusiloba Steph. The taxon shows opposite altitudinal patterns in insular and continental parts of the Russian Far East. In Sakhalin Province the distri- bution of the taxon starts from near sea level and hardly exceeds $300 \mathrm{~m}$ a.s.l. (with the only one exception in Zhdanko Mt. on Sakhalin Island), whereas in Primorsky Territory this species is usually found at higher elevation (mostly from 500 to $1600 \mathrm{~m}$ a.s.l.). Two explanations may be given: 1) a requirement for high humidity (noticeably increasing in middle elevations of Sikhote-Alin Mts.) and 2) replacement of $P$. faurieri by the closely related $P$. vernicosa (absent in the insular part of the Russian Far East). The situation is similar in the Republic of Korea, where most localities of the species lie above 800 a.s.l.

Distribution. The species is primarily of KoreanJapanese distribution, although spreading northward to Attu Island of the Aleutians (where it is probably relictual). Within the Russian Far East Porella faurieri known from high elevations in the Middle and Southern Sikhote-Alin Mts. and also occurs in Sakhalin and the South Kurils, where it is locally abundant (Fig. 2: 3).

Porella gracillima Mitt., Trans. Linn. Soc. London, Bot. 3 (3): 202,1891. Fig. 4:14-27

Porella gracillima subsp. urogea (C. Massal.) S. Hatt. \&

M.X. Zhang, J. Jap. Bot. 60: 323, 1985.

Porella gracillima var. urogea (C. Massal.) S. Hatt., J.

Hattori Bot. Lab. 34: 420, 1971.

Porella urogea (C. Massal.) P.C. Chen, Observationes ad Florulam Hwangshanicum 10, 1965.

Madotheca urogea C. Massal., Mem. Accad. Agric. Verona, 73(3): 28. 1897.

Madotheca ussuriensis Steph., Sp. Hepat. 4: 299, 1910.

Description. Plants glossy (especially when dry), brownish green to yellowish green, relatively rigid, 50-200 × 1.1$2.0(-2.2) \mathrm{mm}$, forming loose patches. Rhizoids virtually absent. or sometimes present on branches as dense, divergent and short $(<1.0 \mathrm{~mm}$ long) brownish fascicles originating near underleaf bases and closely attaching plants to the substratum. Stem 200-300 $\mu \mathrm{m}$ wide, freely pinnately, more rarely bipinnately branched, greenish brown. Dorsal leaf lobes imbricate or nearly so, rarely distant in lax phases from shady places, strongly turned to ventral side, obliquely ovate, 750-2200 × 600-950 $\mu \mathrm{m}$, dorsally arcuately inserted, sometimes shortly decurrent, margin entire to loosely crispate near dorsal base, rarely crispate around the whole margin. Ventral leaf lobes distant, canaliculate to loosely turbinate near the end, subparallel to the stem axis, obliquely spreading, triangular, $250-600(-800) \times 180-300 \mathrm{~cm}$, decurrent for $0.5-1.0$ of stem width, decurrencies sometimes continued as the row of paraphyllia-like structures (in the most cases it is very difficult to distinguish these paraphyllialike structures from the end of densely toothed decurrent ventral lobe margin), with acute (but not prominent) apex, apical part sometimes turned (when flattened in the slide) toward the stem axis, nearly entire except for prominent teeth near ventral base and especially in the decurrencies, rarely loosely crispate-sparsely dentate above base, but never near the lobe end. Underleaves distant, decurrent for ca. 1.0-1.5 of stem width, nearly ovate-triangular, with truncate apex, apex reflexed or erect and turned away from the stem, 200-550(-700) × 250-500 $\mu \mathrm{m}$, nearly entire, but dentate-ciliate (rarely with branched cilia) in decurrent area 
and sometimes crispate to sparsely dentate above. Cells in dorsal lobe middle $10-20(-25) \times 8-20(-25) \mu \mathrm{m}$, nearly thin-walled, with moderate, concave to distinctly convex trigones, cuticle smooth; oil bodies 10-25 per cell, shortly ellipsoidal to shortly fusiform, homogenous, bluish greenish to colorless, smooth-surfaced, 2.0-7.0 × 1.5$3.0 \mu \mathrm{m}$. Dioicous. Androecia not seen and the description is not found in the literature (unknown?). Gynoecia on short lateral branches arising from the main stem, bract ventral lobe ovate-narrowly triangular, dentate, bract dorsal lobe ovate, not or sparsely dentate, with apex rounded, leaf lobes of the main axis near origin of gynoecial branch may be scarcely dentate near apex.

Variation. Porella urogea (C. Massal.) S. Hatt. is recognized as a 'knowledge problem' taxon in Söderström et al. (2016). It is no more than a variety of P. gracillima (as it was treated by Hattori 1978). Hattori (1971) distinguished his 'var. urogea' from var. gracillima primarily by the rows of of paraphyllia-like structures that continue below decurrent dentate ends of the underleaf and ventral lobe bases. This character seems to be variable, with 'paraphyllia-like' structures generally present in larger plants (which produce more teeth in decurrent bases of ventral lobes and underleaves) and sometimes present only on some ventral lobes or in some plants within the patch. Hentschel et al. (2007) accepted subspecies status for P. urogea, but did not provide any arguments in favor of this decision. In this study, their analysis includes four specimens that are genetically very similar, including $P$. spinulosa (Steph.) S. Hatt. (an obvious misidentification), two specimens named as $P$. gracillima s. str. from East Asia and one specimen named as 'ssp. urogea' from North America. Hentschel et al. (2007) correctly noted that the phylogenetic tree in their paper confirmed the occurrence of P. gracillima s.l. in North America. There are no reasons to assume that their North American 'ssp. urogea' specimen is the same as the East Asian 'P. urogea', if even they are different from East Asian P. gracillima s. str., or to treat American plants as a separate subspecies based on information available from Hentschel et al. (2007). The two varieties, which are better treated as modifications in our estimation, may be different by the following key:

- Decurrent portion in the base of the ventral leaf lobes and underleaves crispate to entire or sparsely toothed.....

P. gracillima var. gracillima

- Decurrent portion in the base of ventral leaf lobes and underleaves densely toothed, sometimes continues as the line of paraphyllia-like teeth below the end of the decurrent portion of the ventral lobes and underleaves.....

P. gracilima var. urogea

Differentiation. The species is characterized by its entire to slightly crispate dorsal leaf lobes, and apical halves of ventral lobes and underleaves, its glossy appearance, and the small size of the cells in dorsal lobe middle. Porella gracillima may be confused with other 'glossy' Porella species; in the Russian Far East, these are P. vernicosa, P. spinulosa and $P$. faurieri. However the latter two are distinctly different in having shortly decurrent ventral lobe bases and ventral lobes and underleaves more or less evenly and equally toothed along the margin. The presence of teeth on the leaf apex is not constant in P. vernicosa and the apex may some- times be entire, especially in P. spinulosa. P. gracillima also commonly has distinctly smaller cells (in most cases less than $20 \times 20 \mu \mathrm{m}$, versus over $20 \times 20 \mu \mathrm{m}$ ).

Ecology. In the area treated this is a neutro- to basiphilic (probably Ca-tolerant) xero-mesophyte. It regularly occurs in limestone areas of the southern part of the Russian Far East, where it grows in partly shaded to open, mesic to almost dry limestone cliffs, avoiding, however, full sun. This occurrence in the Russian Far East is probably the result of the species competition in this habitat, with more temperate adapted taxa, like $P$. vernicosa (which rarely grows with $P$. gracillima). In this competition $P$. gracillima is excluded from more mesic habitats and limited to more dry ones (limestone cliffs), where it is sometimes even associated with $P$. caespitans. In northern localities (Amur Province) it occurs together with $P$. platyphylla over limestone rocks. Aside from limestone and neutral dry cliffs this species occurs on dry trunks of Tilia and Quercus and some other broadleaved trees (never on conifer or Betula trunks). Porella gracillima commonly forms pure mats, where it rarely occurs with the aforementioned Porella spp. and also with Frullania davurica Hampe, F. taradakensis Steph., Lejeunea japonica Mitt., Metzgeria pubescens, and Plagiochila ovalifolia Mitt. In northern China (Inner Mongolia) it was found on dry cliffs with Reboulia hemisphaerica (L.) Raddi. Altitudinal range of this species starts in continental areas from near sea level and stretches to $300 \mathrm{~m}$ a.s.l., and approaching 500 a.s.l. in large limestone massifs in Dalnegorsk Town Area and Lozovyi (Chandolaz) Range. In Sakhalin Island there are two localities higher than $900 \mathrm{~m}$ a.s.l., on Vaida Mt. and one (of unknown altitude, but probably low) in "Wladimiroff" (leg. U. Faurie), that probably means the current microdistrict of Yuzhno-Sakhalinsk City. The species is probably replaced in low elevations there by $P$. faurieri. Westward in South Siberia (only one specimen seen) it was collected in $460 \mathrm{~m}$ a.s.l., whereas in Chinese Inner Mongolia it grows at 1500 and even $1760 \mathrm{~m}$ a.s.l. (probably due to higher moisture in higher elevations).

Distribution. This is a temperate East Asian species, extending south to Chinese Sichuan and Yunnan, westward to the Altai Mts., but commonest in Korea and Japan and the southern part of the Russian Far East (being in the latter mostly confined to the limestone and other basic rocks). Within the Russian Far East it is locally abundant in southern Primorsky Territory (south of $45^{\circ} \mathrm{N}$ ), northward as a rarity in the Anyui River Valley $\left(49^{\circ} \mathrm{N}\right)$ and Tukuringra Range (almost $54^{\circ} \mathrm{N}$ ). Known on Sakhalin Island from old collections in Yuzhno-Sakhalinsk City (probably extinct there now) and an isolated recent locality on Vaida Mt. (Fig. 2: 4).

Porella grandiloba Lindb., Acta Soc. Sci. Fenn. 10: 234, 1872 [1873]. Fig. 5:1-14

Description. Plants dull to somewhat glossy, yellowish to brownish or deep green, rarely deep brown-green southward of the area treated (on the Korean Peninsula), becoming brown in older herbarium specimens, relatively rigid to rather soft in moist and shady habitats, 50-150 $\times(2.2-)$ 2.8-3.6(-4.0) mm. Rhizoids virtually absent, rarely present (commonly in plants from wet stones), brownish, shorter 

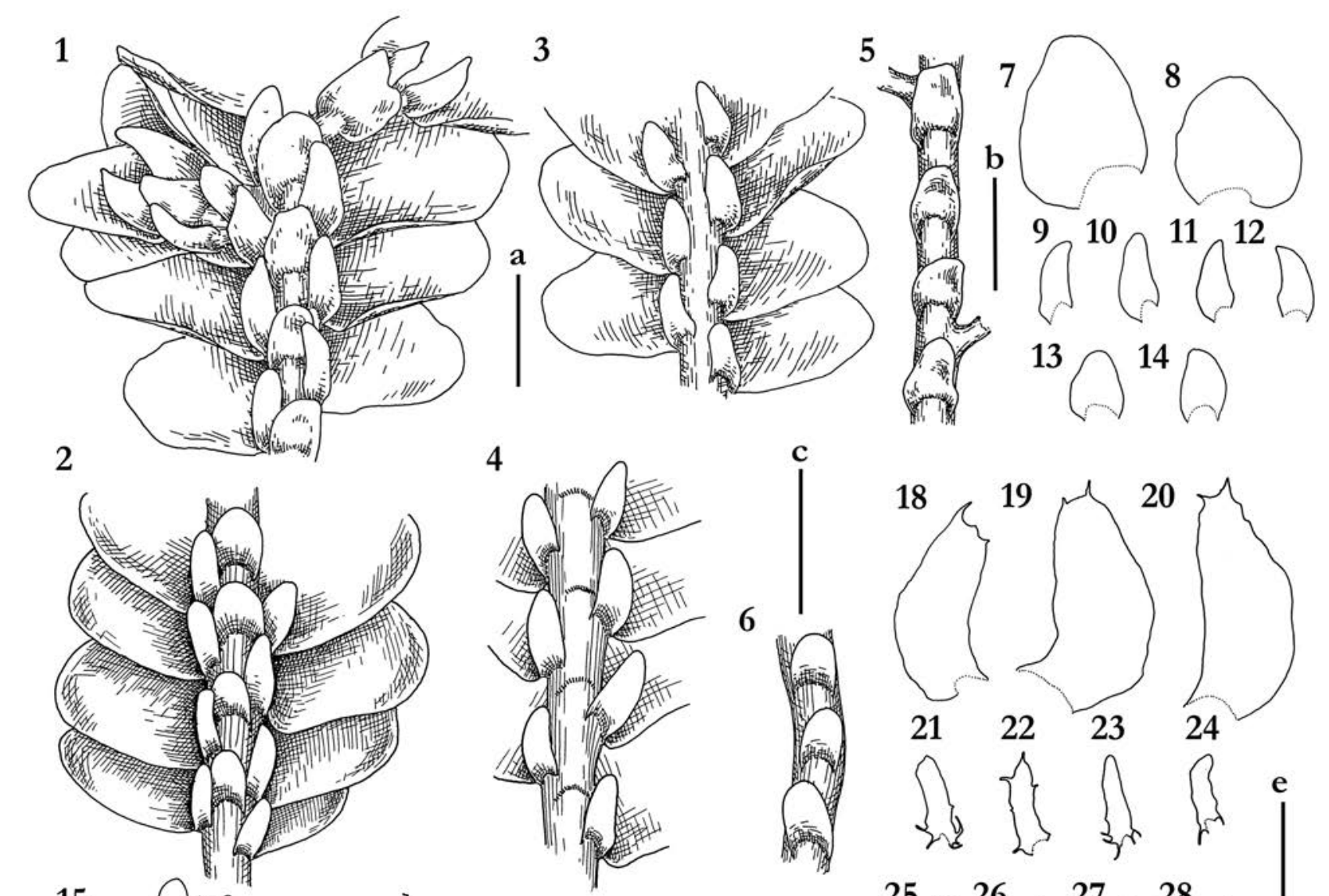

19
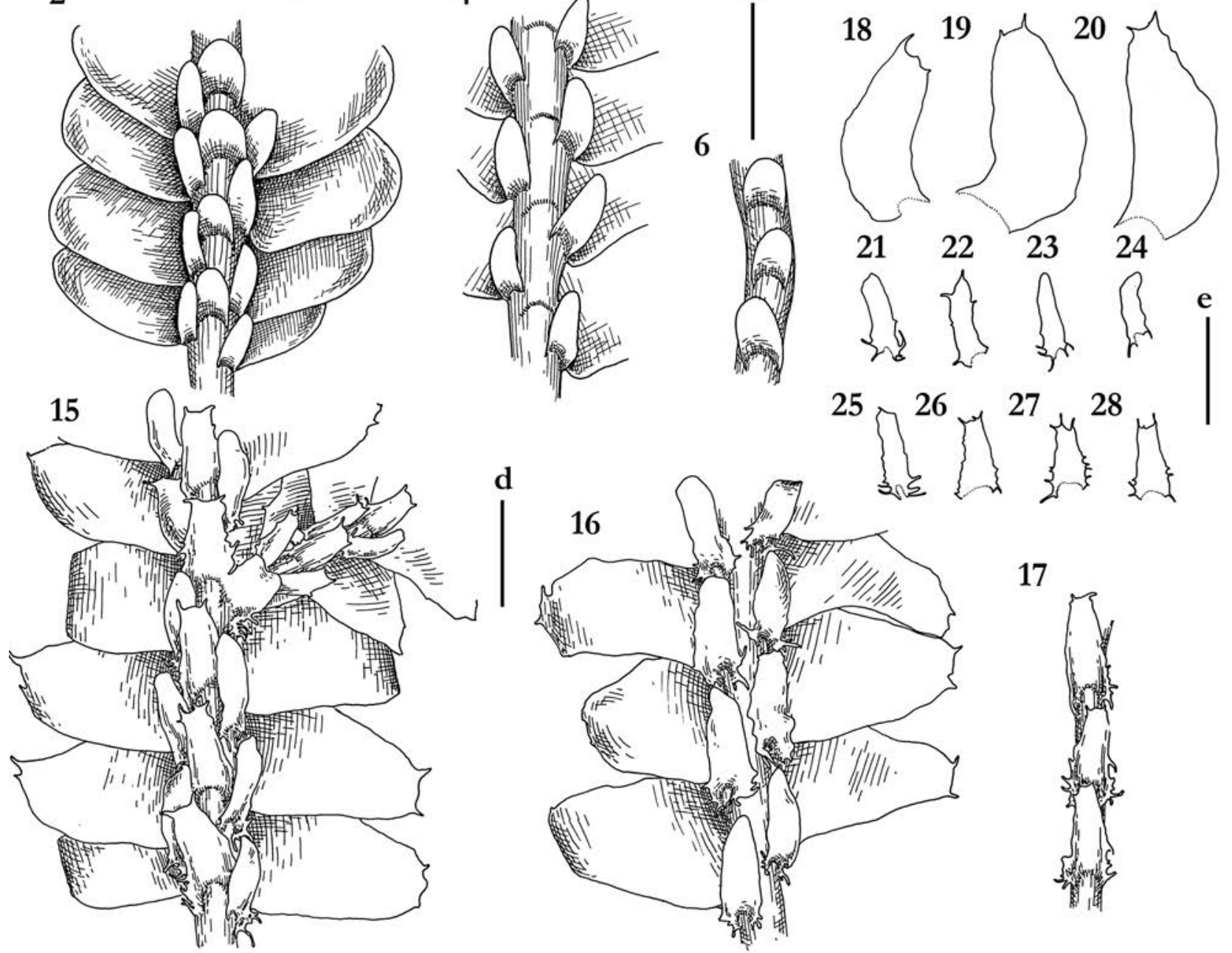

Figure 5 Porella grandiloba Lindb.: 1, 2 - plant habit, fragment, ventral view; 3, 4-plant habit, fragment, ventral view, underleaves detached; 5 , 6 - plant habit, fragment, ventral view, leaves detached; 7, 8 - dorsal lobes; 9-12 - ventral lobes; 13,14 - underleaves. Scales: a - $1 \mathrm{~mm}$, for 1, 3, 5; b - $1 \mathrm{~mm}$, for 7-14; c - $1 \mathrm{~mm}$, for 2, 4, 6 (1, 3, 5, 7-14 from P-81-21-07; 2, 4, 6 from P-4-6-08, VBGI). Porella oblongifolia S. Hatt.: 15 - plant habit, fragment, ventral view; 16 - plant habit, fragment, ventral view, underleaves detached; 17 - plant habit, fragment, ventral view, leaves detached; 18-20 - dorsal lobes; 21-24 - ventral lobes; 25-28 - underleaves. Scales: $\mathrm{d}-1 \mathrm{~mm}$, for 15-17; f - $1 \mathrm{~mm}$, for 17-19; e - 1 $\mathrm{mm}$, for 18-28 (all from P-34-29-14, VBGI)

than $0.8 \mathrm{~mm}$ long, originating near underleaf bases. Stem $350-400 \mu \mathrm{m}$ in diameter, freely, mostly irregularly pinnately, but rarely bipinnately branched (gynoecia and androecial branches sometimes form branches of the second order and then fertile plants are bipinnately branched), yellowish brown. Dorsal leaf lobes contiguous to (more commonly) imbricate, nearly plane to slightly convex or ob-canaliculate, sometimes with a slightly incurved ventral margin, entire to loosely crispate along the whole margin or only on one side (postical or antical), obliquely ovate to oblong-lingulate, rarely nearly rounded, $1.5-1.8 \times 1.1-1.8 \mathrm{~mm}$, dorsally arcuately inserted, not or, rarely, barely decurrent, not or obscurely 
connate with ventral lobes, with a rounded or, rarely, obtuse apex. Ventral leaf lobes appressed to the stem, contiguous to imbricate (then overlapping to $1 / 3$ of next most distal ventral lobes' length), narrowly ovate to oblong-lingulate, sometimes slightly falcate, $0.6-1.0 \times 0.3-0.6 \mathrm{~mm}$, arcuately inserted, not or barely decurrent, margin entire, sometimes loosely crispate, especially near dorsal base, rarely with one protrudent tooth near its dorsal base, apex rounded. Underleaves appressed to the stem, nearly triangular, apex truncate or shortly emarginate, margin entire to crispate near base on both sides, barely to slightly (to $1 / 3$ of stem width) decurrent, $0.6-0.7 \times$ $0.5-0.7 \mathrm{~mm}$. Cells in dorsal lobe middle nearly isodiametric, (20-)25-37 $\mu \mathrm{m}$ in diameter, cell walls thin, trigones moderate in size to small, concave, cuticle smooth; oil bodies 25-50 per cell, smooth, ellipsoidal, 1.0-5.0 × 2.0-3.0 $\mu \mathrm{m}$. Dioicous. Androecia terminal on short lateral branches, spicate, with 1-2 pairs of sterile leaves in the base and then with 6-814 and sometimes more pairs of bracts, monoandrous. Gynoecia freely produced (but in most cases remaining unfertilized), on up to 6-7 short lateral branches for $1 \mathrm{~cm}$ of the stem length; bract lobes entire, connate with bract ventral lobes; bract ventral lobe narrowly triangular, with acute (or nearly so) apex; perianth dorsiventrally compressed, nearly orbicular in the projection, with truncate upper part, mouth crenulate along margin, later slightly lacerate due to capsule emerging, 1.8-2.4 × 1.8-2.2 mm. Capsule (in the Russian Far East known with capsules from Sakhalin Island only) slightly exerted from the perianth (seta not visible without opening perianth). Spores chlorophyllose, 25-37 $\mu \mathrm{m}$ in diameter, with many needle-shaped projections (papillae). Elaters bispiral, 7-8 $\mu \mathrm{m}$ wide.

Variation. Plants from wet and shady habitats commonly bear rounded lobes and relatively short (to $0.3 \mathrm{~mm}$ long) triangular ventral lobes, and are sometimes freely rhizogenous. Those modifications resemble Porella cordaeana, a species not recorded in the Far East, from which $P$. grandiloba differs in its very short-decurrent ventral lobe (vs. a long-decurrent ventral lobe in P. cordaeana). Stony substrates and humus slopes are not favorable for the species and then small-sized plants (from $2.0 \mathrm{~mm}$ wide and $2 \mathrm{~cm}$ long) may be only found in these habitats.

Differentiation. Porella grandiloba is an easily identified species, characterized by a dull to somewhat glossy appearance, rounded leaf dorsal lobe apices, and not or very barely decurrent ventral leaf lobes. In the herbarium it has occasionally been confused with $P$. chinensis, a species of much more limited distribution in the Far East, from which it differs in its not or barely decurrent ventral leaf lobes (versus ventral lobes decurrent for 1.0-1.5 of stem width in $P$. chinensis). Another species it could be mistaken for is P. platyphylla, which also has rounded leaf apices. However, the latter species commonly has wider, larger and evidently decurrent ventral leaf lobes (decurrent to 1.0-1.5 of stem widths) as well as a positive IKI reaction. The distinctions from $P$. oblongifolia, a rare taxon of the southernmost flank of the area, are in rounded and entire dorsal leaf lobe apex (versus apex truncate and commonly sparsely toothed) and in entire to crispate ventral leaf lobe base (versus densely and prominently toothed in P. oblongifolia).
Ecology. Acidophilic to neutrotolerant mesophyte in the Russian Far East. Predominantly an epiphytic taxon growing on trunk bases of broadleaved trees, more rarely growing over rocky substrata, decaying wood and fine soil and humus on steep slopes, where it sometimes produces depauperate (or otherwise deviant) forms. Southward of our area (in Korea and Japan) the taxon becomes rarer and its ecology somewhat changes. For instance, on the Korean Peninsula the species has been found on dry limestone (Kor13-09-11) and on wet cliffs near a stream. In the continental part of the Russian Far East this species is nearly restricted to cool-temperate broadleaved forest (although sometimes with noticeable admixture of conifers like Pinus koraiensis Siebold et Zucc., Abies holophylla Maxim., A. nephrolepis (Trautv. ex Maxim.) Maxim., and Taxus cuspidata Siebold \& Zucc.), rarely spreading to sea coastal cliffs adjacent to these communities. Often it is the only taxon occurring in pure stands of Quercus mongolica Fisch. ex Ledeb. Similar community preferences may be observed on the Korean Peninsula. However, in Sakhalin and the South Kurils this species may grow on trunks of Salix trees and also over steep slopes (including eroded tufa) overlooking the sea in the areas occupied by windy tubndra like communities (but not true tundra). The species usually forms pure patches, more rarely it is associated with Lejeunea japonica, Metzgeria pubescens, Porella faurieri (Sakhalin) and P. vernicosa (Primorsky Territory), and rarely the species is overgrown by epibryophytic Cololejeunea ornata A. Evans. This species grows from near to sea level to above 1000 a.s.l. both in insular and mainland parts. In the southern part of the Russian Far East it is one of the most common taxa of the genus (sharing this role with $P$. vernicosa in continental areas and P. faurieri in insular areas). Southward, on the Korean Peninsula, this taxon occupies elevations between 250 and $1400 \mathrm{~m}$ a.s.l. and may be expected higher).

Distribution. This is a taxon of cool temperate Russian Far East-Korea-Japanese distribution, penetrating southward to Taiwan. Originally the species was described from Sakhalin, and it is one of the most common taxa of the genus in the south of the Russian Far East. Most of the localities lie southward of $45^{\circ} \mathrm{N}$, although the species penetrates northward to Bol'shekhekhtsirsky State Nature Reserve, Khabarovsk City surroundings $\left(48^{\circ} \mathrm{N}\right)$, and the Anyui River valley $\left(49^{\circ} \mathrm{N}\right)$ on Sakhalin Island $\left(51^{\circ} \mathrm{N}\right)$, and the type locality of the species from Due Bay, Sakhalin, where it has not been recollected in recent years despite special searches) (Fig. 2: 5).

Porella oblongifolia S. Hatt., J. Jap. Bot. 19 (7): 200, 1943. Figs 5:15-28, 6:1-3

Description. Plants dull to somewhat glossy (when dry), 30-150 × 2.3-4.8 $\mathrm{mm}$ (depauperate plants as little as $1.8 \mathrm{~mm}$ wide), forming pure loose patches or commonly mixed with mosses (mostly Anomodon). Rhizoids not rare, in spreading, brownish to rusty brownish short fascicles 0.5-0.7 mm long. Stem brownish to yellowish brown, 300 $400 \mu \mathrm{m}$ in diameter, freely and regularly (seldom irregularly) pinnately branched. Dorsal leaf lobes contiguous to slightly imbricate (overlapping ca $1 / 4$ of the next most distal dor- 
sal lobe), nearly plane to slightly convex, 1.1-2.2 $\times 0.9$ $1.3 \mathrm{~mm}$, dorsally arcuately inserted, margin entire to loosely crispate, with obtuse teeth near the dorsal leaf base and 1-several short teeth in the lobe apex (absent in weak plants), obliquely ovate-lingulate, rarely somewhat falcate. Ventral leaf lobes oblong lingulate, rarely oblong-ovate, rarely somewhat falcate, appressed to the stem, 0.6-0.7 $\times$ $0.5-0.7 \mathrm{~mm}$, arcuately inserted, decurrent up to $0.3(-0.5)$ of stem width, margin entire or with (1-)2(-4) teeth in apical part and with 1-several prominent and sometimes incurved teeth near base (larger on ventral side), in the decurrent area sometimes densely ciliate-dentate and making the stem appear paraphyllose, $0.7-0.9 \times 0.2$ stem width. Cells in dorsal lobe middle subisodiametric, 22-32 $\mu \mathrm{m}$ in diameter, thin-walled, trigones moderate in size to small, convex to concave, cuticle smooth. Dioicous. Androecia not seen and the descriptions were not found in the literature. Gynoecia on lateral branches, with 2-5 pairs of sterile leaves below bracts; bracts and bracteole dentate to dentate-ciliate throughout, bract dorsal lobe acute.

Variation. The Russian Far East forms the northern edge of the species range. Porella oblongifolia is represented here mostly by depauperate forms that are characterized by leaves with edentate apices. Well-developed plants of the species were found on the eastern slope of the Partizansky Range only - an area with the mildest and wettest climate in Primorsky Territory. Depauperate forms tend to be smaller than well-developed specimens, and they often have edentate leaves. There is a great variation in the size of the trigones in the cells of dorsal leaf lobes, with large trigones present in habitats with high light level.

Differentiation. The species superficially resembles Porella gracillima with which it shares oblong-lingulate ventral leaf lobes and ovate-lingulate dorsal lobes, also edentate in depauperate phases of $P$. oblongifolia. The main differentiating feature of the latter is the presence of sharp teeth and sometimes cilia near the ventral lobe bases, and cell size in the dorsal leaf lobe. In well developed phases (rare in the Russian Far East) the two species may be different in lobe apices that bear 1-several teeth in P. oblongifolia (versus completely entire). It should be noted that dentate lobe apices are usually found on a few leaves in even depauperate shoots of the species. In well developed phases the underleaves (rarely also ventral leaf lobes) have teeth distributed near their apices, while underleaf apices are entire in P. gracillima. Another similar species is $P$. tosana (Steph.) S. Hatt. (= P. acutifolia ssp. tosana (Steph.) S. Hatt.), which differs from P. oblongifolia in triangular lobe apices bearing many (5-15) teeth descending to almost middle part of the both sides of the dorsal lobe. However, $P$. tosana (a warm temperate to subtropical East Asian taxon) is not known from the Russian Far East.

Ecology. This species is a neutrophilic (to acido-tolerant) mesophyte, occurring in the Russian Far East over rocky substrata in taxonomically rich broadleaves-coniferous forests with several East Asian floristic elements in tree layer (Taxus cuspidata, Pinus koraiensis, Kalopanax septemlobus (Thunb.) Koidz., Phellodendron amurense Rupr., Juglans manshurica Maxim., etc.), many of these shrubs and lianas; the community may be called Manchurian taiga. It is com- monly associated with Anomodon, but almost without admixture of other hepatics. The only hepatic species we observed growing with P. oblongifolia was Cephaloziella spinicaulis Douin. Southward in Japan the species frequently grows on tree bark - a rare habitat for it in the Russian Far East and Korea, where it is predominantly epilithic. It prefers slightly shaded habitats and never occurs in full sun, although depauperate forms were collected twice in shady habitats. This species is found away from the immediate seacoast from about 200 to $850 \mathrm{~m}$ a.s.l. Incomplete data from Japan and Korea suggests the same pattern there.

Distribution. The species is sporadically occurred in eastern spurs of the Himalaya (southward to Yunnan), North-East China, Japan, the Korean Peninsula and the continental part of the Russian Far East. This is a rare species in the Russian Far East, all known localities are situated southward of $44^{\circ} \mathrm{N}$ and within southern part of Sikhote-Alin Mts. The supposed record of Porella nitens (Steph.) S. Hatt. for "ad flumen Maiho super" in Piippo (1990) with reference to Hattori (1967) is not correct. Firstly, Piippo (1990) referred this record to Chinese Heilongjiang, although it is located in the southern part of Primorsky Territory (current name Artyomovka River). Secondly, Hattori (1967) recorded Porella oblongifolia for that locality, not P. nitens which precedes it in the paper. Porella nitens was recorded by Hattori (l.c.) for Yunnan on page 142 of the cited paper, whereas P. oblongifolia was recorded for East Manchuria on page 143 of the same paper (Hattori 1967) (Fig. 2: 8).

Porella obtusata var. macroloba (Steph.) S. Hatt. et M.X. Zhang, J. Jap. Bot. 60 (11): 325, 1985. Fig. 6:4-21

Madotheca macroloba Steph., Sp. Hepat. 4: 292, 1910.

Porella macroloba (Steph.) S. Hatt. \& Inoue, J. Jap. Bot 34: 209. 1959

Porella thuja f. macroloba (Steph.) S. Hatt., J. Hattori Bot. Lab. 33: 84. 1970.

Porella obtusata f. macroloba (Steph.) S. Hatt., J. Hattori Bot. Lab. 44: 106, 1978.

Description. Plants prostrate or with loosely ascending apices, yellowish green to brownish-green, 50-200 $\times$ 2.0-2.5 mm. Stem yellowish green to deep yellow-green, regularly pinnately to bipinnately branched, 250-300 $\mu \mathrm{m}$ wide. Rhizoids frequently present (may disappear in upper and lower parts of the shoots), united into dense erect spreading fascicles, originating at underleaf bases, rarely at ventral leaf lobes bases, subdivided at the apices, reddish brown to brown, 0.4-1.0 $\mathrm{mm}$ long. Dorsal leaf lobes imbricate (then covering $1 / 3-1 / 5$ of the next most distal dorsal lobe) to (more rarely) contiguous, 1.25-1.7 $\times 1.0$ $1.6 \mathrm{~mm}$, dorsal side arcuately inserted and barely decurrent, margin plane to undulate, entire to loosely crispate, with a loosely tapered apical portion, apex obtuse, sometimes shortly reflexed, obliquely ovate. Ventral leaf lobes slightly concave-canaliculate (if viewed from ventral side), mostly with a shortly reflexed apex, oblong to oblong triangular, oblong ovate and ovate-triangular, 0.5-0.55 $\times$ $0.28-0.4 \mathrm{~mm}$, decurrent for $0.2-0.5$ of stem width, entire, decurrencies rarely toothed, with an acuminate to obtuse apex. Underleaves undulate at margin, with a shortly reflexed apex, decurrent for $0.5-1.0$ of stem width on both 

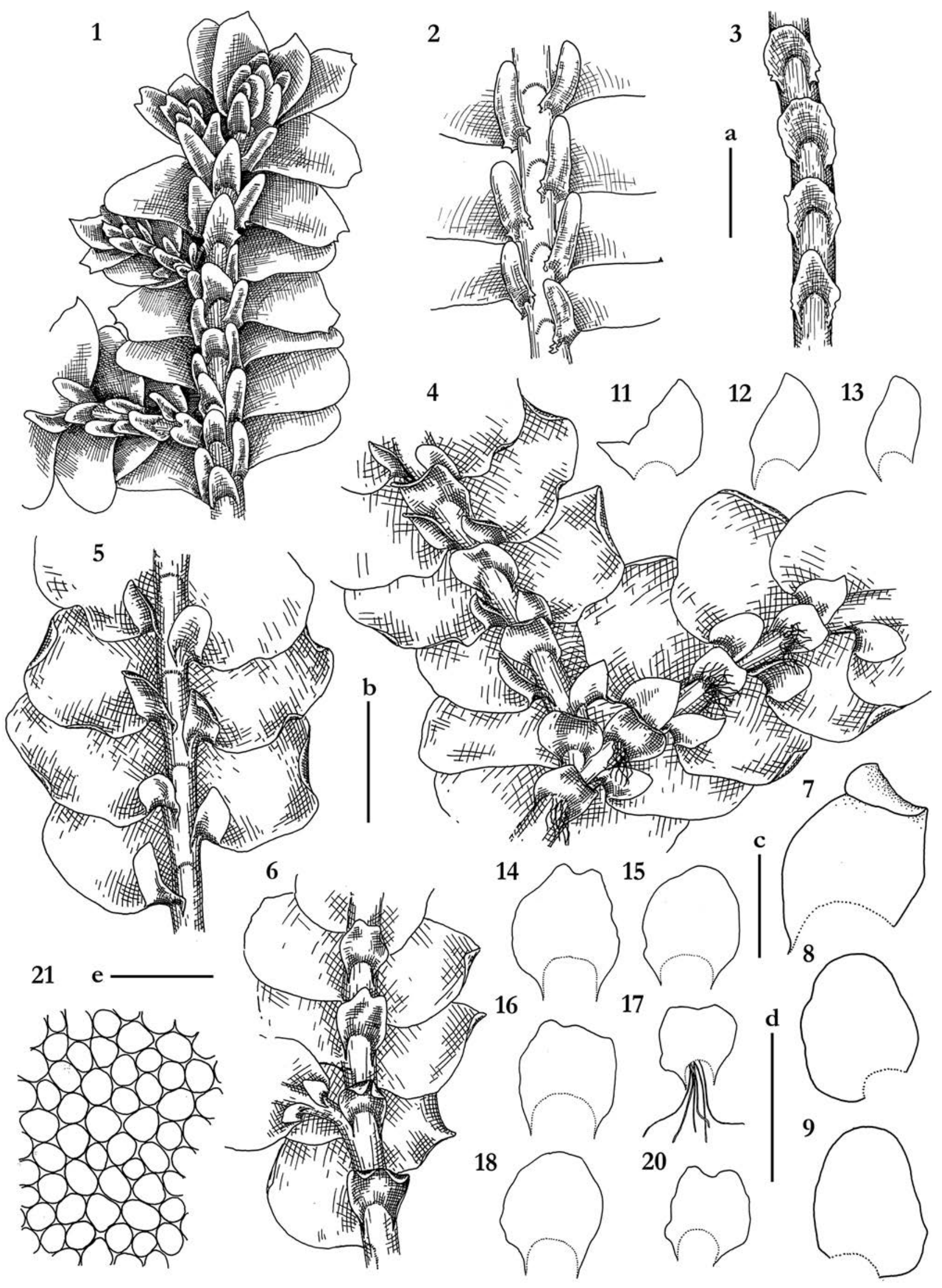

Figure 6 Porella oblongifolia S. Hatt.: 1 - plant habit, fragment, ventral view; 2 - plant habit, fragment, ventral view, underleaves detached; 3 plant habit, fragment, ventral view, leaves detached. Scales: a $-1 \mathrm{~mm}$, for 1-3 (all from P-62-3-08, VBGI). Porella obtusata var. macroloba (Steph.) S. Hatt. \& M.X. Zhang: 4 - plant habit, fragment, ventral view; 5 - plant habit, fragment, ventral view, underleaves detached; 6 - plant habit, fragment, ventral view, ventral lobes detached; 7-9 - dorsal lobes; $11-13$ - ventral lobes; $14-20$ - underleaves; 21 - midleaf cells. Scales: b - 1 $\mathrm{mm}$, for 4-6; c - $1 \mathrm{~mm}$, for 7-9; d - $1 \mathrm{~mm}$, for 11-20; e - $100 \mu \mathrm{m}$, for 21 (all from Am-63-5-18, VBGI) 
sides, decurrencies entire, apex rounded to shallowly emarginate and bilobed, if bilobed then lobes obtuse, 0.5-0.6 $\times 0.6-0.65 \mathrm{~mm}$. Cells in dorsal lobe middle 20.0-35.0 $\times$ 20.0-27.5 $\mu \mathrm{m}$, isodiametric, with somewhat thickened walls, walls brownish yellow in color, with small triangle trigones; cuticle smooth; oil bodies more than 20 per cell, homogenous, spherical to fusiform, 2.5-5.0 × 1.25-2.5 $\mu \mathrm{m}$ (Fig. 6). Androecia and gynoecia not seen, described by Hattori (1970) under Porella thuja f. ovalis (Steph.) S. Hatt.

Variation. There are two recognized varieties in the species, with var. obtusata restricted to Europe whereas var. macroloba occurs in Asia. The morphological differences between these varieties are minor and mostly confined to more round dorsal lobes in the Europe versus more oblong-ovate in Asia (Hattori 1970). These differences, by themselves, are not enough to maintain varietal status of the taxa (Hattori 1970 , treats them as forms), but we suggest the distinct difference in distribution (the gap between Crete and the Indian Himalaya by straight line is over $5000 \mathrm{~km}$ ) may result in higher than varietal differences in the genome and two taxa may actually represent different species (divergent starting from the Tertiary).

Differentiation. The species is characterized by 1) plane to undulate, entire to loosely crispate dorsal leaf lobe margin, 2) shortly, but distinctly decurrent ventral leaf lobe, 3) entire (except the basal part) ventral leaf lobes and underleaves, 4) dorsal leaf lobes distinctly convex, 5) brownish coloration. These features make confusion with other taxa unlikely. Porella grandiloba somewhat resembles this species, but differs in not or barely decurrent ventral leaf lobes and underleaves, oblong (not ovate nor rotund) dorsal leaf lobes and ventral leaf lobes elongate with sides somewhat subparallel (versus widely ovate) and entire near base (versus commonly angular to sparsely toothed there). Porella gracillima differs from P. grandiloba in having much smaller leaf cells (commonly less than $20 \times 20$ versus $20-35 \times 20-27 \mu \mathrm{m}$ ), leaves commonly strongly turned to the ventral side, and ventral leaf lobes commonly decurrent for more than 0.5 of stem width (commonly also densely toothed in the decurrencies).

Ecology. Neutrophilic meso-xerophyte. The habitat of the species in the Russian Far East is quite illustrative: the species occupies dry, open, southwest-facing rocks on the first terrace of the Amur River, growing close to $A c$ rolejeunea, Plagiochasma, Reboulia, Targionia, and other xerophytes and meso-xerophytes. All of these genera are on the northernmost edges of their ranges in Asia and have distributions centered south of the Amur River valley.

Distribution. Eastern Paleo-Tethian (var. macroloba). As was already noted by Hattori (1970), the distribution of the species is quite unusual, with two highly disjunct areas. The first part includes Europe (var. obtusata), from where it is recorded (Shumacker \& Vana 2005) in Albania, Portugal (Azores, Madeira and the mainland), Spain (Balearic and Canary Islands and the mainland), Britain, France (Corsica and the mainland), Greece (Crete), Italy (including Sardinia and Sicily), former Jugoslavia, and Norway. Most of the records belong to localities with Mediterranean climates. Even in the northern fringe of the area, in southwestern Norway (Hassel et al. 2015), the species occupies rocks at sea level in full sun.
On the other hand, the distribution in Asia (var. macroloba) covers (Hattori, 1970) 'lower Himalayas' in India, mountainous Chinese Yunnan, Hubei and Taiwan, North Vietnam and two areas in Japan (southwest Shikoku and the 'Japansea-side' of Honshu). Therefore, the localities in the Asian part of the area have a monsoon climate with a distinct dry period or (in Japan) belong to the driest areas in the country. The distribution of this species is disjunct paleo-Tethian, with the eastern part belonging to its eastern fringe. In this case, the occurrence of the taxon in Amur Province of Russia looks logical (where, however, the distribution should have a relict character due to its northern position). The locality is situated at lower elevation (146 m a.s.l., that is almost Amur floodplain) at $50^{\circ} 41^{\prime} \mathrm{N}$ - the northernmost locality in Asia, 10 degrees latitude north of the northernmost known location in Japan, although in Europe the species (var. obtusata) occurs farther north in Norway (Hassel et al. 2015) (Fig. 2: 8).

Porella platyphylla (L.) Pfeiff., Fl. Niederhessen 2: 234, 1855. Fig. 7:1-16

Jungermannia platyphylla L., Sp. Pl. 1: 1134, 1753.

Madotheca platyphylla (L.) Dumort., Syll. Jungerm.

Europ.: 31, 1831.

Description. Plants dull, yellowish green to brownish green or deep green, rarely golden green, relatively rigid, 50$200 \times 1.8-2.6 \mathrm{~mm}$, longer branches sometimes becoming depauperate (small-leaved) and with stem strongly rhizogenous. Rhizoids virtually absent on the main stem, but common at the ends of branches of the first order, brownish, obliquely upward spreading or erect-spreading, in loose soft fascicles. Stem greenish to brownish, 250-500 $\mu \mathrm{m}$ in diameter, freely and regularly pinnately branched, branches of the second order rare, confined to the ends of old branches of the first order or as short gynoecial branches. Dorsal leaf lobes contiguous to imbricate, nearly plane to slightly canaliculate, obcanaliculate or loosely convex, obliquely ovate-triangular, $1.2-1.8 \times 1.2-1.0 \mathrm{~mm}$, arcuately inserted, shortly decurrent dorsally, somewhat auriculate near dorsal base, with dorsal side commonly slightly to obviously recurved, rarely (in wet places) slightly undulate, margin entire to crispate, sometimes with 1-2 teeth near ventral base or with 1-several short and obtuse teeth in the auriculate part of the dorsal base, with an obtuse to rounded apex. Ventral leaf lobes obliquely spreading, contiguous to overlapping next most distal ventral lobe, obcanaliculate (viewed from dorsal side), sometimes slightly inrolled and loosely falcate, triangularly falcate to triangular-ovate and rarely ovate when flattened, $0.6-1.0 \times 0.4-0.6 \mathrm{~mm}$, arcuately inserted, decurrent for 1.0-1.5 of stem width, margin entire or with 1 -several triangular teeth in the decurrent area. Underleaves obliquely spreading, sinuately inserted, decurrent for 1.3$2.0(-3.0)$ of stem width, concave (viewed from ventral side), underleaf body transversely elliptic to triangular-lingulate with a truncate to emarginate apex, margins recurved or not, $0.4-0.7 \times 0.6-0.8 \mathrm{~mm}$. Cells in dorsal lobe middle subisodiametric, $17-28(-30) \mu \mathrm{m}$ in diameter, cell walls thin, trigones moderate in size, concave to triangular; oil bodies 20-40 per cell, fusiform, homogenous. Dioicous. Androecia terminal, spicate, as lateral branches of the second order, without sterile unmodified leaves in the branch base, 


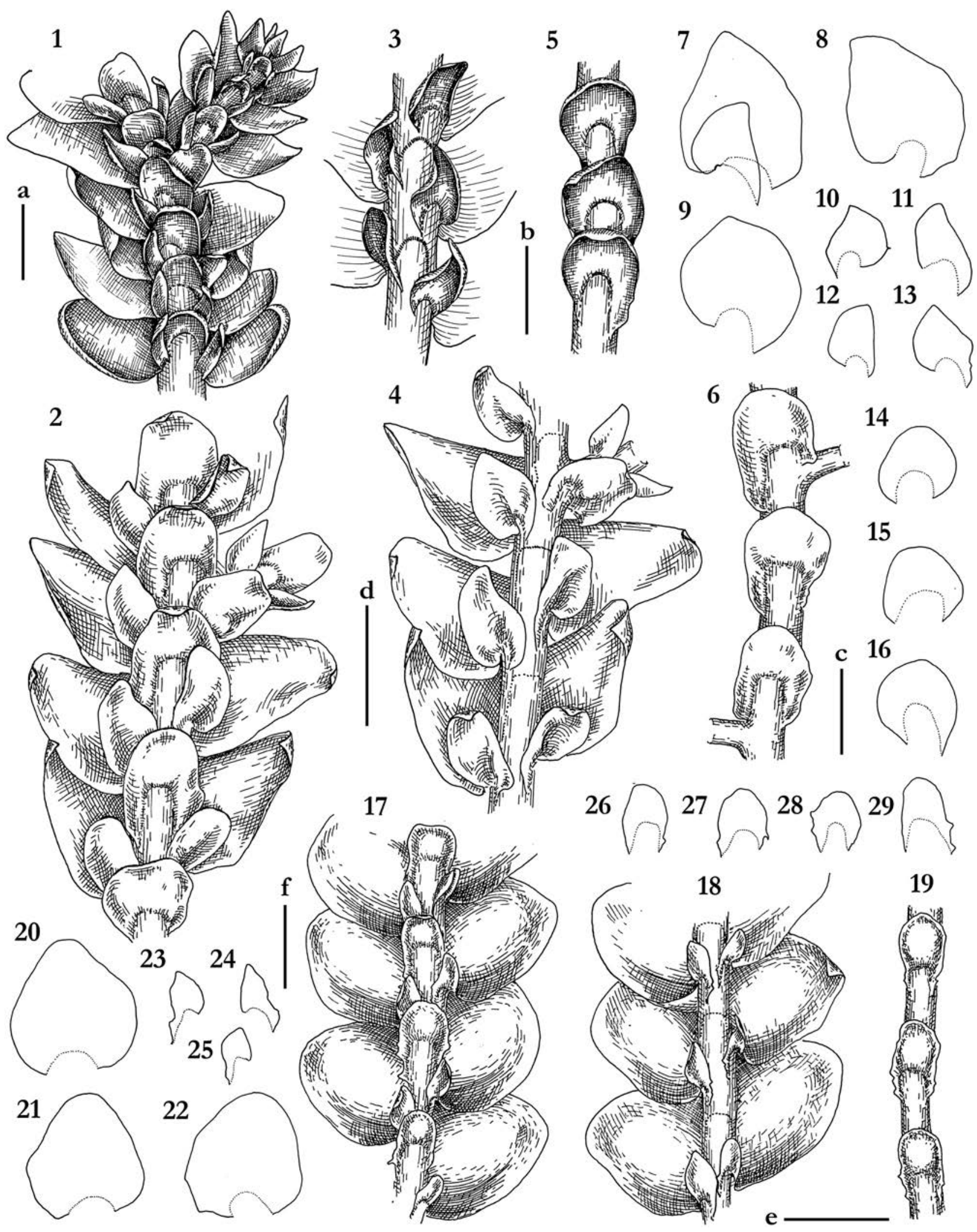

Figure 7 Porella platyphylla (L.) Pfeiff.: 1,2 - plant habit, fragment, ventral view; 3, 4-plant habit, fragment, ventral view, underleaves detached; 5, 6 - plant habit, fragment, ventral view, leaves detached; 7 - leaf; 8, 9 - dorsal lobes; $10-13$ - ventral lobes; $14-16$ - underleaves. Scales: a - 1 $\mathrm{mm}$, for 1; b-1 mm, for 3, 5; c-1 mm, for 7-16 (2, 4, 6-16 from P-63-11-11; 1, 3, 5 from Gambaryan, 26.VI.1993, VBGI). Porella cordaeana (Huebener) Moore: 17 - plant habit, fragment, ventral view; 18 - plant habit, fragment, ventral view, underleaves detached; 19 - plant habit, fragment, ventral view, leaves detached; 20-22 - dorsal lobes; 23-25 - ventral lobes; 26-29 - underleaves. Scales: d - $1 \mathrm{~mm}$, for 15-17; e - 1 $\mathrm{mm}$, for 17-19; f $-1 \mathrm{~mm}$, for 20-29 (all from M.I.107, VBGI) 
with 3-8 pairs of bracts, cupped, subequally bilobed, monoandrous, stalk very short, $50 \mu \mathrm{m}$ long or less. Gynoecia on short lateral branches of the second order; bracts entire or with 1-2 obtuse teeth in dorsal margin; perianth obovate, with truncate apex, mouth densely and sharply dentate (only unfertilized archegonia were seen from the Russian Far East). IKI reaction positive.

Variation. Plants in the Russian Far East vary much less than populations in European Russia and the Caucasus (where not so many Porella species are recorded as in the Far East; this exceeding morphological plasticity may be a consequence of adaptation to the ecological niches in which P. platyphylla never occurs in the Far East). Well developed plants in the Far Eastern populations are characterized by triangularly falcate, slightly inrolled ventral leaf lobes, which is not so characteristic (although it occurs) in the populations from the Caucasus where the ventral lobe is commonly triangular-ovate. Another specific trait of well developed plants in Far Eastern populations are somewhat canaliculate dorsal leaf lobes with slightly recurved dorsal sides - this character is present, but not dominant, in Europe and the Caucasus (leaves there are mostly slightly convex). The same may be said of variation in the leaf lobe apices. The lobe apex in the Far Eastern populations of the species is sometimes obtusely rounded (rare in European plants), resulting in several misidentification of P. platyphylla for P. subobtusa (Steph.) S. Hatt., a subtropical species differing in its glossy appearance, smaller cells, etc. that could hardly be expected in the Russian Far East. In the Russian Far East, only sterile plants and female plants with unfertilized archegonia (quite rare) are known.

Differentiation. Two regional species, P. ulophylla and $P$. chinensis, may be easily confused with $P$. platyphylla. The distinctions from the both are discussed under these species. Another species with which P. platyphylla may be mistaken is P. cordeana (Fig. 7:17-29), a taxon not known from the Russian Far East, although it may be expected here. Porella cordeana differs from $P$. platyphylla in its narrow ventral leaf lobe $(1 / 2-2 / 3$ of the stem diameter, versus ventral lobe wider than the stem) and shorter and distant ventral leaf lobes (never overlapping, contrary to $P$. platyphylla).

Ecology. Basiphilic neutro-tolerant xero-mesophyte. The preferable habitats of the species in the Russian Far East are open to partly shaded cliffs (mostly limestone). The species grows on almost open dry limestone in scattered Quercus stands (like prairie) in the southernmost flank of Primorsky Territory, as P. ulophylla sometimes does also. Besides this extreme habitat, the species grows over cliffs and stones in multidominant (in most cases including Quercus) broadleaved forests. Much more rarely, the species occurs on tree bark (at the base or above) or (one specimen only) on decaying wood, where depauperate phases are found. This differs from the ecological preferences in the Caucasus, where the species frequently grows on tree bark. P. platyphylla is not known from moist and wet habitats in the southern part of the Russian Far East, although it has been collected on the stony bank of a temporary stream in the Commander Islands, a habitat relatively similar to the species' ecology in northern Europe (like the Republic of
Karelia) where the species occurs in much wetter habitats than in the southern Far East. Within the Russian Far East, Porella platyphylla commonly forms pure mats, although it is sometimes associated with P. gracillima on limestone outcrops. The species is found from 200 to $800 \mathrm{~m}$ a.s.l., being found in lower altitude in the northern extreme of the area in the Islands. Within South Siberia and adjacent Chinese Inner Mongolia the species occupies much higher elevations, even exceeding $1700 \mathrm{~m}$ a.s.l.

Distribution. The taxon is Boreo-temperate, of nearly circumpolar distribution. In adjacent areas it is known from North-East China and the Korean Peninsula, but not from Japan. Most localities of the species in the Russian Far East lie between 43 and $45^{\circ} \mathrm{N}$. However, it easily penetrates northward to the Anyui River $\left(49^{\circ} \mathrm{N}\right)$, Komsomol'sky State $\mathrm{Na}$ ture Reserve $\left(51^{\circ} \mathrm{N}\right)$, and northwestward to the Tukuringra Range $\left(\sim 54^{\circ} \mathrm{N}\right)$, and unexpectedly appears in the Commander Islands (Mednyj Island at almost $55^{\circ} \mathrm{N}$ ), although it does not occur on the Kamchatka Peninsula. The distribution in the Commanders may be relictual, like many liverwort taxa in the Aleutian Chain (Talbot et al. 2018) (Fig. 2: 8).

Porella spinulosa (Steph.) S.Hatt., J. Hattori Bot. Lab. 33: 74, 1970. Fig. 8:1-13

Madotheca spinulosa Steph., Sp. Hepat. (Stephani) 6: 529, 1924.

Porella vernicosa f. spinulosa (Stephani) S. Hatt., Bot. Mag. (Tokyo) 57: 361, 1943

Description. Plants glistening when dry, more or less rigid, forming loose patches with Acrolejeunea sandvicensis (Gottsche) Steph., regularly pinnately branched, 40-100 $\times$ $1.7-2.5 \mathrm{~mm}$, yellowish brown to yellowish green (color probably changed due to time of keeping in the herbarium). Rhizoids virtually absent, rarely present as unclear short and thick, erect spreading fascicles originating near underleaf base. Dorsal leaf lobes imbricate, convex, strongly turned to the ventral side of the stem, when flattened on the slide obliquely ovate to slightly ovate-falcate, 1.4-1.8 × 0.9-1.2 mm, dorsal insertion line arcuate, not or scarcely decurrent, dorsal base entire to shallowly angular with obtuse teeth, dorsal side mostly entire to crispate, ventral side entire or toothed, ventral base mostly with 1-2 large prominent teeth and sometimes with some smaller additional teeth, leaf apex rounded, entire to densely toothed with teeth 3-8 cells long. Ventral leaf lobes slightly canaliculate (as seen from ventral side), $0.6-0.8 \times 0.6-0.75 \mathrm{~mm}$ (longer than wide or wider than long), arcuately inserted, not or barely decurrent, densely toothed throughout. Underleaves generally appressed to the stem proximally, but apical third commonly obliquely spreading, decurrent for $0.5-1.5$ of stem width, densely dentate with teeth larger toward the base (the largest teeth on the decurrencies), narrowly trapezoidal with a horizontally truncate, entire to loosely and shortly toothed apex. Cells in dorsal lobe middle $21-32 \times 19-27 \mu \mathrm{m}$, thin-walled, with moderate to small concave trigones, cells along dorsal side 16-21 $\mu \mathrm{m}$, walls rather thin to slightly thickened, trigones moderate in size, concave (Fig. 8). Sexual organs unknown.

Differentiation. This is a critical taxon, its status is not clear. The morphological characters of Porella spinulosa and P. vernicosa largely overlap. Hattori (1970) provides distinc- 


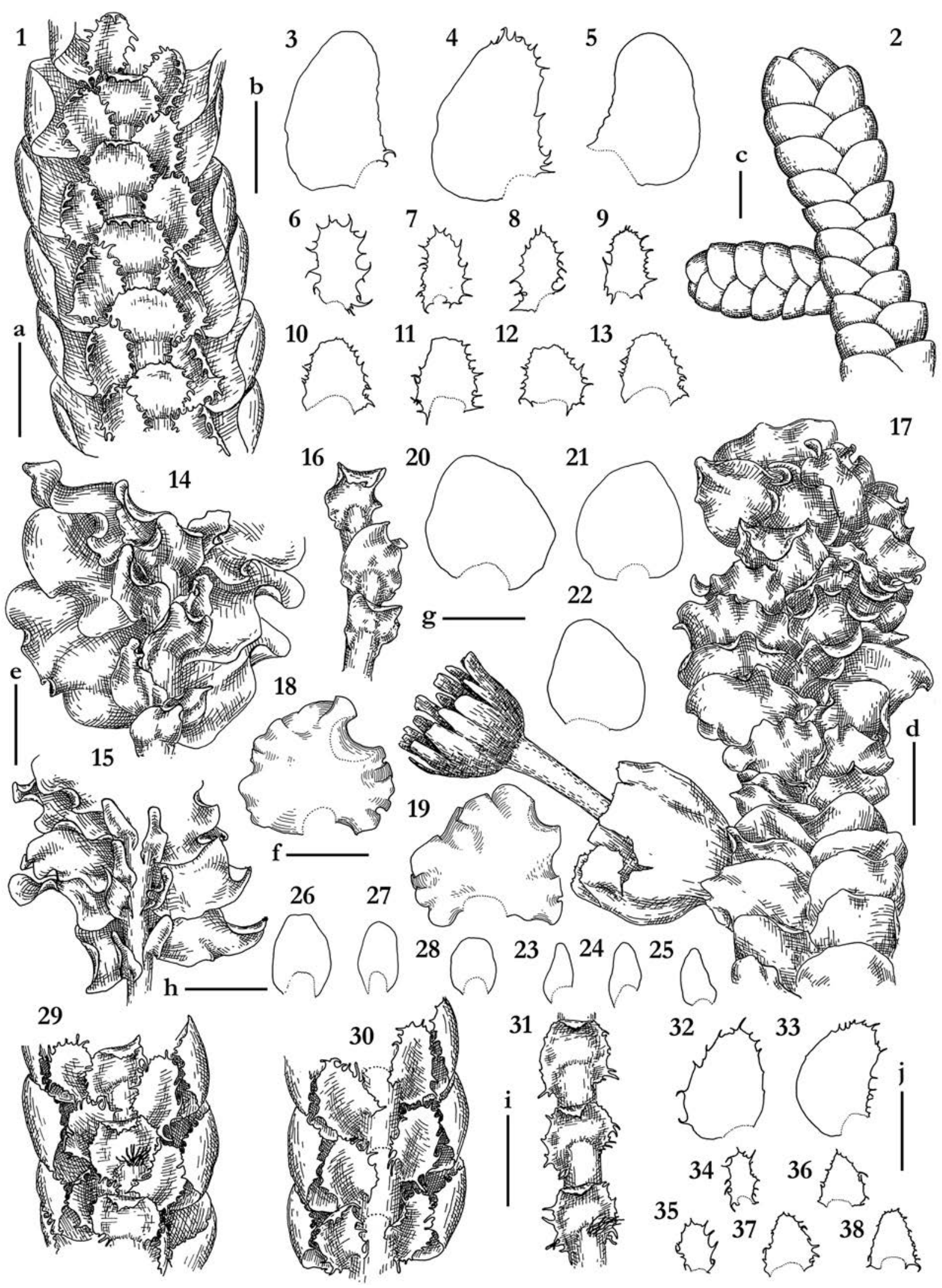

Figure 8 Porella spinulosa (Steph.) S. Hatt.: 1 - plant habit, fragment, ventral view; 2 - plant habit, fragment, dorsal view; 3-5 - dorsal lobes; 6-9 - ventral lobes; 10-13 - underleaves. Scales: a - $1 \mathrm{~mm}$, for 1; b - $1 \mathrm{~mm}$, for 3-13; c - $1 \mathrm{~mm}$, for 2 (all from G00048036/21884, G). Porella ulophylla (Steph.) S. Hatt.: 14 - plant habit, fragment, ventral view; 15 - plant habit, fragment, ventral view, underleaves detached; 16 - plant habit, fragment, ventral view, leaves detached; 17 - plant habit with sporangium, fragment, dorsal view; 18, 19 - dorsal lobes, not flattened; 20-22 - dorsal lobes; 23-25 - ventral lobes; 26-28 - underleaves. Scales: d - $1 \mathrm{~mm}$, for 17; e - $1 \mathrm{~mm}$, for 14-16; f - $1 \mathrm{~mm}$, for 18, 19; g-1 $\mathrm{mm}$, for 20-21; h-1 mm, for 25-28 (14-16, 18, 19 from Gorobets, 12.VII.2009; 20-28 from P-3-4-11, 17 from J-4-11-14, VBGI). Porella vernicosa Lindb.: 29 - plant habit, fragment, ventral view; 30 - plant habit, fragment, ventral view, underleaves detached; 31 - plant habit, fragment, ventral view, leaves detached; 32, 33 - dorsal lobes; 34,35 - ventral lobes; $36-38$ - underleaves. Scales: $i-1 \mathrm{~mm}$, for $29-31 ; j-1$ $\mathrm{mm}$, for 32-38 (all from P-73-26-11, VBGI). 
tions between two species in dorsal leaf lobe dentation and shape, and ventral leaf lobe and underleaf dentation, these characters are not all present even in the type specimen (on which the description above is based). The ventral leaf lobes in the type of P. spinulosa have long and prominent teeth that are similar to the teeth of some dorsal lobes. On the other hand, the apical dentation may be absent in some leaves of $P$. vernicosa. However, we prefer to keep the two species separate pending further research. The main argument in the favor of recognizing $P$. spinulosa as a distinct species is the fact that the leaf lobe apex is entire in weak and depauperate plants of P. vernicosa (less than $1.9 \mathrm{~mm}$ wide), and in these forms the cells of dorsal lobe middle are commonly less than 20 $\mu \mathrm{m}$ in diameter. In contrast, in P. spinulosa well developed and relatively large shoots have at least $50 \%$ of the lobe apices entire and cells larger than in even well developed P. vernicosa. The third feature is the presence (in $30-40 \%$ of leaves) of 1-2 large teeth near the dorsal leaf lobe base - this does not occur in P. vernicosa. One 'candidate' for P. spinulosa from the Far East is the specimen from Elomovsky Stream (P-68-3706) that is characterized by entire to sparsely dentate leaf lobe apices. However, it differs from the type in having much smaller cells (less than $22 \mu \mathrm{m}$ in diameter in the lobe middle). In the cell size of the leaf lobe the aforementioned specimen in somewhat similar to $P$. gracillima var. urogea, however it differs from the latter in its barely decurrent ventral leaf lobes, with teeth of nearly equal size along their margins. Moreover, the ventral base of the ventral leaf lobe does not have a prominently dentate margin, nor is it continued with paraphyllia-like teeth along the stem.

Ecology. Poorly understood, probably acidophilic mesophyte. According to data in Hattori (1970), the species grows on partially shaded, moist to (probably) mesic rocks (including tufa). One specimen (Iwato Prefecture) was probably collected on bark (given in the list with a question mark). The only record from the Russian Far East is from the southernmost part, where the species was collected on "fallen, rotten, decorticated coniferous tree trunk" (Potemkin 2008: 226). Whether the record is based on true Porella spinulosa or belongs to a weak phase of P. vernicosa could not be checked in the course of the present study. Potemkin (2008) does not provide data on the community type and the elevation where the species was collected. We may expect it was cool-temperate broadleaved forest with Abies holophylla present - a very common vegetation type in Kedrovaya Pad' State Nature Reserve. The specimen mentioned in the 'differentiation' section above (P-68-37-06) was collected on the base of a Quercus trunk in multi-dominant (broadleaved-coniferous) cool-temperate lowland forest in a stream valley, probably below $500 \mathrm{~m}$ a.s.l.

Distribution. A sporadic Korean-Japanese taxon. The records from the Russian Far East are from $43^{\circ} \mathrm{N}$, while the northernmost known record outside of Russia (Hattori 1970) comes from the vicinity of Seoul (Republic of Korea) at $37^{\circ} 30^{\prime} \mathrm{N}$.

Porella ulophylla (Steph.) S. Hatt., Bull. Tokyo Sci. Mus. 11: 92, 1944. Fig. 8:14-28

Madotheca ulophylla Steph., Bull. Herb. Boissier 5 (2): 97, 1897.
Macvicaria ulophylla (Steph.) S. Hatt., J. Hattori Bot. Lab. 5: 81, 1951 .

Description. Plants deep green to brownish green, rarely red-brown in exposed areas, yellowish in old herbarium material, $15-50 \times(2.0-) 2.5-3.5 \mathrm{~mm}$, prostrate to loosely ascending in upper part, not glistening. Stem regularly pinnately branched, 200-300 $\mu \mathrm{m}$ wide, brownish to brownish green. Rhizoids rarely present, short, originating near underleaf base, erect spreading in merely dense fascicles, densely branched very near to the end, brownish to brown and rusty brown. Dorsal leaf lobes densely imbricate, although contiguous and even distant in depauperate plants, obliquely ovate to obliquely ovate-triangular, sometimes tapered, 1.3-1.8 $\times 1.3-1.5 \mathrm{~mm}$, in robust phases sometimes widely ovate, to $1.4-1.6 \times 1.5-1.8 \mathrm{~mm}$, dorsally distinctly arcuately inserted, sometimes decurrent (to 0.5 of stem width), sometimes with 1-3 short and rarely falcate teeth near dorsal base, obliquely spreading, widest in lower $1 / 4$ $1 / 3$ of the lobe, mostly strongly crispate-undulate at the margin although plane and almost entire (not crispate) in depauperate phases, apex rounded. Ventral leaf lobes canaliculate (viewed from ventral side), canal line more or less straight or recurved, sometimes undulate and twisted, rarely almost plane, oblong-triangular or triangular to ovate, $0.4-0.7 \times 0.2-0.6 \mathrm{~mm}$, decurrent for $0.7-2.0$ of stem width, in decurrent area as a rule crispate or with 1-3 obtuse teeth, margin entire to crispate, commonly revolute, apex narrowly rounded to obtuse. Underleaves sinuately inserted, decurrent for 1.0-1.5 of stem width, nearly triangular-ovate with truncate or rounded apex, $0.7-1.0 \times 0.6-0.7 \mathrm{~mm}$, canaliculate, strongly undulate and merely crispate along margin or margin plane and entire, margin sometimes revolute. Cells in dorsal lobe middle subisodiametric, thin-walled, with moderate in size, slightly convex trigones, $25-33 \times$ 25-30 $\mu \mathrm{m}$; cuticle smooth. Androecia not seen, described by Inoue (1976). Perianths mostly on short lateral branches, rarely on main axis, without subfloral innovations, loosely dorsiventrally flattened, with 2 additional loose folds (one each on dorsal and ventral sides), 1.8-2.5 × 1.5-1.8 mm, mouth obtusely dentate; bracts and bracteole mostly crispate-undulate (but not dentate). Sporangia 1(-2) from each perianth. Seta $2.5-3.2 \mathrm{~mm}$ long, hardly exerted from the perianth. Mature and well-developed capsule 1.7-1.8 $\times$ 1.5-1.7 mm, shortly ellipsoidal, lacerate in upper half into 4-several irregular lobes. Elaters unispiral, commonly branched, 170-280 × 12-19 $\mu \mathrm{m}$, easily collapsed in the herbarium. Spores greenish, papillose, $42-50 \mu \mathrm{m}$ in diameter. IKI reaction negative (Fig. 8).

Differentiation. Commonly very easily recognizable due to its 'curly' appearance as the result of the strongly crispate-undulate dorsal leaf lobe margins. However, in some well exposed and relatively dry habitats or in depauperate phases, forms are found with almost plane margins, and these may be easily mistaken for Porella platyphylla due to the long-decurrent ventral lobes that are slightly longer than wide and ovate-triangular in shape. In this case the best way to recognize the species is the IKI reaction that is negative in P. ulophylla, but positive in P. platyphylla. Among other characters are the slightly (in the case of depauperate 
plants) crispate-undulate leaf margins of the uppermost leaves (margins plane and entire in P. platyphylla). Another taxon that may be confused with weak forms of $P$. ulophylla is $P$. chinensis; the differences are discussed under the latter.

Ecology. Indifferent mesophyte. The species prefers mesic substrata; it sometimes occurs in sunny habitats, but never occurs in wet ones. The preferable habitats are broadleaved tree bark and cliffs in open to slightly shaded places. The chemical type of rocks suitable for the species varies from limestone to acidic andesite (tufa on Miocene volcanic cones in Primorsky Territory.) Rarely, the species occurs on decaying wood. In the Russian Far East, the species occurs in multidominant broadleaved forests, more rarely spreading to monodominant Quercus forests or to Manchurian mixed forest. Sometimes it grows over limestone cliffs under very scattered oak in the communities similar to prairie in the southernmost tip of the Russian Far East (East ManchurianMountains spurs) or on bark of old trees along roadsides (in almost open conditions). Within the Russian Far East the species commonly grows in pure mats, more rarely it is mixed with Porella caespitans and Frullania spp. In northern localities it sometimes growing in partly shaded crevices of stony talus surrounded by larch-birch forest (Amur Province) or on rocky outcrops along river in birchspruce forest (Khabarovsk Territory). It grows from near sea level to $600 \mathrm{~m}$ a.s.l. The highest among the northernmost localities of the species is from Badzhal'sky Range where the species grows in a large river valley at the altitude of 600 a.s.l.

Distribution. This is a Sino-Japanese species, distributed in eastern China (to Taiwan), the Korean Peninsula, Japan and the southernmost part of the Russian Far East. Most of the known localities lie south of $45^{\circ} \mathrm{N}$ in Primorsky Territory, where the taxon is locally abundant. Northward it occurs as rarity in three mountain systems: Khingansky Range at $49^{\circ} \mathrm{N}$, Badzhal'sky Range at $50^{\circ} \mathrm{N}$ and Tukuringra Range at $54^{\circ} \mathrm{N}$. The species is not known in insular part of the Far East (Fig. 2: 6).

Porella vernicosa Lindb., Acta Soc. Sci. Fenn. 10: 223, 1872 [1873]. Fig.8:27-38

Description. Plants glossy, deep green to olive-green, sometimes yellowish green or deep brownish green in sunny places, becoming yellowish brown in the herbarium, rigid, 50-200 × 1.5-2.5 mm, sometimes with depauperate small leaved and strongly rhizogenous branches. Rhizoids virtually absent to common, originating near underleaf bases, brownish to rusty brown and red-brown, erect to obliquely (sometimes upward of the main axis) spreading, in short rigid fascicles, common on depauperate lateral branches. Stem brownish to greenish brown, 300-400 $\mu \mathrm{m}$ in diameter, irregularly (rarely regularly) pinnately branched, vegetative branches of the second order rare, but secondorder reproductive branches (male or female) common. Dorsal leaf lobes convex, strongly turned to the ventral side (both when dry and when wet), imbricate, dorsally arcuately inserted, not decurrent, obliquely ovate when flattened in the slide, apex rounded to (more rarely) obtuse to almost acute (in the leaves adjacent to gynoecia), dentate at apex, below entire to crispate at the both sides or with 1-several teeth on ventral margin and 1-2 teeth near dorsal base, 1.1$1.4 \times 0.9-1.3 \mathrm{~mm}$. Ventral leaf lobes narrowly obliquely spreading, plane or slightly convex (viewed from dorsal side), oblong lingulate to oblong ovate, variously toothed throughout, with teeth larger in the sides, $0.5-0.8 \times 0.4$ $0.5 \mathrm{~mm}$, arcuately inserted, not or barely decurrent, with apex commonly slightly turned to dorsal side. Underleaves widely trapezoidal to widely ovate-lingulate, with rounded, truncate or, rarely, shortly emarginate apex, decurrent for $0.3-1.5$ of stem width, somewhat deflexed, dentate on lateral margins and rarely also near apex, teeth longer on the basal part of the underleaf, 0.4-0.9 $\times 0.7-0.9 \mathrm{~mm}$. Cells in dorsal lobe middle subisodiametric, 12-22(-25) $\mu \mathrm{m}$ in diameter, thin-walled, trigones moderate to small, concave; cells along dorsal lobe margin somewhat subequally thickened; oil bodies in leaf dorsal lobe middle 20-30 per cell, greenish, homogenous, elliptic to fusiform, 3.5-5.0 × 2.0-3.0 $\mu \mathrm{m}$. Dioicous. Androecia spicate, terminal on the branches, with 4-10(-20) pairs of bracts, monoandrous. Gynoecia on short lateral branches of the first or the second order; bracts and bracteole dentate, dorsal and ventral lobes similar in size, bracteole sometimes with a shortly bilobed apex; perianth obtrapezoidal, dorsiventrally compressed, commonly with 2-3 additional plicae on each side, 1.7-2.0 × 2.4-2.6 mm, mouth dentate-laciniate, lacerate when capsule is mature. Capsule hidden within perianth or shortly emergent. Spores chlorophyllose, spinosely papillose, brownish greenish, 45$55 \mu \mathrm{m}$ in diameter. Elaters bispiral, 150-200 $\mu \mathrm{m}$ long and 10-15 $\mu \mathrm{m}$ wide (Fig. 8).

Variation. Probably the most common taxon of the genus in the southern part of the Russian Far East mainland, freely producing gynoecia and androecia, but the archegonia are rarely fertilized (probably due to the distance between male and female clones). The relatively wide ecological amplitude implies morphological variation that results in the amplitude in size of plants and the degree of leaf and underleaf dentation. Well developed shoots of the species are densely and prominently dentate on the dorsal leaf lobe apex and throughout the ventral lobe and at least the sides of the underleaves. However, in weak plants the dorsal leaf lobe may be almost entire (with a few obscure teeth near the apex) and the ventral lobe and underleaf margins may be only obscurely crispate. In these populations identifications should be based on well developed plants.

Differentiation. The nearest morphological ally of the species is Porella faurieri, which is also characterized by dentate and not or barely decurrent dorsal and ventral leaf lobes. The distinctions may be found in underleaf shape and 'dentation' type, as discussed under P. faurieri. These two taxa are separated geographically, with $P$. vernicosa being more continental (not known in Sakhalin and Kurils), whereas $P$. faurieri mostly grows under oceanic conditions, although it occurs in some mountainous lands adjacent to the sea coast in Primorsky Territory wetted by monsoon air masses coming from the sea. Another taxon with which confusion is possible is the critical P. spinulosa-distinctions are discussed under the latter.

Ecology. Neutrophilic acido- and calcium-tolerant xeromesophyte. Growing in broadleaved or mixed broadleaved- 
coniferous forests of hemiboreal and cool-temperate zones (southward occuring in the warm temperate zone in forests with common broadleaved evergreen trees). In northern localities (Khabarovsk Territory) it grows in lowland dark coniferous (spruce-fir) forests. The most common habitats are bases of broadleaved trees, rarely growing above the tree butt up to 1-2 $\mathrm{m}$ above the ground, and never collected from the bark of conifers. Relatively rarely, although regularly, it occurs over stones, boulders and cliffs of neutral reaction (once it was also collected on limestone) at the distance or near the watercourses (but not very close to the water). The species prefers slightly shaded places, although it tolerates full sun in some areas; then it acquires deep brownish green pigmentation. Like other Porella species, P. vernicosa usually grows in pure patches, although it is sometimes associated with other hepatics, like Barbilophozia barbata, Frullania davurica Hampe ex Gottsche, F. taradakensis, Metzgeria pubescens, Porella caespitans, and P. grandiloba. Southward (on the Korean Peninsula), it occurs with Frullania moniliata (Reinw., Blume et Nees) Mont., Plagiochila sciophila Nees and Porella japonica (Sande Lac.) Mitt. The species grows from near sea level to middle elevations, with one exceptional case at high elevation (1500 m a.s.l. in Olkhovaya Mt.). This species seems to show a similar pattern on the Korean Peninsula, where it seldom grows above $1000 \mathrm{~m}$ a.s.l.

Distribution. An East Asian species, with a distribution covering North-East China (southward to Henan Province), the Korean Peninsula, Japan, the southernmost part of Eastern Siberia and the southern part of the continental Russian Far East. The species is common in the southern part of the area treated, from numerous islands of the Peter the Great Bay inland to middle Sikhote-Alin Mts. Northward it becomes rarer, although it penetrates to the Tardoki-Yani Range in northern Sikhote-Alin Mts., Khabarovsk City surroundings $\left(48^{\circ} \mathrm{N}\right)$, Anyui River Basin $\left(49^{\circ} \mathrm{N}\right)$ and Badzhal'sky Range $\left(50^{\circ} \mathrm{N}\right)$ (Fig. 2: 7).

\section{ERRONEOUS REPORTS}

Porella cordaeana (Bakalin 2010) - misidentification of a poorly developed phase of P. platyphylla.

Porella decurrens (Steph.) Parihar (Bakalin 2010) - misidentification of P. platyphylla.

Porella densifolia (Gambaryan 1992, Konstantinova et al. 2009, Bakalin 2010) - misidentifications of P. grandiloba and P. platyphylla.

Porella nitens (Steph.) S. Hatt. (Konstantinova et al. 2009, Bakalin 2010, Bakalin et al. 2012) - misidentification of P. grandiloba.

Porella nitidula (C. Massal.) S. Hatt. (Konstantinova et al. 2009, Bakalin 2010) - misidentification of P. grandiloba.

Porella tenera H. Hara (Bakalin 2010) - misidentification of P. platyphylla.

Porella tosana (Steph.) S. Hatt. (Konstnatinova et al. 2009, Bakalin 2010) - misidentification of P. oblongifolia.

\section{DISCUSSION}

The only circumpolar species of Porella known in the Russian Far East is P. platyphylla, all other taxa have 'area core' in East Asia. Some of them are widely spreading as far as South Siberia (Porella gracillima) or the Aleutians ( $P$. faurier $)$ or are broadly East-South-Southeast Asian, like P. caespitans representing one of the most southern elements in the Far Eastern liverwort flora. Porella obtusata f. obtusata distriburted in Europe and P. gracillima s.l. known in North America.

Porella is taxonomically rich in the tropics and subtropics, the Russian Far East is on the northern edge of its range in Asia (with some exclusions e.g. for $P$. platyphylla). The northernmost ocurrence known is Porella platyphylla $\left(54^{\circ} \mathrm{N}\right.$ in the Commanders). In the Russian Far East, most Porella taxa are known from the south-east fringe of the mainland part: southern Primorsky Territory. Only a few species penetrate northwestward to Amur Province and Khabarovsk Territory. Only three taxa (Porella faurieri, P. gracillima and P. grandiloba) are known from the islands of the southern Russian Far East. The distribution of P. obtusata var. macroloba in Amur Province has a distinctive relict character. The latter taxon belongs to a group of eastern Paleo-Tethian ancient relicts that include a number of xeric species.

Porella species seldom produce sporophytes in the Russian Far East. Gynoecia and androecia occur regularly in some species, but are not known in some others. Mature perianths are rare in the region. In the Russian Far East, five species have been collected with sporangia: Porella ulophylla, P. chinensis, P. faurieri, P. grandiloba, P. vernicosa; two species have never been collected with gynoecia, $P$. caespitans (only one specimen with androecia is known) and P. obtusata; and two species are not known with androecia: $P$. gracillima (known with gynoecia) and P. oblongifolia (once found with gynoecia). $P$. platyphylla is known with gynoecia and androecia but its gynoecia were never found fertilized.

\section{ACKNOWLEDGEMENTS}

The author is deeply indebted to Mr. Matvei Bakalin for providing figures for the present paper, Mr. Daniil Bakalin for software preparation for producing the maps, Dr. Sergey Dudov (MW) for providing Porella specimens collected in Tukuringra Range and to Dr. Pavel Krestov (VBGI) for collecting the specimen of Porella obtusata var. macroloba. Authors are grateful to curators of MO, F, G, KPABG, MHA and CAS who makes study of some of cited specimens possible. Besides, authors are very grateful to three anonymous reviewers for their constructive criticism and language improvements. The work was partially supported by the grants of the Russian Foundation for the Basic Researches (15-34-20101 and 17-04-00018).

\section{LITERAT URE CITED}

Bakalin, V. A. 2010. The distribution of bryophytes in the Russian Far East. Part. 1. Hepatics. Izdatel'stvo Dal'nevostochnogo Federal'nogo Universiteta, Vladivostok, 175 pp. (in Russian and English). [Бакалин В.А. 2010. Распространение мохообразных на Аальнем Востоке России. Часть 1. Печеночники. ВАадивосток: Издательство Аальневосточного Федерального университета, 175 с.].

Bakalin, V.A., O.Yu. Pisarenko, V.Ya. Cherdantseva, P.V. Krestov, M.S. Ignatov \& E.A. Ignatova 2012. Bryophytes of Sakhalin. Izdatel'stvo Morskogo gosuniversiteta, Vladivostok, 310 pp. (in Russian) [Бакалин B.А., Писаренко О.Ю., Черданцева В.Я., Крестов П.В., Игнатов М.С., Игнатова Е.А. 2012. Бриофмора Сахалина. Вцадивосток: ИзА-во Морского госуниверситета, 2012. 310 с.]. 
Damsholt, K. 2002. Illustrated flora of Nortdic Liverworts and Hornworts. Lund, Nordic Bryological Society, 837 pp.

Gambaryan, S.K. 1992. The liverworts and hornworts of Southern Primorye. Vladivostok, Dal'nauka, 172 pp. (in Russian). ГГамб̆арян С.К. 1992. Антоцеротовые и печеночники Южного Приморья. ВАадивосток, Аальнаука. С. 172].

Frey, W. \& M. Stech 2009. Marchantiophyta, Bryophyta, Anthocerotophyta. In: Syllabus of Plant Families (W. Frey, ed.), pp. 1-257, Borntraeger, Stuttgart.

Hara, H. 1956. A review of Porella from Shikoku, southern Japan. Research reports of Kochi University 4(12):1-27.

Hassel, K., J.I. Johnsen, J.B. Jordal \& A. Knutsen 2015. Porella obtusata: distribution, ecology and threats at the west coast of Norway, the northern fringe of its European distribution. Lindbergia 38:30-38.

Hattori, S. 1967. Studies on Asiatic species of the genus Porella (Hepaticae). I. Some little known Asiatic species of Porella. Journal of the Hattori Botanical Laboratory 30: 129-151.

Hattori, S. 1970. Studies on Asiatic species of the genus Porella (Hepaticae). III. Journal of the Hattori Botanical Laboratory 33: 41-87.

Hattori, S. 1971. Studies on Asiatic species of the genus Porella (Hepaticae). IV. Journal of the Hattori Botanical Laboratory 34:411-428.

Hattori, S. 1978. Studies on Asiatic species of the genus Porella (Hepaticae). VII. A synopsis of Asiatic Porellaceae. Journal of the Hattori Botanical Laboratory 44:91-120.

Inoue, H. 1976. Illustrations of Japanese Hepaticae. Tokyo, 194 pp.

Hentschel, J., R.-L. Zhu, D.G. Long, P.G. Davison, H. Schneider, Gradstein S.R., Heinrichs J. 2007. A phylogeny of Porella (Porellaceae, Jungermanniopsida) based on nuclear and chloroplast DNA sequences. Molecular Phylogenetics and Evolution 45:693-705.

Konstantinova, N.A. \& V.A. Bakalin with contributions on regional floras from E.N. Andrejeva, A.G. Bezgodov, E.A. Borovichev, M.V. Dulin, Yu.S. Mamontov 2009. Checklist of liverworts (Marchantiophyta) of Russia. Arctoa 18:1-64.

Lindberg, S.O. 1872. Contributio ad floram cryptogamam Asiae boreali-orientalis. Acta Societatis Scientiarum Fennicae 10:221-280.
Paton, A.J. 1999. The liverwort Flora of the British Isles. Harley Books, Colchester, 626 pp.

Piippo, S. 1990. Annotated catalogue of Chinese Hepaticae and Anthocerotae. Journal of the Hattori Botanical Laboratory 68:1-192.

Potemkin, A.D. 2008. New liverwort records from Primorsky Territory. 3. Arctoa 17:226.

Potemkin, A.D., Y.S. Mamontov, E.A. Borovichev, V.E. Fedosov \& E.V. Sofronova 2015. The genus Ascidiota C. Massal. (Porellaceae, Marchantiophyta) in North Asia. Journal of Bryology 37(1):49-55.

Schljakov, R.N. 1982. The liverworts and hornworts of the North of the USSR, vol. 5. Leningrad, Nauka, 196 pp. (in Russian) Ш Шяков P.Н. 1982. Печеночные мхи Севера СССР, вып. 5. АенинграА: Наука, 196 с.].

Schumacker, R. \& J. Váňa 2005. Identification keys to the liverworts and hornworts of Europe and Macaronesia, ed. 2. Sorus, Poznań, 209 pp.

Söderström, L., A. Hagborg, M. von Konrat, S. BartholomewBegan, D. Bell, L. Briscoe, E. Brown, D.C. Cargill, D.P. Costa, B.J. Crandall-Stotler, E.D. Cooper, G. Dauphin, J.J. Engel, K. Feldberg, D. Glenny, S.R. Gradstein, X. He, J. Heinrichs, J. Hentschel, A.L. Ilkiu-Borges, T. Katagiri, N.A. Konstantinova, J. Larran, D.G. Long, M. Nebel, T. Pôcs, F. Felisa Puche, E. Reiner-Drehwald, M.A.M. Renner, A. Sass-Gyarmati, A. Schâfer-Verwimp, J.G.S. Moragues, R.E. Stotler, P. Sukkharak, B.M. Thiers, J. Uribe, J. Váňa, J.C. Villarreal, M. Wigginton, L. Zhang \& R.-L. Zhu 2016. World checklist of hornworts and liv erworts. PhytoKeys 59:1-828.

Steere, W.C. \& R.M. Schuster 1960. The hepatic genus Ascidiota Massalongo new to North America. Bulletin of the Torrey Botanical Club 87(3):209-215.

Steere, W.C. \& H. Inoue 1978. Hepaticae of Arctic Alaska. Journal of the Hattori Botanical Laboratory 44: 251-345.

Stephani, F. 1909-1912. Species Hepaticarum, vol. 4. Geneve et Bale, 824 pp.

Talbot S.S., W.B. Schofield, J. Váňa \& S.L. Talbot 2018. Liverworts from Attu Island, Near Islands, Aleutian Islands, Alaska (USA) with comparison to the Commander Islands (Russia). Botanica Pacifica 7(2): 127-141.

\section{SPECIMENS EXAMINED}

Ascidiota blepharophylla C.Massal.

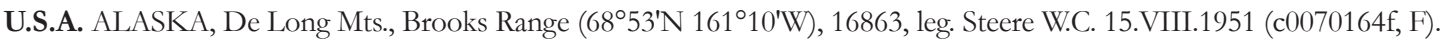

Porella caespitans (Steph.) S.Hatt.

JAPAN. AICHI PREF., Tengudana, 16437, leg. Takaki N. 31.VII.1955 (VBGI), Tsunemichi, 6145, leg. Takaki N. $24 . I V .1949$ (VBGI),

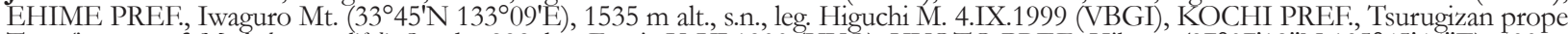
Tosa (isotype of Madotheca cordifolia Steph., 892, leg. Faurie U. VI.1900 (KYO), KYOTO PREF., Kibune (370 $\left.07^{\prime} 18^{\prime \prime N} 135^{\circ} 45^{\prime} 46^{\prime \prime} \mathrm{E}\right), 400 \mathrm{~m}$ alt., J-3-20-14, leg. Bakalin V.A. 22.II.2014 (VBGI), NARA PREF., Odaigahara Mt., 5020, leg. Takaki N. 3.VIII.1948 (VBGI), SHIZUOKA PREF., Ozama (isotype of Madotheca setigera Steph.), 15286, leg. Faurie U. II.1895 (KYO). REPUBLIC OF KOREA. GANGWON

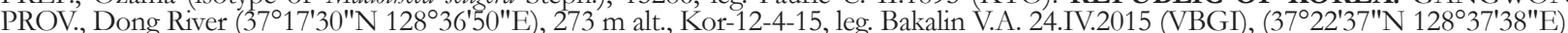
$402 \mathrm{~m}$ alt., Kor-21-9-15, leg. Bakalin V.A. 26.IV.2015 (VBGI), JEJU PROV., Halla Mt. (33¹8'30"N 126³0'30"E), 700 m alt., Kor-291-15, leg. Bakalin V.A. 13.V.2015 (VBGI), JEOLLABUK PROV., (3546'57"N 12942'46"E), $810 \mathrm{~m}$ alt., Kor-16-1-08, leg. Bakalin V.A. 
30.VII.2008 (VBGI), (3551'59"N 12943'07"E), 690 m alt., Kor-17-47-08, leg. Bakalin V.A. 1.VII.2008 (VBGI), GYEONGNAM PROV.,

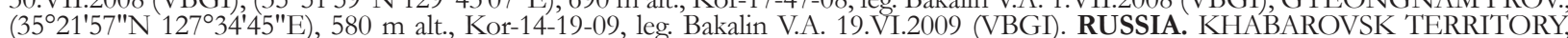
Anyui River $\left(49^{\circ} 22^{\prime} 36^{\prime \prime N} 137^{\circ} 43^{\prime} 11^{\prime \prime E}\right), 200 \mathrm{~m}$ alt. Kh-72-2-09, leg. Bakalin V.A. 21.IX.2009 (VBGI), (49²2'36"N 137²4'11"E), 202 $\mathrm{m}$ alt., Kh-72-27-09, leg. Bakalin V.A. 21.IX.2009 (VBGI, Bol'shekhekhtsirsky State Nature Reserve, $300 \mathrm{~m}$ alt. s.n. leg. Gambaryan S.K. 24.VII.1975 (VBGI), PRIMORSKY TERRITORY, Baranovskogo Miocene Volcano (433' $\left.01^{\prime \prime N} 131^{\circ} 55^{\prime} 02^{\prime \prime} \mathrm{E}\right), 100 \mathrm{~m}$ alt., P-1-4-

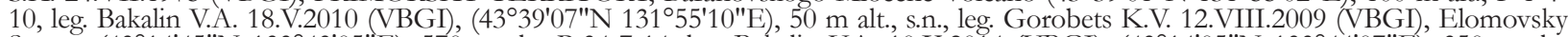

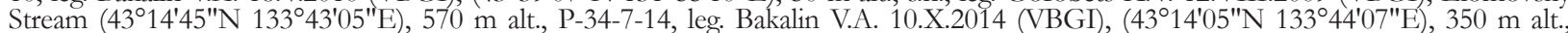

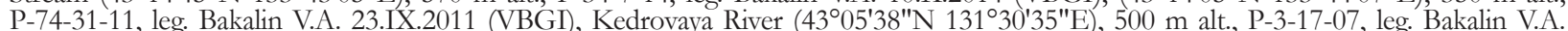

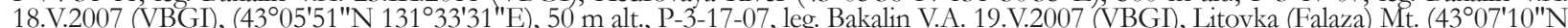

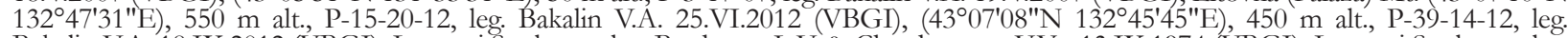
Bakalin V.A. 18.IX.2012 (VBGI), Lozovyi Settl., s.n., leg. Bardunov L.V. \& Cherdantseva V.Ya. 13.IX.1974 (VBGI), Lozovyi Settl., s.n., leg. Bardunov L.V. \& Cherdantseva V.Ya. 13.IX.1974 (VBGI), Lozovyi (Chandolaz) Range (4301'43"N 13301'24"E), 300 m alt., P-69-8-06, leg. Bakalin V.A. 7.X.2006 (VBGI), Razdol'nava River (4338'59"N 13155'09"E), 35 m alt., Prim-17-6-16, leg. Klimova K.G. \& Bakalin V.A. 16.X.2016 (VBGI), Sestra Mt. (4249'39"N 13259'38"E), $300 \mathrm{~m}$ alt., P-47-27-08, leg. Bakalin V.A. 14.VIII.2008 (VBGI), (4249'39"N $\left.132^{\circ} 59^{\prime} 40^{\prime \prime E}\right), 320 \mathrm{~m}$ alt., P-69-13-08, leg. Bakalin V.A. 17.X.2008 (VBGI), Shkotovo Settl., s.n., leg. s.d. IX.1926 (VBGI), Sinyaya Mt.

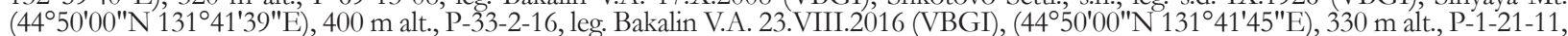

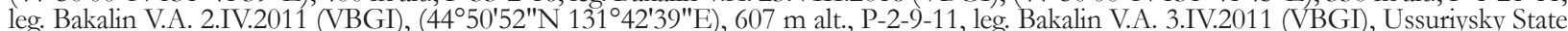

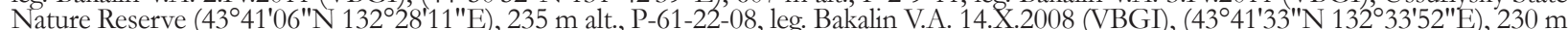
alt., P-68-24-08, leg. Bakalin V.A. 16.X.2008 (VBGI), s.n., leg. Cherdantseva V.Ya. 9.VII.1974 (VBGI), s.n., leg. Komarov V.L. 17.VIII.1930

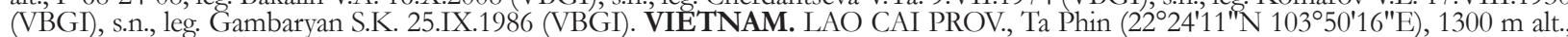
V-4-33-16, leg. Bakalin V.A. 18.III.2016 (VBGI).

Porella chinensis (Steph.) S.Hatt.

CHINA. YUNNAN PROV., Maculchan (holotype of Madotheca cbinensis Steph.), $3500 \mathrm{~m}$ alt., leg. Delavay J.M. 23.X.1889 (G00043966/ 12601). RUSSIA. AMUR PROV., Khingansky Reserve, s.n., leg. Gambaryan S.K. 18.VII.1991 (VBGI), KHABAROVSK TERRITORY, Bol'shekhekhtsirsky State Nature Reserve, s.n., leg. Cherdantseva V.Ya. 9.VIII.1981 (VBGI), PRIMORSKY TERRITORY, Avvakumovka River (4351'42"N 13458'35"E), 159 m alt., P-85-2-07, leg. Bakalin V.A. 22.IX.2007 (VBGI), (4259'48"N 13300'11"E), 470 m alt., P-754a-05, leg. Bakalin V.A. 18.X.2005 (VBGD, 660 m alt., s.n., leg. Gambaryan S.K. 11.IX.1980 (VBGI), Krasnoarmeisky District, s.n. leg. 4a-05, leg. Bakalin V.A. 18.X.2005 VBGI), $660 \mathrm{~m}$ alt., s.n., leg. Gambaryan S.K. 11.IX.1980 (VBGI), Krasnoarmeisky District, s.n., leg.

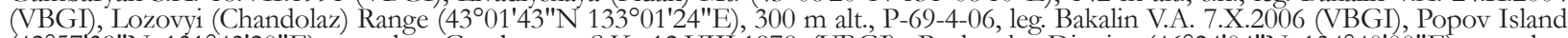
(42 $57^{\prime} 39^{\prime \prime} \mathrm{N} 131^{\circ} 43^{\prime} 20^{\prime \prime E}$ ), s.n., leg. Gambaryan S.K. 12.VIII.1978 (VBGI), Pozharsky District $\left(46^{\circ} 24^{\prime} 04^{\prime \prime N} 134^{\circ} 40^{\prime} 00^{\prime \prime E}\right)$, s.n., leg. Gambaryan S.K. 26.VI.1993 (VBGI), s.n. leg. Gambarvan S.K. 24.VI.1993 (VBGI, s.n., leg. Gambaryan S.K. 28.VI.1993 (VBGI), SikhoteAlinsky State Nature Reserve, s.n., leg. Doronina Yu.A. 14.VIII.1976 (VBGI), Ussuriysky State Nature Reserve, s.n., leg. Semin X.1914 (VBGI), Verkhne-Ussuriysky Scientific Station, s.n., leg. Cherdantseva V.Ya. 29.VIII.1974 (VBGI), s.n., leg. Gambaryan S.K. 26. VI.1976 (VBGI), Vladivostok City, s.n., leg. Voroshilov V.N. 28.IX.1950 (VBGI).

Porella cordaeana (Huebener) Moore

U.S.A. OREGON, Eagle Mt., 1100 m alt., M.I.107, leg. Ignatov M.S. 14.VIII.1989 (M.I.107, VBGI).

Porella densifolia (Steph.) S.Hatt.

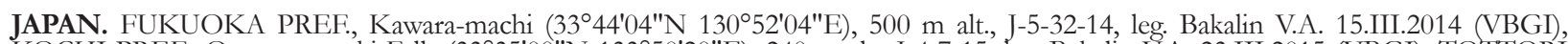

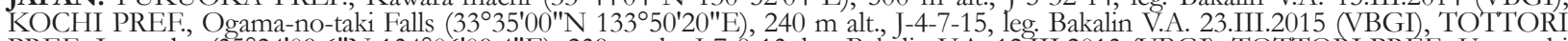
PREF., Iwatsubo $\left(35^{\circ} 24^{\prime} 09.6^{\prime \prime N} 134^{\circ} 06^{\prime} 09.4^{\prime} E\right), 239 \mathrm{~m}$ alt. J-7-8-13, leg. Bakalin V.A. 12.III.2013 (VBGI), TOTTORI PREF., Ue-machi $\left(35^{\circ} 30^{\prime} 05^{\prime \prime N} 134^{\circ} 15^{\prime} 00^{\prime \prime E}\right), 60 \mathrm{~m}$ alt. J-1-21-13, leg. Bakalin V.A. 10.III.2013 (VBGI). REPUBLIC OF KOREA. GANGWON PROV. (37019'24"N 12900'18"E), 660 m alt., 7006, leg. Choi S.S. 14.X.2009 (VBGI).

\section{Porella faurieri (Steph.) S.Hatt.}

REPUBLIC OF KOREA. GANGWON PROV., Seorak Mts. (3808'11"N 128²8'24"E), $900 \mathrm{~m}$ alt., Kor-11-02-11, leg. Bakalin V.A.

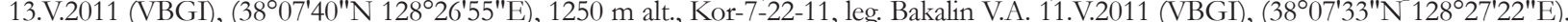
$1550 \mathrm{~m}$ alt., Kor-9-25-11, leg. Bakalin V.A. 12.V.2011 (VBGD, JEOLLABUK PROV. (3550'12"N 12744'24"E), $1330 \mathrm{~m}$ alt. Kor-10-29-

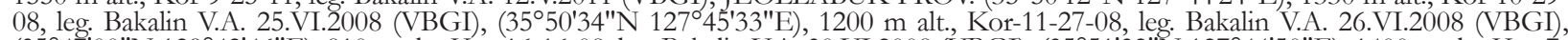
$\left(35^{\circ} 47^{\prime} 00^{\prime \prime N} 129^{\circ} 42^{\prime} 46^{\prime \prime E}\right.$ ), $810 \mathrm{~m}$ alt., Kor-16-16-08, leg. Bakalin V.A.30.VI.2008 (VBGI), (3551'32"N $127^{\circ} 44^{\prime} 50^{\prime \prime E}$ ), $1400 \mathrm{~m}$ alt., Kor-7' 9-08, leg. Bakalin V.A. 24.VI.2008 (VBGI, GYEONGNAM PROV. (35¹9'55"N 127²43'55"E), $1650 \mathrm{~m}$ alt., Kor-12-4-09, leg. Bakalin V.A.

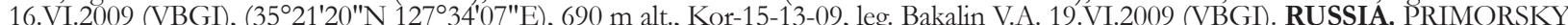
TERR., Bol'shoi Pelis Island, s.n., leg. Gambaryan S.K. 20.VIII.1995 (VBGI), Elomovsky Stream (43¹4'45"N 13343'05"E), 570 m alt., P-34-9-14, leg. Bakalin V.A. 10.IX.2014 (VBGI), Kaban'ya Mt. (4353'58"N $\left.135^{\circ} 02^{\prime} 42^{\prime \prime E}\right), 150 \mathrm{~m}$ alt., P-9-8-14, leg. Bakalin V.A. 2.VII.2014 (VBGI), Kedrovaya River $\left(43^{\circ} 05^{\prime} 38^{\prime \prime N} 131^{\circ} 30^{\prime} 35^{\prime \prime E}\right), 500 \mathrm{~m}$ alt., P-3-42-07, leg. Bakalin V.A. 18.V.2007 (VBGI), Litovka (Falaza) Mt.

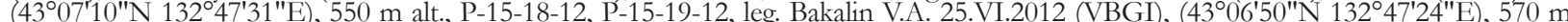

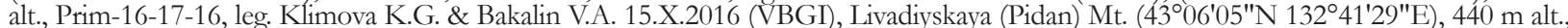
P-52-7-08, leg. Bakalin V.A. 6.X.2008 (VBGI), Milogradovka River (43⒉ $\left.6^{\prime} 32^{\prime \prime} \mathrm{N} 134^{\circ} 13^{\prime} 20^{\prime \prime} \mathrm{E}\right), 800 \mathrm{~m}$ alt., P-45-18a-12, leg. Bakalin V.A.

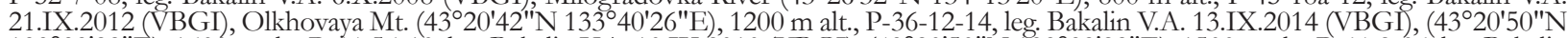
$\left.133^{\circ} 39^{\prime} 22^{\prime \prime E}\right), 1600 \mathrm{~m}$ alt., P-44-56-10, leg. Bakalin V.A. 10.IX.2010 (VBGI), (4320'50"N 13339'22"E), $1500 \mathrm{~m}$ alt., P-64-8-06, leg. Bakalin

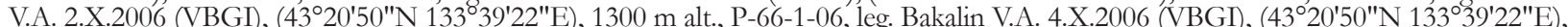
$1300 \mathrm{~m}$ alt., P-66-3a-06, leg. Bakalin V.A. 4.X.2006 (VBGI), SAKHALIN PROV., «Kimonai», 120, leg. Faurie U. 21.IX.1908 (KYO), Anna

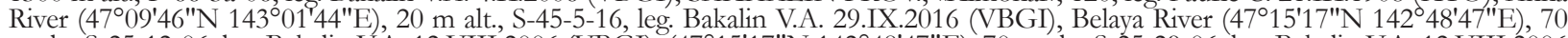
$\mathrm{m}$ alt. S-25-12-06, leg. Bakalin V.A. 12.VIII.2006 (VBGI), (47015'17"N 142 48'47"E), $70 \mathrm{~m}$ alt. S-25-29-06, leg. Bakalin V.A. 12.VIII.2006

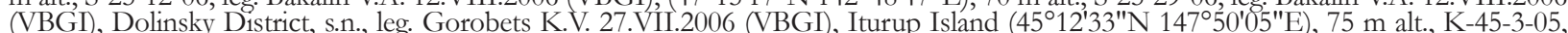

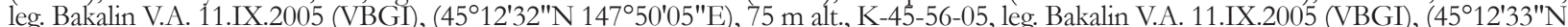
$\left.147^{\circ} 50^{\prime} 05^{\prime \prime E}\right), 75 \mathrm{~m}$ alt., K-45-7-05, leg. Bakalin V.A. 11.IX.2005 (VBGI), (4514'48"N 14800'51"E), $25 \mathrm{~m}$ alt., K-61-24-05, leg. Bakalin

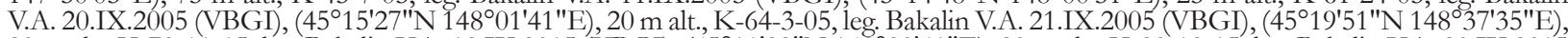
$20 \mathrm{~m}$ alt., K-73-11-15, leg. Bakalin V.A. 13.IX.2015 (VBGI), (4511'28"N'148'20'41"E), $20 \mathrm{~m}$ alt., K-80-18-15, leg. Bakalin V.A. 20.IX.2015

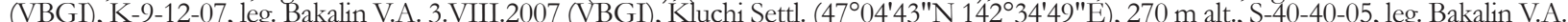
4.IX.2005 (VBGI), Kunashir Island $\left(44^{\circ} 29^{\prime} 07 » N\right.$ 146 $05^{\circ} 57 »$ E), $38 \mathrm{~m}$ alt., K-36-18-06, leg. Bakalin V.A. 27.VIII.2006 (VBGI), (44²27'41"N

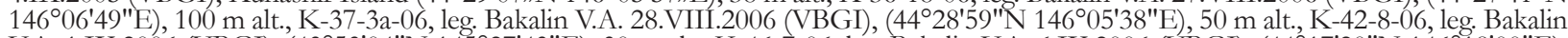

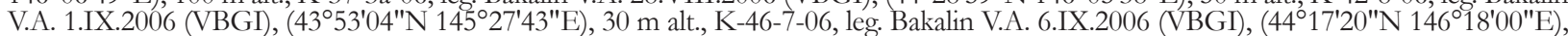
$40 \mathrm{~m}$ alt., K-56-11-06, leg. Bakalin V.A. 12.IX.2006 (VBGI), Mavorskava Mt. (4653'17"N 14256'03"E), 320 m alt., S-39-9-05, leg. Bakalin VA. 3.IX 2005 (VBGI, Mereva River (46⒊'24"N 142 54'05"E) 6 m alt S-24-14-06, leg. Bakalin VA. 11.VIII.2006 (VBGI), Nevelsky

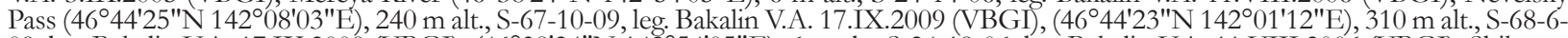
09, leg. Bakalin V.A. 17.IX.2009 (VBGI), (46³8'24"N 142 54'05"E), 6 m alt., S-24-19-06, leg. Bakalin V.A. 11.VIII.2006 (VBGI), Shikotan

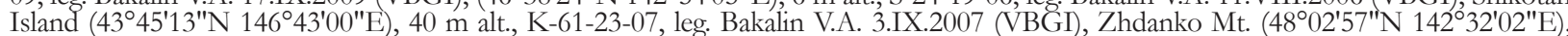
$540 \mathrm{~m}$ alt., S-24-8-09, leg. Bakalin V.A. 20.VIII.2009 (VBGI), (4805'28"N 142³1'30"E), $200 \mathrm{~m}$ alt., S-48-9-16, leg. Bakalin V.A. 1.X.2016 (VBGI), s.n., leg. Faurie U. 1908 (KYO). 


\section{Porella gracillima Mitt.}

CHINA. INNER MONGOLIA PROV., Great Khingansky Range (44¹1'44"N 11843'27"E), 1500 m alt., China-27-7-10, leg. Bakalin V.A. 2.VIII.2010 (VBGI), (435'16"N $\left.11^{\circ} 31^{\prime} 11^{\prime \prime E}\right), 1760 \mathrm{~m}$ alt. China-35-6-10, leg. Bakalin V.A. 6.VIII.2010 (VBGI). RUSSIA. AMUR

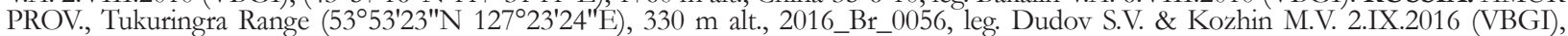
IRKUTSK PROV., Utulik River (51 $31^{\prime} 15^{\prime \prime N} 104^{\circ} 02^{\prime} 55^{\prime \prime E), ~} 460 \mathrm{~m}$ alt., 213213, leg. Melick H. van 15.IX.2010 (VBGI), KHABAROVSK TERR., Anyui River (49²2'36"N 13743'11"E), $200 \mathrm{~m}$ alt., Kh-72-14-09, leg. Bakalin V.A. 21.IX.2009 (VBGI), PRIMORSKY TERR., Bol'shoi Pelis Island, s.n., leg. Gambaryan S.K. 20.VIII.1995 (VBGI), (4301'43"N 13301'24"E), 300 m alt., P-69-21-06, leg. Bakalin V.A.

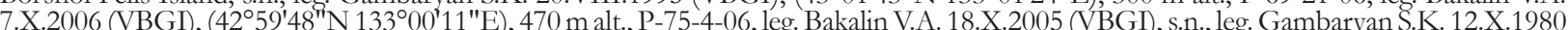
(VBGI), s.n., leg. Cherdantseva V.Ya. 26.VIII.2007 (VBGI), Dalnegorsk Town (44³4'50"N 135'32'58"'E), 470 m alt., P-37-7-16, leg. Bakalin V.A. 26.VIII.2016 (VBGI), (44³5'12"N 135³3'24"E), 505 m alt., P-63-2-11, leg. Bakalin V.A. 15.IX.2011 (VBGI), Elomovsky Stream

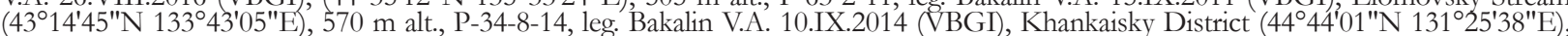
$461 \mathrm{~m}$ alt., P-3-2-11, leg. Bakalin V.A. 4.IV.2011 (VBGI), Krasnoarmeisky District, H-1945, leg. Gambaryan S.K. 17.VI.1991 (VBGI), Lazovsky State Nature Reserve, s.n., leg. Gambaryan S.K. 1.X.1986 (VBGI, Lozovyi (Chandolaz) Range (4301'43"N 13301'24"E), 300 m alt., P-69-21-06, leg. Bakalin V.A. 7.X.2006 (VBGI), Ol'ginsky District (4352'27"N 135¹4'07"E), 116 m alt., P-11-2-14, leg. Bakalin V.A. 3.VII.2014 (VBGI), Partizansk town, s.n., leg. Komarov V.L. 6.IX.1913 (VBGI), Przhevalskogo Range (4351'30"N $132^{\circ} 28^{\prime} 36^{\prime \prime E}$ ), 230 m alt., P-6-4-10, leg. Bakalin V.A. 3.VI.2010 (VBGI), Sestra Mt., 213163, leg. Melick H. van 7.IX.2010 (VBGI), (4249'39"N 13259'38"E), 300 $\mathrm{m}$ alt., P-47-21-08, leg. Bakalin V.A. 14.VIII.2008 (VBGI), (4249'39"N 13259'40"E), 320 m alt., P-69-13-08, leg. Bakalin V.A. 17.X.2008

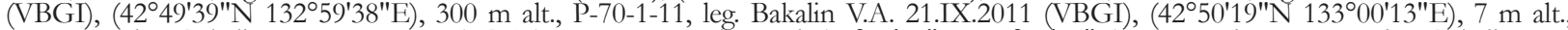
P-71-1-08, leg. Bakalin V.A. 17.X.2008 (VBGI), Starovarvarovka Settl. (4351'55"N 13255'33"E), 180 m alt., P-3-1-10, leg. Bakalin V.A. 3.VI.2010 (VBGI), Ussuriysky State Nature Reserve (4338'30"N 132 33'16"E), 330 m alt., P-63-9-08, leg. Bakalin V.A. 15.X.2008 (VBGI),

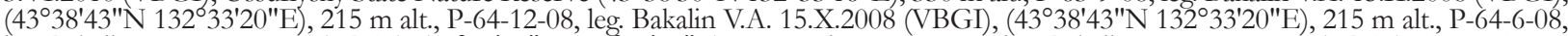
leg. Bakalin V.A. 15.X.2008 (VBGI), (434' $\left.33^{\prime \prime N} 132^{\circ} 33^{\prime} 54^{\prime \prime E}\right), 230 \mathrm{~m}$ alt., P-68-16-08, leg. Bakalin V.A. 16.X.2008 (VBGI), SAKHALIN PROV., «Wladimiroff», 123, leg. Faurie U. X.1907 (KYO), Vaida Mt. (4952'21"N 143²8'38"E), 947 m alt., S-32-17a-06, S-32-41-06, leg. Bakalin V.A. 20.VIII.2006 (VBGI), (4952'21"N $\left.143^{\circ} 28^{\prime} 38^{\prime \prime} \mathrm{E}\right), 950 \mathrm{~m}$ alt., S-32-20a-06, leg. Bakalin V.A. 20.VIII.2006 (VBGI).

\section{Porella grandiloba Lindb.}

JAPAN. AICHI PREF., Nukata-gun, 5861, leg. Takaki N. 3.VI.1949 (VBGI), GIFU PREF., Yoro-gun, 5316, leg. Takaki N. 21.XI.1948 (VBGI), HOKKAIDO PREF., Kushiro-gun, s.n, leg. Takida K. 18.VIII.1978 (VBGI), KYOTO PREF., Kibune (37007'18"N $\left.135^{\circ} 45^{\prime} 46^{\prime \prime E}\right)$ $300 \mathrm{~m}$ alt., J-3-26-14, leg. Bakalin V.A. 22.II.2014 (VBGI). REPUBLIC OF KOREA. JEOLLABUK PROV. (35²9'13"N 126 50'22"E), $250 \mathrm{~m}$ alt., Kor-13-09-11, leg. Bakalin V.A. 15.V.2011 (VBGI), GANGWON PROV. (3806'40"N 128²1'38"E), 580 m alt., 4273 , leg. Choi

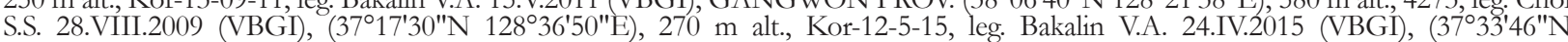

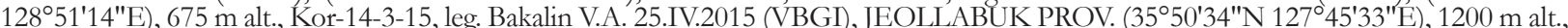
Kor-11-6-08, leg. Bakalin V.A. 26.VI.2008 (VBGI), (3549'53"N 12742'41"E), 720 m alt., Kor-14-32-08, leg. Bakalin V.A. 27.VI.2008 (VBGI), (3551 59"N $129^{\circ} 43^{\prime} 07^{\prime \prime E), ~} 690 \mathrm{~m}$ alt., Kor-17-50-08, leg. Bakalin V.A. 1.VII.2008 (VBGI), GYEONGNAM PROV. (35²1'15"N $\left.127^{\circ} 34^{\prime} 10^{\prime \prime E}\right), 760 \mathrm{~m}$ alt., Kor-16-6-09, leg. Bakalin V.A. 19.VI.2009 (VBGI), Seorak Mt. (38 07'40"N $\left.128^{\circ} 26^{\prime} 55^{\prime \prime} \mathrm{E}\right), 1250 \mathrm{~m}$ alt., Kor-7-2911, leg. Bakalin V.A. 11.V.2011 (VBGI), JEOLLABUK PROV. (35०46'57"N 129 42'46"E), 810 m alt., Kor-16-15-08, leg. Bakalin V.A.

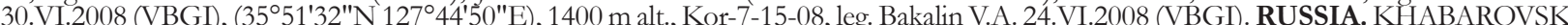
TERR., Anyui River (49²2'36"N 13743'11"E), 200 m alt., Kh-72-12-09, leg. Bakalin V.A. 21.IX.2009 (VBGI), Bolshekherhtsirsky State Nature Reserve, s.n., leg. Gambaryan S.K. s.d. (VBGI), Kazakevichevo Settl., s.n., leg. Gambaryan S.K. 24.VII.1975 (VBGI), Korfovskoye Settl., s.n., leg. Gambaryan S.K. s.d. (VBGI), s.n., leg. Gambaryan S.K. 18.VII.1975 (VBGI), PRIMORSKY TERR., Anisimovka Settl., s.n., leg. Bardunov L.V. 20.IX.1977 (VBGI), s.n., leg. Bardunov L.V. 20.IX.1977 (VBGI), Baranovskogo Miocene Volcano (4339'01"N $\left.131^{\circ} 55^{\prime} 02^{\prime \prime E}\right), 100 \mathrm{~m}$ alt., P-1-6-10, leg. Bakalin V.A. 18.V.2010 (VBGI), (433'07"N 131'55'10"E), 50 m alt., s.n., leg. Gorobets K.V. 12. VIII.2009 (VBGI), Bol'shekherhtsirsky State Nature Reserve, s.n., leg. Gambaryan S.K. 17.IX.1982 (VBGI), Bol'shoi Pelis Island, s.n., leg. Gambaryan S.K. 17.VII.1997 (VBGI), s.n., leg. Gambaryan S.K. 2.VII.1997 (VBGI), (4301'43"N 13301'24"E), 300 m alt., P-69-9-06, leg.

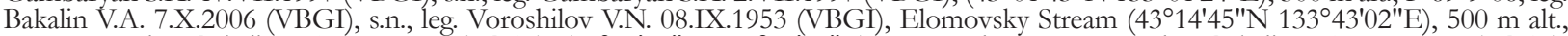
P-68-24-06, leg. Bakalin V.A. 6.X.2006 (VBGI), (4314'45"N 13343'02"E), $500 \mathrm{~m}$ alt., P-68-26-06, leg. Bakalin V.A. 6.X.2006 (VBGI),

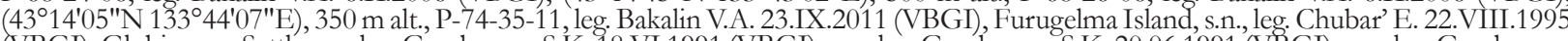
(VBGI), Glubinnoye Settl., s.n., leg. Gambaryan S.K. 18.VI.1991 (VBGI), s.n., leg. Gambaryan S.K. 20.06.1991 (VBGI), s.n., leg. Gambaryan S.K. 20.VI.1991 (VBGI), s.n., leg. Bakalin V.A. 19.VI.1991 (VBGI), Kedrovaya River (4305'34"N 131³1'18"E), 290 m alt., P-2-2-07, leg

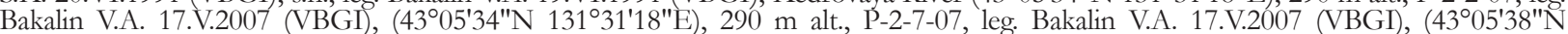
13130'35"E), $500 \mathrm{~m}$ alt., P-3-12-07, leg. Bakalin V.A. 18.V.2007 (VBGI), s.n., leg. Bakalin V.A. 13.VIII.1976 (VBGI), Kiy Bay (4302'00"N $\left.134^{\circ} 10^{\prime} 00^{\prime \prime E}\right), 40 \mathrm{~m}$ alt., s.n., leg. Cherdantseva V.Ya. 22.VIII.2007 (VBGI), Krasnoarmeisky District, s.n., leg. Gambaryan S.K. 18.VI.1991

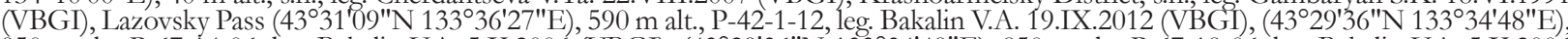
$850 \mathrm{~m}$ alt., P-67-14-06, leg. Bakalin V.A. 5.X.2006 (VBGI), (4329'36"N 133³4'48"E), 850 m alt., P-67-18-06, leg. Bakalin V.A. 5.X.2006 VBGI), Lazovsky State Nature Reserve, s.n., leg. Gambaryan S.K. X.1986 (VBGI), s.n., leg. Gambaryan S.K. 1.X.1986 (VBGI), s.n., leg. Gambaryan S.K. 22.VIII.1987 (VBGI), Litovka (Falaza) Mt. (4307'10"N 132 47'31"'E), 550 m alt., P-15-67-12, leg. Bakalin V.A. 25.VI.2012

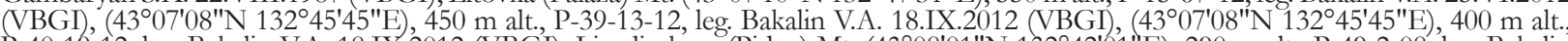
P-40-19-12, leg. Bakalin V.A. 18.IX.2012 (VBGI), Livadiyskaya (Pidan) Mt. (4308'01"N 13242'01"E), 290 m alt., P-49-2-08, leg. Bakalin

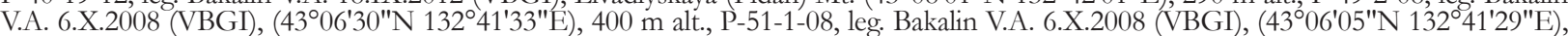
$440 \mathrm{~m}$ alt., P-52-4-08, leg. Bakalin V.A. 6.X.2008 (VBGI), Lozovyi Settl., s.n., leg. Voroshilov V.N. 28.IX.1953 (VBGI), Lozovyi (Chandolaz)

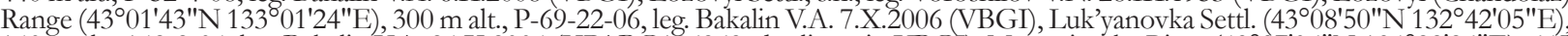
$140 \mathrm{~m}$ alt., 142-2-04, leg. Bakalin V.A. 24.X.2004 (KPABG106969, duplicate in VBGI), Margaritovka River (4337'06"N 134²2'26"E), 645 $\mathrm{m}$ alt., P-81-21-07, P-81-22-07, leg. Bakalin V.A. 20.IX.2007 (VBGI), Matveeva Island, s.n., leg. Gorobets K.V. 2.VII.1997 (VBGI), Milogradovka River $\left(43^{\circ} 27^{\prime} 00^{\prime \prime} \mathrm{N} 134^{\circ} 19^{\prime} 00^{\prime \prime E}\right), 340 \mathrm{~m}$ alt., s.n., leg. Cherdantseva V.Ya. 21.VIII.2007 (VBGI), Muravyova-Amurskogo

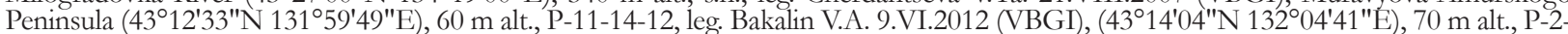
3-08, leg. Bakalin V.A. 14.VI.2008 (VBGI), (4314'04"N 132 04'41"E), $70 \mathrm{~m}$ alt., P-4-6-08, leg. Bakalin V.A. 14.VI.2008 (VBGI), s.n., leg. Gambaryan S.K. 08.V.1977 (VBGI), Olkhovaya Mt. (43²0'50"N 133 39'22"E), 1000 m alt., P-45-27-10, leg. Bakalin V.A. 11.IX.2010

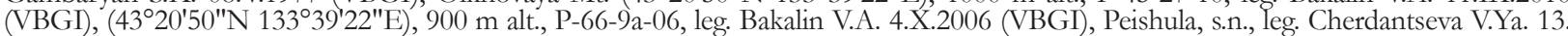
VII.1974 (VBGI), Popov Island, s.n., leg. Gambaryan S.K. 10.X.1979 (VBGI), s.n., leg. Gambarvan S.K. 5.VIII.1976 (VBGI), s.n., leg. Bardunov L.V. \& Cherdantseva V.Ya. 20.IX.1987 (VBGI), Pravava Sokolovka River (44002'00"N 134¹2'00"E), 600 m alt., \#07-559, leg. Ignatov M.S. 14.VIII.2007 (VBGI), Sinegornaya Pad' (4304'02"N 133³6'37"E), 230 m alt., P-73-23-11, leg. Bakalin V.A. 22.IX.2011

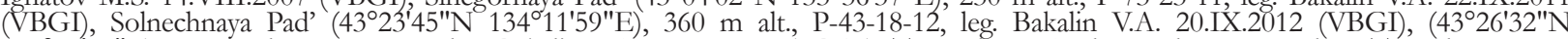
134¹3'20"E), $800 \mathrm{~m}$ alt., P-45-15-12, leg. Bakalin V.A. 21.IX.2012 (VBGI), Tsentralnove Settl., s.n., leg. Konovalova T. et al. 7.X.1995 (VBGI), Ussuriysky State Nature Reserve (4336'29"N 132¹4'59"E), $130 \mathrm{~m}$ alt., P-1-13-08, leg. Bakalin V.A. 28.V.2008 (VBGI), (4340'39"N $\left.132^{\circ} 29^{\prime} 06^{\prime \prime E}\right), 200 \mathrm{~m}$ alt., P-60-12-08, leg. Bakalin V.A. 14.X.2008 (VBGI), (4340'39"N 132 29'06"E), 200 m alt., P-60-14-08, leg. Bakalin V.A. 14.X.2008 (VBGI), (4341'50"N 132³3'19"E), $230 \mathrm{~m}$ alt., P-66-3-08, leg. Bakalin V.A. 16.X.2008 (VBGI), Yasnaya River, s.n., leg. Gambaryan S.K. 09.VII.1994 (VBGI), Yastrebovka Mt., 300 m alt., s.n., leg. Gambaryan S.K. 25.IX.1981 (VBGI), SAKHALIN PROV., «Kimonai», 119, leg. Faurie U. 21.IX.1908 (KYO), «Wladimiroff», 2, leg. Faurie U. X.1907 (KYO), Belaya River (47¹5'17"N 14248'47"E), $70 \mathrm{~m}$ alt., S-25-12-06, leg. Bakalin V.A. 12.VIII.2006 (VBGI), (47015'16"N 142 48'47"E), 70 m alt., S-25-18-06, leg. Bakalin V.A. 12. VIII.2006 (VBGI), Igrivaya River (46 $\left.26^{\prime} 58^{\prime \prime} \mathrm{N} 143^{\circ} 23^{\prime} 08^{\prime \prime} \mathrm{E}\right), 85 \mathrm{~m}$ alt., S-65-23-09, leg. Bakalin V.A. 16.IX.2009 (VBGI), Iturup Island $\left(45^{\circ} 20^{\prime} 02^{\prime \prime N} 148^{\circ} 37^{\prime} 04^{\prime \prime E}\right), 13 \mathrm{~m}$ alt., K-69-4-15, leg. Bakalin V.A. 9.IX.2015 (VBGI), (45¹9'51"N 148³7'35"E), 20 m alt., K-73-11a-15,

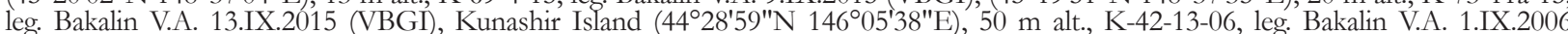
(VBGI), Mereya River (46³8'24"N 14254'05"E), 6 m alt., S-24-20-06, leg. Bakalin V.A. 11.VIII.2006 (VBGI), Nabil'sky Range (5046'00"N $143^{\circ} 16^{\prime} 58^{\prime \prime E}$ ), $800 \mathrm{~m}$ alt., S-29-11a-06, leg. Bakalin V.A. 16.VIII.2006 (VBGI), (5046'01"N 14316'58"E), 800 m alt., S-29-12a-06, leg.

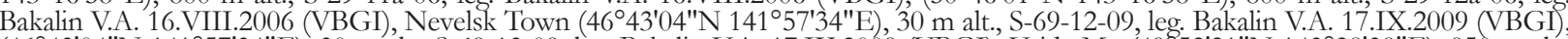

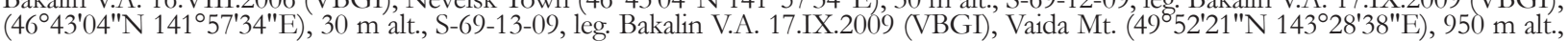


S-32-10-06, leg. Bakalin V.A. 20.VIII.2006 (VBGI), Yuzhno-Sakhalinst City area (4658'14"N 14247'27"E), $150 \mathrm{~m}$ alt., S-84-1-15, leg. Bakalin V.A. 23.IX.2015 (VBGI).

\section{Porella oblongifolia S. Hatt.}

JAPAN. AICHI PREF., Minamishitara-gun, $300 \mathrm{~m}$ alt., 30653, leg. Takaki N. 12.IX.1963 (VBGI), SAITAMA PREF., Chichibu Mts. 500 m alt., s.n., leg. Inoue H. 23.IV.1974 (VBGI), SHIGA PREF, Kanzaki-gun, 13552, leg. Takaki N. 5.V.1952 (VBGI), TOKYO PREF., Nishitama, Mt. Mitake (holotype of Porella oblongifolia), 9209, leg. Hattori S. 21.V.1941 (TNS-174590). REPUBLIC OF KOREA. JEOLLABUK PROV., Deokgyu Mts. (3549'53"N 127042'41"E), $724 \mathrm{~m}$ alt., Kor-14-22-08, leg. Bakalin V.A. 27.VI.2008 (VBGI). RUSSIA. PRIMORSKY

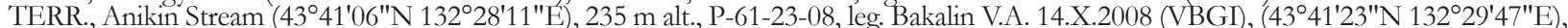

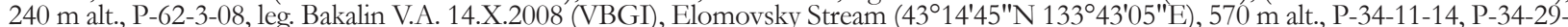
14, leg. Bakalin V.A. 10.IX.2014 (VBGI), (4314'45"N 133'43'02"E), 500 m alt., P-68-13-06, leg. Bakalin V.A. 6.X.2006 (VBGI), Lazovsky Pass (43⒉'36"N 13334'48"E), $850 \mathrm{~m}$ alt., P-67-23-06, leg. Bakalin V.A. 5.X.2006 (VBGI), Muravyova-Amurskogo Peninsula, s.n., leg. Voroshilov V.N. 4.VIII.1952 (VBGI), Ussuriysky State Nature Reserve (434ำ'23"N 132²9'47"E), $240 \mathrm{~m}$ alt., P-62-17-08, leg. Bakalin V.A. 14.X.2008 (VBGI), Yastrebovka Mt., s.n., leg. Gambaryan S.K. 25.IX.1981 (VBGI).

Porella obtusata var. macroloba (Steph.) S. Hatt. \& M.X. Zhang

RUSSIA. AMUR PROV., "Sergeevsky Utyos” Nature Monument (5041'27.2"N 127²0'17.1"E), 146 m alt., Am-63-5-18, leg. Krestov P.V. 22.IX.2018 (VBGI), Am-63-14-18 leg. Bakalin V.A. 22.IX.2018 (VBGI).

\section{Porella platyphylla (L.) Pfeiff.}

CHINA. INNER MONGOLIA PROV., Huang Gang Liang National Park (4331'15"N 117³1'12"E), 1690 m alt., China-31-8-10, leg.

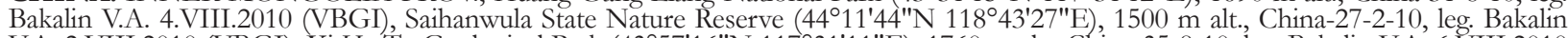

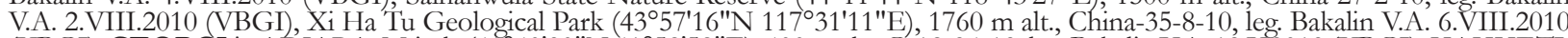
(VBGI). GEORGIA. ADJARA, Mtirala (41040'30"N 4152'58"E), $400 \mathrm{~m}$ alt., G-12-94-13, leg. Bakalin V.A. 12.V.2013 (VBGI), KAKHETI, Lagodekhi, s.n., leg. Tigishvili K. 24.VI.1978 (VBGI), MTIULETI Dusheti, s.n., leg. Gulmnaparashvili V. 2.V.1969 (VBGI), SVANETI Mestia, 1550 m alt., s.n., leg. Chikovani N. 2.III.1975 (VBGI). MOLDAVIA. STRASHENSKY DISTRICT, s.n., leg. Shabanova 22.VI.1956

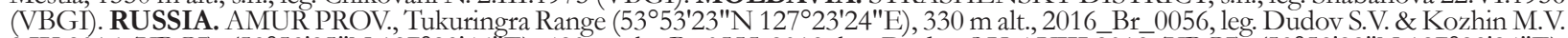

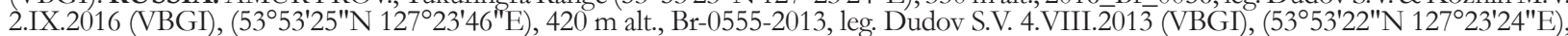

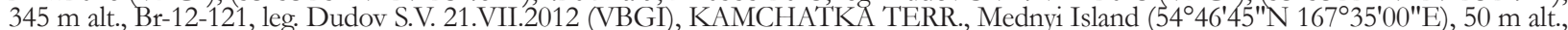

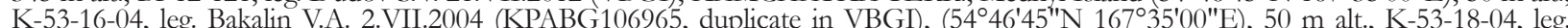
Bakalin V.A. 2.VII.2004 (KPABG106697), Anyui River (49²2'36"N 137 43'11"E), $200 \mathrm{~m}$ alt., Kh-72-3-09, leg. Bakalin V.A. 21.IX.2009 (VBGI), Komsomol'sky State Nature Reserve, s.n., leg. Cherdantseva V.Ya. 27.VI.1985 (VBGI), PRIMORSKY TERR., Dalnegorsk Town $\left(44^{\circ} 34^{\prime} 50^{\prime \prime} \mathrm{N} 135^{\circ} 32^{\prime} 58^{\prime \prime E}\right), 470 \mathrm{~m}$ alt., P-37-7-16, leg. Bakalin V.A. 26.VIII.2016 (VBGI), (44'35'12"N 135³3'24"E), 505 m alt., P-63-

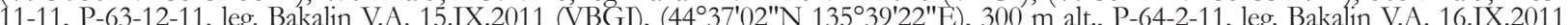
(VBGI), Gorbusha Settl., s.n., leg. Gambaryan S.K. 13.VII.1976 (VBGI), Lazovsky State Nature Reserve, s.n., leg. Gambaryan S.K.

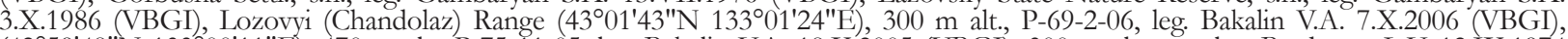
$\left(42^{\circ} 59^{\prime} 48^{\prime \prime N} 133^{\circ} 00^{\prime} 11^{\prime E}\right.$ ), $470 \mathrm{~m}$ alt., P-75-11-05, leg. Bakalin V.A. 18.X.2005 (VBGI), $300 \mathrm{~m}$ alt., s.n., leg. Bardunov L.V. 12.IX.1974

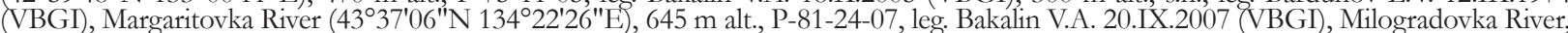

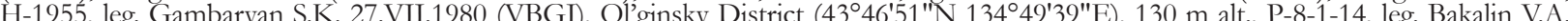
1.VII.2014 (VBGI), Pozharsky District, s.n., leg. Gambaryan S.K. 26.VI.1993 (VBGI), s.n., leg. Gambaryan S.K. 26.VI.1993 (VBGI), Sestra Mt., 213164, leg. Melick H. van 7.IX.2010 (VBGI), Sikhote-Alinsky State Nature Reserve, s.n., leg. Gambaryan S.K. 11.VII.1994 (VBGI),

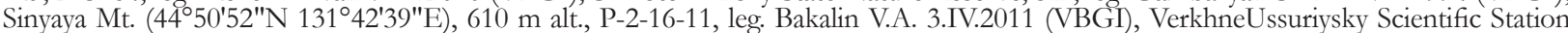

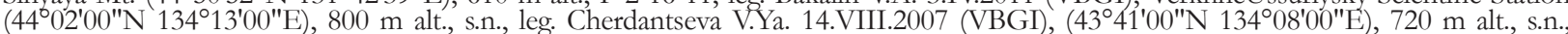
leg. Cherdantseva V.Ya. 19.VIII.2007 (VBGI), REP. OF ALTAI, Teletskove Lake, s.n., leg. Ionatov M.S. 24.VII.1991 (VBGI), REP. OF CRIMEA, Bakhchisaraisky District, s.n., leg. Belyanina N. et al. 23.V.1986 (VBGI), REP. OF DAGESTAN, Tsudakhar Settl. (42²0'01"N $\left.47^{\circ} 10^{\prime} 01 " \mathrm{E}\right), 1225 \mathrm{~m}$ alt., K20-1-11, leg. Konstantinova N.A. 6.IV.2011 (VBGI), REP. OF KARELIA, Segozero Lake, s.n., leg. Savicz L.I. 3.VIII.1921 (VBGI), STAVROPOLSKY TERR., Kislovodsk City (4353'59"N 4245'28"E), $1160 \mathrm{~m}$ alt., s.n., leg. Dulin M.V. 17.XII.2015 (VBGI). SWITZERLAND. CANTON OF VALAIS, Follatères (460.'26"N 704'36"E), $500 \mathrm{~m}$ alt., Switzerland-49-7-13, leg. Bakalin V.A. 28.IX.2013 (VBGI). U.S.A. CALIFORNIA, Lake Co., s.n., leg. Shevock J.R. 3.VII.1997 (MO5362027).

Porella spinulosa (Steph.) S.Hatt.

JAPAN. NIIGATA PREF., Sado Island, s.n., leg. Homma K. 05.I.1980 (NICH-235052), TOKYO PREF., Takao (holotype of Madotheca spinulosa Steph.), 42, leg. Sakurai 4.IV.1909 (G00048036/21884, G). RUSSIA. PRIMORSKY TERR., Elomovsky Stream (43¹4'45"N $\left.133^{\circ} 43^{\prime} 02^{\prime \prime E}\right), 500 \mathrm{~m}$ alt., P-68-37-06, leg. Bakalin V.A. 6.X.2006 (VBGI).

Porella ulophylla (Steph.) S.Hatt.

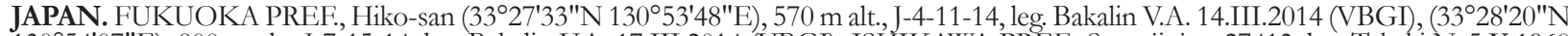
$130^{\circ} 54^{\prime} 07^{\prime \prime E}$ ), $800 \mathrm{~m}$ alt., J-7-15-14, leg. Bakalin V.A. 17.III.2014 (VBGI), ISHIKAWA PREF., Suzu-jinjya, 27413, leg. Takaki N. 5.X.1960 (VBGI), IWATE PREF., Chateau de Morioka (isotype of Madotheca ulophylla Steph.), 15034, leg. Faurie U. XI.1894 (KYO), OITA PREF.,

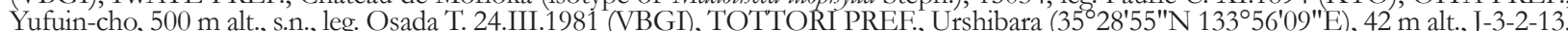
leg. Bakalin V.A. 11 III. 2013 VBGD. REPUBLIC OF KOREA. JEONNAM PROV. (3443'17"N 126 51'45"E) $150 \mathrm{~m}$ alt., Kor-22-13-

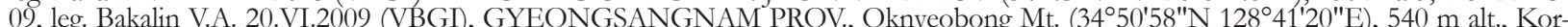
44-12-14, leg. Bakalin V.A. 7.XII.2014 (VBGI), (3451'38"N 128 32'25"E), 360 m alt., Ror-43-3-14, leg. Bakalin V.A. 6.XII.2014 (VBGI), JEONNAM PROV., Kumsan Mt. (3445'08'N 127 58'57"E), $636 \mathrm{~m}$ alt., Kor-22-16-11, leg. Bakalin V.A. 21.V.2011 (VBGI), Oinarodo Island $\left(34^{\circ} 26^{\prime} 09^{\prime \prime} \mathrm{N} 127^{\circ} 30^{\prime} 21^{\prime \prime E}\right), 413 \mathrm{~m}$ alt., Kor-18-28-11, leg. Bakalin V.A. 20.V.2011 (VBGI, GYEONGNAM PROV., (35⒈'45"N $\left.127^{\circ} 42^{\prime} 51 " E\right), 1700 \mathrm{~m}$ alt., Kor-26-9-15, leg. Bakalin V.A. 6.V.2015 (VBGI). RUSSIA. AMUR PROV., Khingansky Reserve $\left(49^{\circ} 01^{\prime} \mathrm{N}\right.$ $\left.130^{\circ} 27^{\prime} \mathrm{E}\right)$, s.n., leg. Gambaryan S.K. 16.VII. 1991 (VBGI), Tukuringra Range $\left(54^{\circ} 03^{\prime} 44^{\prime \prime N} 127^{\circ} 21^{\prime} 23^{\prime \prime} \mathrm{E}\right), 465 \mathrm{~m}$ alt., 2014_Br_0191, leg. Dudov S.V. 15.VIII.2014 (VBGI), (54 15'45"N 126 50'53"E), 340 m alt., Br-12-015, leg. Dudov S.V. 26.VII.2012 (VBGI), KHABAROVSK

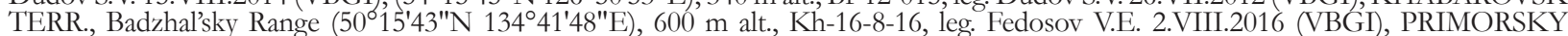

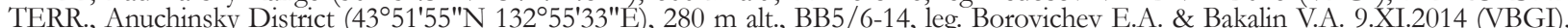

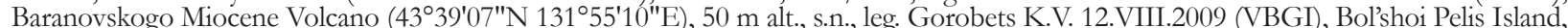

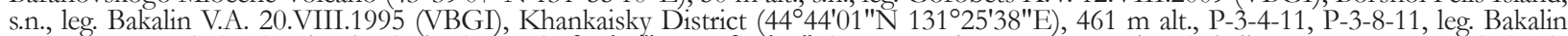

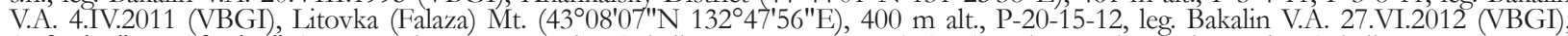
$\left(43^{\circ} 07^{\prime} 08^{\prime \prime N} 132^{\circ} 45^{\prime} 45^{\prime \prime} \mathrm{E}\right), 400 \mathrm{~m}$ alt., P-40-2-12, leg. Bakalin V.A. 18.IX.2012 (VBGD), Luk'yanovka Settl., s.n., leg. Bakalin V.A. 24.X.2004 (KPABG106968, duplicate in VBGI), Margaritovka River (43.37'06"N 134 22'26"E), $645 \mathrm{~m}$ alt, P-81-15-07, leo. Bakalin VA. 20.IX 2007

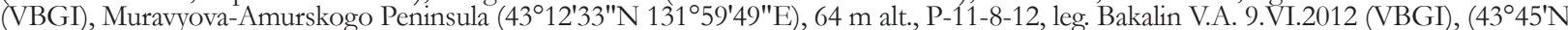

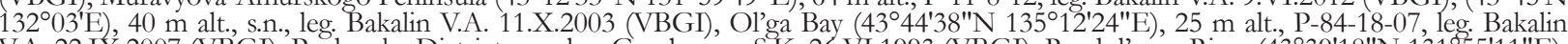

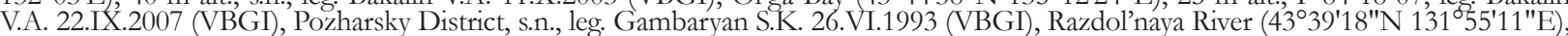
$20 \mathrm{~m}$ alt., Prim-18-2-16, leg. Klimova K.G. \& Bakalin V.A. 16.X.2016 (VBGI), Stenina Island, s.n. leo Bakalin V.A. 7VI1996 (VBGI), Vladivostok City, s.n., leg. Bakalin V.A. 11.X.2003 (KPABG105683, duplicate in VBGI), s.n., leg. Bakalin V.A. 11.X.2003 (KPABG105679, duplicate in VBGI). 


\section{Porella vernicosa Lindb.}

JAPAN. AICHI PREF., Kitashitara-gun, 10750, leg. Takaki N. 2.IX.1951 (VBGI), FUKUOKA PREF., Hiko-san (3328'20"N 13054'07"E), $800 \mathrm{~m}$ alt. J-7-14-14, leg. Bakalin V.A. 17.III.2014 (VBGI), Tagama-gun (3328'49"N 13056'04"E), $1000 \mathrm{~m}$ alt., J-6-1-14, leg. Bakalin V.A.' 16.III.2014 (VBGI), ISHIKAIWA PREF., Suzu-shi, $170 \mathrm{~m}$ alt., 27350, leg. Takaki N. 5.X.1960 (VBGI), KOCHI PREF. Tosa-gun (334 47'28"N $\left.133^{\circ} 27^{\prime} 40^{\prime \prime E}\right), 360 \mathrm{~m}$ alt., J-6-13-15, leg. Bakalin V.A. 24.III.2015 (VBGI), NAGANO PREF., Shimoina-gun (3534'07"N 138 07'05"E), $1450 \mathrm{~m}$ alt., 35591 , leg. Yamaguchi T. 11 .VIII.2015 (VBGI), SHIZUOKA PREF., Tagata-gun (3450'02"N $138^{\circ} 55^{\prime} 56^{\prime \prime} \mathrm{E}$ ), $700 \mathrm{~m}$ alt., s.n., leg. Higuchi M. 19.III.2001 (VBGI). REPUBLIC OF KOREA. JEONNAM PROV. (34²43'17"N 126 $\left.51^{\prime} 45^{\prime \prime E}\right), 150$ m alt., Kor-22-8-09, leg. Bakalin V.A. 20.VI.2009 (VBGI) GANGWON PROV. (37³5'12"N 128 53'52"E), 1055 m alt., Kor-16-8-15, leg. Bakalin V.A. 25.IV.2015 (VBGI), (37²2'37"N 12837'38"E), 400 m alt., Kor-21-7-15, leg. Bakalin V.A. 26.IV.2015 (VBGI), JEONNAM PROV., Duryunbong Mt.

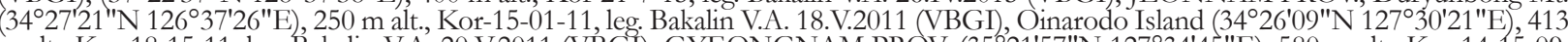
$\mathrm{m}$ alt., Kor-18-15-11, leg. Bakalin V.A. 20.V.2011 (VBGI), GYEONGNAM PROV. (35²1'57"N 127³4'45"E), 580 m alt., Kor-14-15-09, leg. Bakalin V.A. 19.VI.2009 (VBGI). RUSSIA. KHABAROVSK TERR. Anvui River (49²2'36"N 13743'11"'E), 200 m alt. Kh-72-4-09, leg. Bakalin V.A. 21 IX 2009 (VBGI), Badzhal'sky Range (50¹5'43"N 13441'48"E), 600 m alt. Kh-16-10-16, leg. Bakalin V.A. 2 VIII.2016 (VBGI), (50¹5'06"N 134²0'26"E), $585 \mathrm{~m}$ alt., Kh-31-14-16, leg. Bakalin V.A. 14.VIII.2016 (VBGI), (50¹6'52"N 134²4'45"E), $570 \mathrm{~m}$ alt., Kh-31-14-16, leg. Bakalin V.A. 30.VII.2016 (VBGI), Korfovskoe Settl., s.n., leg. Fedchenko B.A. 1.IX.1909 (VBGI), Tardoki-Yani Range (484'43"N 138 05'44"E), 620 m alt., Kh-45-43-13, leg. Bakalin V.A. 28.VIII.2013 (VBGI), PRIMORSKY TERR., Anuchinsky District

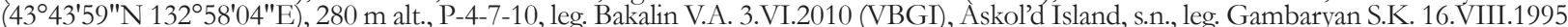
(VBGI), Avvakumovka River (4351'42"N 134⒌'35"E), $160 \mathrm{~m}$ alt., P-85-5-07, leg. Bakalin V.A. 22.IX.2007 (VBGI), Barabash-Levada

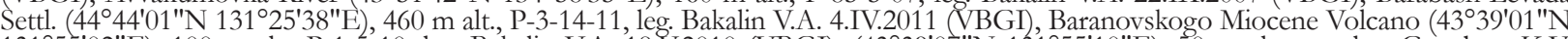
$\left.131^{\circ} 55^{\prime} 02^{\prime \prime E}\right), 100 \mathrm{~m}$ alt., P-1-5-10, leg. Bakalin V.A. 18.V.2010 (VBGI), (433ำ $\left.07^{\circ} \mathrm{N} 131^{\circ} 55^{\prime} 10^{\prime \prime} \mathrm{E}\right), 50 \mathrm{~m}$ alt., s.n., leg. Gorobets K.V.

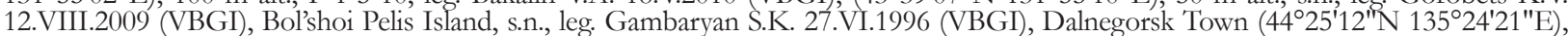

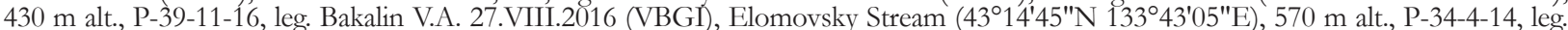

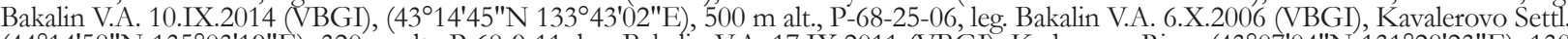

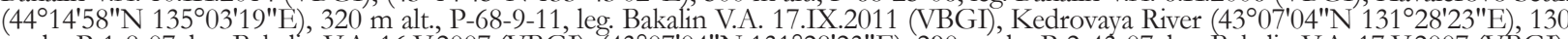

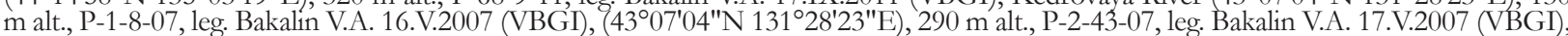
s.n. leg. Vasilieva L.N. 12.X.1964 (VBGI) Kravtsovka Village (43⒉'06"N 13138'18"E), 120 m alt. Prim-19-10-16, leg. Klimova K.G.

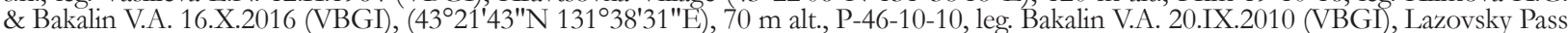

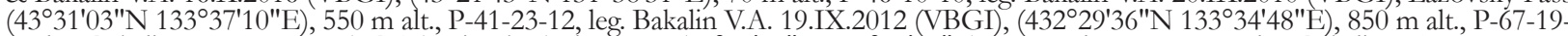
06, leg. Bakalin V.A. 5.X.2006 (VBGI), Litovka (Falaza) Mt. (43007'08"N 13245'45"E), $400 \mathrm{~m}$ alt., P-40-23-12, leg. Bakalin V.A. 18. IX.2012

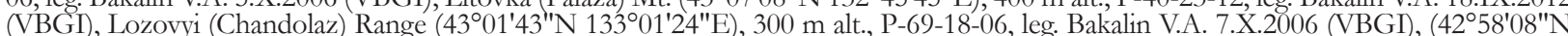
$133^{\circ} 02^{\prime} 41^{\prime \prime E}$, $150 \mathrm{~m}$ alt. P-76-14-05, leg. Bakalin V.A. 19.X.2005 (VBGD, Luk'vanovka Settl. (430'ㄷㅇ"N 132 42'05"E), $140 \mathrm{~m}$ alt., 142 6-04, leg. Bakalin V.A. 24.X.2004 (KPABG106974, duplicate in VBGI), Margaritovka River (433'06"N 134²2'26"E), 645 m alt., P-8126-07, leg. Bakalin V.A. 20.IX.2007 (VBGI), Muravyova-Amurskogo Peninsula (43¹4'04"N 132 04'41"E), 70 m alt., P-4-5-08, leg. Bakalin V.A. 14.VI.2008 (VBGI), s.n., leg. Gambaryan S.K. 8.V.1977 (VBGI), Olkhovaya Mt. (43²0'50"N 13339'22"E), 1500 m alt., P-65-8a-06 leg. Bakalin V.A. 3.X.2006 (VBGI), (4320'50"N 13339'22"E), 900 m alt., P-66-22-06, leg. Bakalin V.A. 4.X.2006 (VBGI), Povorotnava Pad'

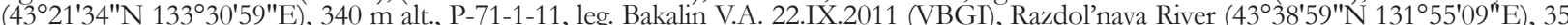
$m$ alt., Prim-17-2-16, leg. Klimova K.G. \& Bakalin V.A. 16.X.2016 (VBGI), Rikorda Island, s.n., leg. Gambaryan S.K. 3.VIII.1995 (VBGI),

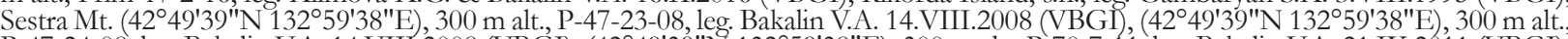
P-47-24-08, leg. Bakalin V.A. 14.VIII.2008 (VBGI), (42049'39"N 13259'38"E), $300 \mathrm{~m}$ alt., P-70-7-11, leg. Bakalin V.A. 21.IX.2011 (VBGI), Sikhote-Alinsky State Nature Reserve, s.n., leg. Doronina Yu.A. 14.VIII.1976 (VBGI), s.n., leg. Shemetova N.S. 16.VII.1961 (VBGI), s.n., leg. Doronina Yu.A. 13.VIII.1976 (VBGI), s.n., leg. Shemetova N.S. 30.IX.1956 (VBGI), s.n., leg. Flyagina I.A. 15.VI.1979 (VBGI), s.n., leg. Shemetova N.S. 21.VI.1960 (VBGI), Sinyaya Mt. (4450'52"N 131 42'39"E), $610 \mathrm{~m}$ alt., P-2-18-11, leg. Bakalin V.A. 3.IV.2011

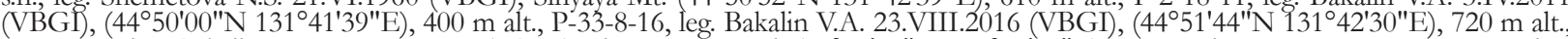
P-33-8-16, leg. Bakalin V.A. 24.VIII.2016 (VBGI), Sinegornava Pad' (430. $4^{\prime} 02^{\prime \prime N} 133^{\circ} 36^{\prime} 37^{\prime \prime E}$ ), $230 \mathrm{~m}$ alt., P-73-21-11, P-73-26-11, leg.

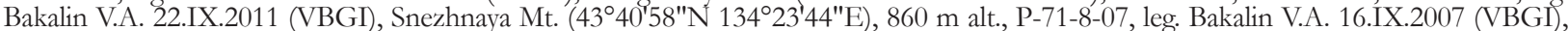
$\left(43^{\circ} 43^{\prime} 33^{\prime \prime} \mathrm{N} 134^{\circ} 27^{\prime} 23^{\prime \prime E}\right), 780 \mathrm{~m}$ alt., P-77-9-07, leg. Bakalin V.A. 18.IX.2007 (VBGI), (433ํ'05"N 134²0'54"E), 720 m alt., P-79-1-07,

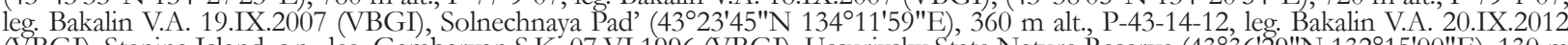
(VBGI), Stenina Island, s.n., leg. Gambaryan S.K. 07.VI.1996 (VBGI), Ussuriysky State Nature Reserve (4336'29"N $\left.132^{\circ} 15^{\prime} 00^{\prime \prime} \mathrm{E}\right), 130 \mathrm{~m}$

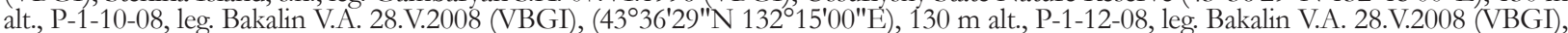

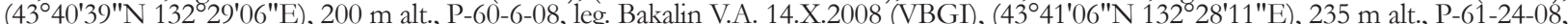

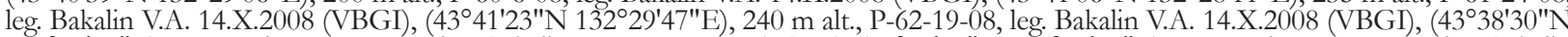
$\left.132^{\circ} 33^{\prime} 16^{\prime \prime E}\right), 330 \mathrm{~m}$ alt., P-63-12-08, leg. Bakalin V.A. 15.X.2008 (VBGI), (4341'33"N 132³3'52"E), $230 \mathrm{~m}$ alt., P-68-22-08, leg. Bakalin V.A. 16.X.2008 (VBGI), s.n., leg. Gambaryan S.K. 25.IX.1986 (VBGI), s.n., leg. Komarov V.L. 17.VIII.1930 (VBGI), Verkhne-Ussuriysky Scientific Station, s.n., leg. Gambarvan S.K. 20.IX.1979 (VBGI), Vladivostok City (4312'33"N 13159'49"E), 60 m alt., P-11-1-12, leg.

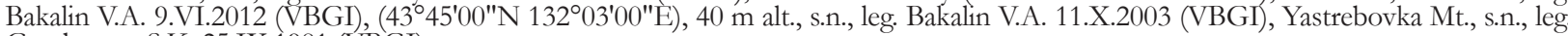
Gambaryan S.K. 25.IX.1981 (VBGI)

\section{N D E X}

(accepted names of treated taxa are in bold italic, accepted names of not treated taxa are in regular and synonyms are in italic).

Ascidiota blepharophylla C. Massal. - 2, 3,23

Jungermannia platyphylla L. - 16 Macvicaria ulophylla (Steph.) S. Hatt. -20

Madotheca caespitans Steph. -5

Madotheca chinensis Steph. - 6, 7, 24

Madotheca densifolia Steph. -8

Madotheca faurieri Steph. -8

Madotheca macroloba Steph. - 14

Madotheca platyphylla (L.) Dumort. - 16

Madotheca spinulosa Steph. - 18, 26

Madotheca ulophylla Steph. - 20, 26

Madotheca urogea C. Massal. - 10

Madotheca ussuriensis Steph. - 1, 10

Porella arboris-vitae (With.) Grolle - 2, 4, 5

Porella baueri (Schiffn.) C.E.O.Jensen - 2, 4

Porella caespitans (Steph.) S.Hatt. - 3, 4, 5, 21, 23

Porella caespitans var. setigera (Steph.) S. Hatt. -5

Porella chinensis (Steph.) S.Hatt. - 4, 6, 7, 24

Porella cordaeana (Huebener) Moore - 13, 17, 22, 24

Porella decurrens (Steph.) Parihar -22

Porella densifolia (Steph.) S.Hatt. - 4, 5, 7, 8, 22, 24

Porella faurieri (Steph.) S.Hatt. - 4, 8, 9, 10, 13, 21, 22, 24

Porella gracillima Mitt. - 1, 4, 5, 9, 10, 11, 14, 16, 22, 24
Porella gracillima subsp. urogea (C. Massal.) S. Hatt. \& M.X. Zhang $-10$

Porella gracillima var. urogea (C. Massal.) S. Hatt. - 10

Porella grandiloba Lindb. - 1, 5, 11, 12, 13, 16, 25

Porella macroloba (Steph.) S. Hatt. \& Inoue -14

Porella nitens (Steph.) S. Hatt. - 14, 22

Porella nitidula (C. Massal.) S. Hatt. - 22

Porella oblongifolia S. Hatt. - 4, 12, 13, 14, 15, 25

Porella obtusata fo. macroloba (Steph.) S. Hatt. -14

Porella obtusata var. macroloba (Steph.) S. Hatt. et M.X. Zhang $-1,5,6,14,15,22,26$

Porella platyphylla (L.) Pfeiff. - 4, 7, 8, 16, 17, 18, 20, 22, 26

Porella setigera (Stephani) S. Hatt. -5

Porella spinulosa (Steph.) S.Hatt. - 4, 18, 19, 20, 26

Porella tenera H. Hara - 22

Porella thuja fo. macroloba (Steph.) S. Hatt. - 14

Porella tosana (Steph.) S. Hatt. - 5, 22

Porella ulophylla (Steph.) S.Hatt. - 4, 19, 20, 22, 26

Porella urogea (C. Massal.) P.C. Chen. - 10

Porella vernicosa fo. spinulosa (Steph.) S. Hatt. - 18

Porella vernicosa Lindb. 4, 19, 21, 26

Porella vernicosa subsp. fauriei (Steph.) M. Hara. - 8 